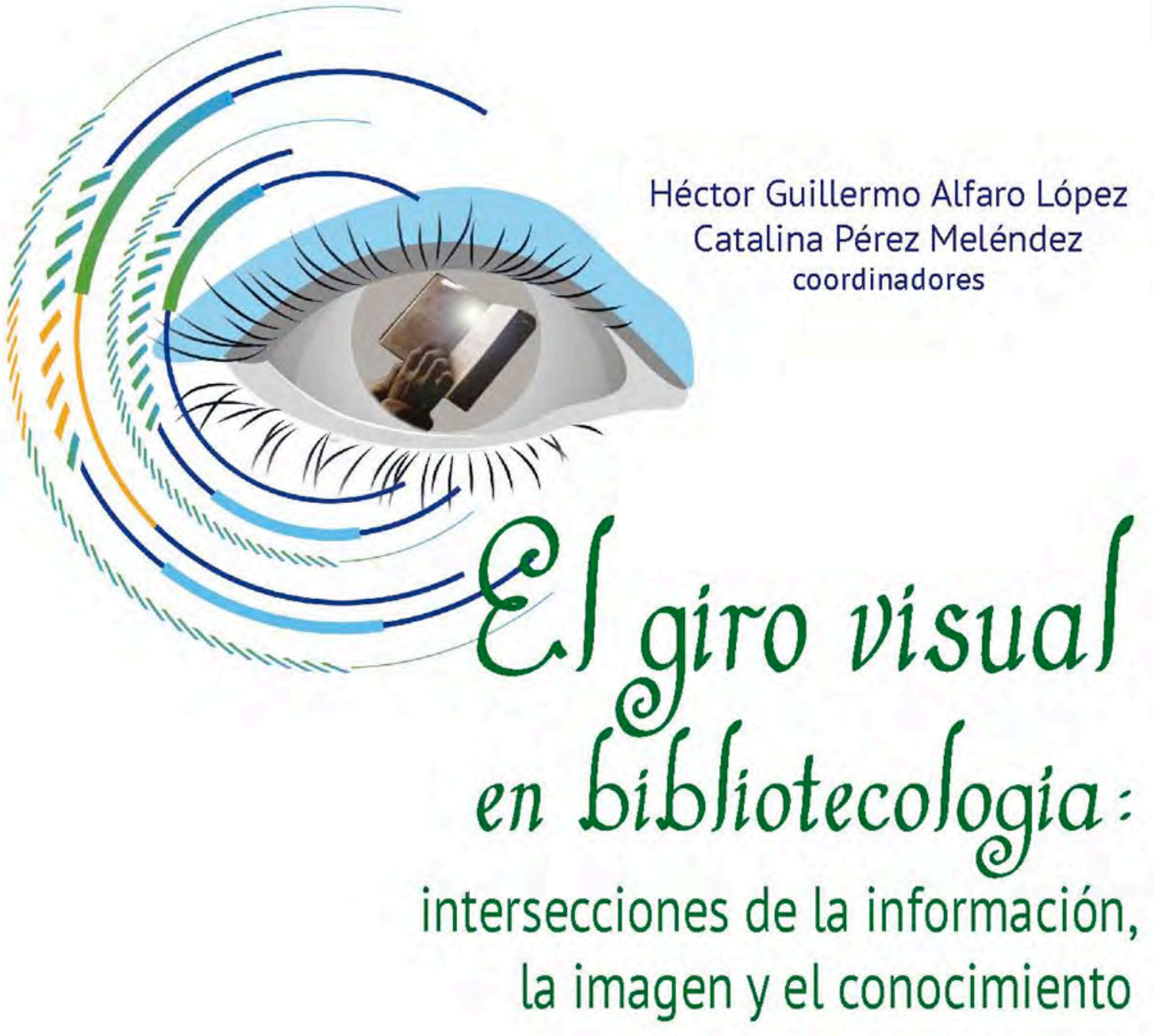




\section{La presente obra está bajo una licencia de:}

\section{http://creativecommons.org/licenses/by-nc-sa/3.0/deed.es MX}

\section{Atribución-No Comercial-Licenciamiento Reciproco 3.0 Unported}

Eres libre de:

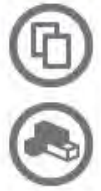

copiar, distribuir y comunicar públicamente la obra

hacer obras derivadas

Bajo las condiciones siguientes:

Atribución - Debes reconocer la autoría de la obra en los términos

especificados por el propio autor o licenciante.

No comercial - No puedes utilizar esta obra para fines comerciales.

Licenciamiento Recíproco - Si alteras, transformas o creas una obra a

partir de esta obra, solo podrás distribuir la obra resultante bajo una licencia

igual a ésta.

\section{Esto es un resumen fácilmente legible del: texto legal (de la licencia completa)}

En los casos que sea usada la presente obra, deben respetarse los términos especificados en esta licencia.
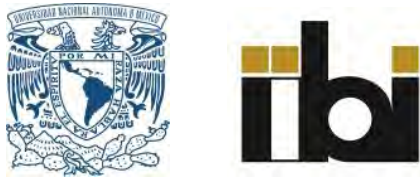
El giro visual en bibliotecología:

intersecciones de la información,

la imagen y el conocimiento 


\title{
El giro visual en bibliotecología: intersecciones de la información, la imagen y el conocimiento
}

\author{
Coordinadores \\ Héctor Guillermo Alfaro López \\ Catalina Pérez Meléndez
}

\section{Universidad Nacional Autónoma de México} 2014 


\section{N370}

G57

El giro visual en bibliotecología : intersecciones de la información, la imagen y el conocimiento / coordinadores Héctor Guillermo Alfaro López, Catalina Pérez Meléndez.-- México : UNAM, Instituto de Investigaciones Bibliotecológicas y de la Información, 2014.

vii, 152 p. -- (Pensamiento teórico bibliotecológico)

ISBN: 978-607-02-6109-1

1. Interpretación de la Imagen 2. Bibliotecología -Estudio -- Imágenes 3. Comunicación Visual

I. Alfaro López, Héctor Guillermo, coordinador II.

Pérez Meléndez, Catalina, coordinadora III. ser.

Diseño de la portada: Editorial Albatros

Primera edición 2014

DR (C) Universidad Nacional Autónoma de México

Ciudad Universitaria, 04510, México D.F.

Impreso y hecho en México

ISBN: 978-607-02-6109-1 


\section{Contenido}

Presentación $\ldots \ldots \ldots \ldots \ldots \ldots \ldots \ldots \ldots \ldots \ldots \ldots \ldots \ldots \ldots \ldots \ldots \ldots$ Héctor Guillermo Alfaro López

\section{Imagen y desacralización del libro y la biblioteca}

PRESENTACIÓN

Leonor García Urbano

ECLIPSE DEL LIBRO SACRALIZADO: AVATARES DEL TEXTO Y LA IMAGEN ........... 7 Héctor Guillermo Alfaro López

LOS MODOS DE LEER Y VER A PROPÓSITO DE LA IMAGEN

Y SU ESCRITURA

Minerva Anguiano González

LAS PERIPECIAS DE LA IMAGEN: SU INSERCIÓN EN LA BIBLIOTECOLOGÍA

Jonathan Hernández Pérez

\section{Intervenciones visuales sobre el concepto libro y biblioteca}

PRESENTACIÓN

53

Jennifer Voutssás Lara

LAS LECTORAS A TRAVÉS DEL ESPEJO:

EL DISCURSO DE LA LECTURA EN IMÁGENES

Graciela Leticia Raya Alonso

EL MAPA CUENTA UNA IMAGEN 


\section{Relaciones entre la cultura escrita y la cultura visual}

PRESENTACIÓN

93

Emilio Ramírez Cravo

HACIA UNA LECTURA ESTRUCTURADA

DE LA OBRA CINEMATOGRÁFICA: EL OJO DEL HURACÁN

95

Luis Raúl Iturbe Fuentes

¿DÓNDE Y CÓMO MORIRÁN LOS LIBROS? LA OBRA RÉQUIEM.

117

Emilio Chapela Pérez

EL PEREGRINAJE TEXTUAL DE LA IMAGEN: LA INTERMEDIACIÓN

DEL LENGUAJE DOCUMENTAL Y LAS DISTORSIONES COGNITIVAS

Catalina Pérez Meléndez

Epílogo

151

Catalina Pérez Meléndez 


\section{Presentación}

T as imágenes en la actualidad son parte infaltable del paisaje cotidiano de individuos y sociedades. La vida de las personas -tanto en la esfera consciente como inconsciente- se encuentra signada por la influencia de imágenes; las diversas estructuras sociales transitan por la presencia de un amplio espectro de imágenes que marcan su organización y orientación. A ello, ha contribuido la aparición de varios dispositivos productores de imágenes, que a lo largo del siglo xx se perfeccionaron y desarrollaron, como la fotografía y el cine, así como en el ocaso de dicha centuria, el dispositivo digital. Lo anterior, da lugar a un amplio espectro de tipos de imágenes; que van desde lo cultural a lo científico, de lo social a lo artístico, lo cual, pone de manifiesto que parte importante de la información y el conocimiento se generan y expresan por la vía de las imágenes, provocando que varías ciencias se avoquen al estudio sistemático del universo de éstas.

Como no podía ser de otra manera, para la Bibliotecología y las Ciencias de la Información el estudio de las imágenes se 
convierte en importante objeto de conocimiento; que, cabe senalar, se abre paso entre las diversas manifestaciones del que ha sido objeto privilegiado de tales ciencias para el pleno reconocimiento de su estatuto cognoscitivo: la información textual.

De ahí que para contribuir al reconocimiento de la imagen como objeto de conocimiento bibliotecológico, el Seminario de Investigación Pensamiento Teórico Bibliotecológico (SPTB), adscrito al Instituto de Investigaciones Bibliotecológicas y de la Información, se ha enfocado a la indagación epistemológica de diversas expresiones y perspectivas de las imágenes. Y, como parte y extensión de este proyecto grupal de investigación, el SPTB organizó el Primer Seminario: El giro visual en bibliotecología: intersecciones de la información, la imagen y el conocimiento, para dar a conocer entre la comunidad bibliotecológica e interesados en el tema los trabajos pertenecientes a la investigación de los integrantes del susodicho Seminario, así como de las propuestas que llevan a cabo algunos otros especialistas provenientes de diversas instituciones académicas.

Este libro no sólo es el testimonio de los trabajos presentados en el evento, sino también del entusiasmo cognoscitivo, no exento de fascinación y fulgor lúdico, por las imágenes de todos aquellos que de una u otra forma colaboraron en su realización.

Así, de manera especial deseo externar un agradecimiento a la co-coordinadora del evento como de la edición de la memoria emanada de él, Catalina Pérez Meléndez, por su visión e incansable empeño en la realización de los mismos. Asimismo, extiendo el agradecimiento a Graciela Leticia Raya Alonso, por el generoso e irrestricto apoyo que brindó a los coordinadores.

Héctor Guillermo Alfaro López 


\section{IMAGEN Y DESACRALIZACIÓN DEL LIBRO Y LA BIBLIOTECA}




\title{
Presentación
}

\author{
LEONOR GARCÍA URBANO \\ Centro de Investigaciones Interdisciplinarias \\ en Ciencias y Humanidades de la UNAM
}

\begin{abstract}
A 1 meditar sobre el eje temático de esta mesa, recordé cierta novela histórica de suspenso publicada en 1981, que evoca el ambiente religioso de una abadía italiana del siglo XIV. La novela trata sobre la investigación que realizan fray Guillermo de Baskerville y su pupilo Adso de Melk, alrededor de la misteriosa serie de crímenes perpetrados en el monasterio benedictino. Para quienes tuvieron la oportunidad de leer la novela o ver la versión cinematográfica, dirigida por el francés Jean-Jacques Annaud en 1986, seguramente ya habrán recordado que se trata de El Nombre de la Rosa escrita por Umberto Eco. Esta obra no sólo brinda la oportunidad de seguir la trama detectivesca en la que finalmente se esclarecen los crímenes de la abadía, también permite evocar la época portentosa de los monasterios, el estilo de vida de sus habitantes, al interior y exterior de sus edificaciones y, por supuesto, las ideas y sentimientos que fluyen en torno a los conflictos religiosos.
\end{abstract}


Durante una entrevista $^{1}$ realizada en el 2006, a propósito del vigésimo quinto aniversario de la obra de Umberto Eco. El autor confiesa que antes de escribir su novela dejó pasar un año sin escribir una sola línea, tiempo que dedicó a leer y dibujar cientos de laberintos y plantas de abadías, además de abocetar sus personajes porque necesitaba reconocerlos y familiarizarse con ellos antes de hacerlos hablar y actuar, de ese modo realizó los bocetos de su mundo literario. Así, Umberto Eco nos comparte que sus novelas nunca empezaron a partir de un proyecto, sino de una imagen. Recuerda entonces que en la imagen primigenia que impulsó la escritura de su obra, se veía a sí mismo en la Abadía de Santa Escolástica, frente a un atril enorme donde leía las Acta Sanctorum, divirtiéndose como un loco. De ahí le había surgido la idea de imaginar a un benedictino en un monasterio que, mientras leía la versión encuadernada del manifiesto, moría fulminado. Con gran sentido del humor Umberto Eco tuvo la experiencia de descubrir, en una edad madura, aquello sobre lo que no podía teorizar porque la fuerza de la imagen sólo podía abrirle las puertas de la narración.

Tomando en cuenta la idea de John Berger, sobre "las imágenes se hicieron al principio para evocar la apariencia de algo ausente", ${ }^{2}$ es factible comprender por qué Umberto Eco se dio a la tarea de "recuperar" de su mente las imágenes que poblarían el mundo literario de su obra. Los dibujos, que por cierto se negó a vender a una biblioteca estadounidense, se convirtieron, como diría Minerva Anguiano, en la "evidencia" y despliegue de la imagen (mental), la cual, permitió la construcción de otra imagen (la del documento) y que por más de

1 Antonio Gnoli, Entrevista a Umberto Eco. Y así le puse el nombre de la rosa, 26 de agosto de 2006.

2 John Berger, Modos de ver, p. 6. 
tres décadas ha alimentado el imaginario colectivo de sus lectores. Demostrando, como comenta Guillermo Alfaro, parafraseando a Herbert Read, "de manera incuestionable la imagen precede a la palabra", 3 que el impulso primario a través del cual desembocan las imágenes, es el elán vital del autor. Umberto Eco precisa sobre la cita de la rosa, referida en el título de su obra; significa que cuando las cosas dejan de existir sólo quedan las palabras. Pero si pensamos en el libro como contenedor de imágenes (composición literaria) e imagen en sí (composición física), valdría la pena considerar, como Jonathan Hernández indica, a propósito de la composición física, si después o a pesar de las palabras de la obra, el áurea de las imágenes en la cubierta de las respectivas versiones, literaria y cinematográfica, ha logrado permear en el imaginario colectivo, sobreviviendo a los hechos pasados y a las mismas palabras.

Independientemente de la abundante información que en la novela y, sobre ella, se nos pueda ofrecer, he querido rescatar esta obra porque ilumina en sí un mundo insospechadamente activo, refugio de la cultura y del conocimiento. Porque al entrar a esos espacios, amplios y místicos lugares de resguardado del material librario, pudiéramos con un poquito de imaginación y con otro más de empeño, comenzar a oler las tintas combinadas con los aromas del pergamino y de la madera, escuchar a los amanuenses acomodándose en sus lugares o trasladando el material de su trabajo al scriptorium. Y escuchar la indicación abrupta del bibliotecario a cargo, pidiendo silencio para comenzar a trabajar. Al final, podríamos imaginar, por qué no, el silencio necesario que requiere la creación. Acompañando al escribano apreciaríamos mejor el arte de su composición, porque la producción no sólo llegó a configurarse a partir de un

3 Herbert Read, Imagen e idea. La función del arte en el desarrollo de la conciencia bumana, p. 16. 
diestro conocimiento técnico, en ocasiones, también logró producir hermosas obras de arte; debido a que la inspiración de los escribanos, iluminadores y encuadernadores, emanaba de la consagración divina de su obra.

Sirvan pues estas evocaciones como provocación para la reflexión, a propósito de la imagen y su lectura.

\section{BIBLIOGRAFÍA}

Berger, John, Modos de ver, ed. inglesa, 1972. Disponible en: http://paralelotrac.files.wordpress.com/2011/05/modos-dever-john-berger.pdf

Gnoli, Antonio, Entrevista a Umberto Eco. Y asi le puse el nombre de la rosa, 26 de agosto de 2006. Disponible en: http://edant.clarin.com/suplementoscultura/2006/08/26 /u- 01259241.htm [Fecha de consulta: 3 de noviembre del 2013].

Read, Herbert, Imagen e idea. La función del arte en el desarrollo de la conciencia humana, trad. de Horacio Flores Sánchez, México, Fondo de Cultura Económica, 1957. 


\section{Eclipse del libro sacralizado. Avatares del texto y la imagen}

HÉCTOR GUILLERMO AlFARO

Instituto de Investigaciones Bibliotecológicas

$y$ de la Información de la UNAM

scribo textos, no libros", éstas palabras del escritor
Alberto Manguel en su perentoria sencillez señalan
el equívoco de un lugar común y una verdad soslayada: los escritores, los autores, se abocan a escribir textos, enhebrados en discursos, no a hacer libros. Como el propio Manguel agrega: él entrega un texto, en el que se ha esmerado en su escritura, a un editor quien hace o, mejor aún, fabrica el libro. Pero una costumbre ya sedimentada lleva a la gente, e incluso a los autores, al equívoco de decir que escriben libros. Cuando la verdad es que se circunscriben a la labor escrituraria, por muy creativa e innovadora que sea. Lo que por supuesto no demerita su parte en tal fabricación de libros. De hecho, es medular la escritura de los textos, porque sin ellos es difícil concebir un libro, aunque no imposible: no olvidemos que ya se fabrican gran cantidad de libros casi sin palabras o de plano sin ningún texto, constituidos sólo de imágenes; cuestión de suma importancia para ésta argumentación y sobre la que volveremos más adelante. Así, pues, son dos actividades o funciones 
diferentes: el escribir textos y el hacer libros. Aunque como ya se dijo existe una estrecha relación entre ambos, lo que ha redundado en el equívoco de su indiferenciación. Y es en ésta encrucijada donde aparecen las interrogantes a que nos enfrentamos en éste recorrido: ¿cómo es que semejante indiferenciación entre una y otra función (escribir textos y hacer libros) dio lugar a la fetichización del libro y, por ende, a su sacralización? y ¿cúal es la alternativa a futuro para la desacralización del libro?

En las antiguas sociedades signadas por la cultura oral el soporte de la palabra era la voz. Por lo que la información circulaba expansivamente con fluidez y agilidad de boca en boca. Pero era información que se reconstituía una y otra vez a pesar de estar sustentada en una poderosa y sólida memoria colectiva. Más esa reconstitución informativa, al nutrirse del río subterráneo de la imaginación y el mito, ocasionaba poca estabilidad y pérdida de información. El olvido era un mecanismo imprescindible para ajustar la elasticidad de la memoria. Por lo que vehiculizar la ausencia de información sobre el olvido no era catástrofe, sino necesidad para la salud social. Así, con la válvula del olvido se regulaba el exceso de información, la cual, no estaba cercada por un soporte estático que la inmovilizara: información que se mueve y, por ende, reacia a la sacralización. El despliegue civilizatorio, sometido por la complejización de los procesos sociales, económicos y políticos, derivó en la conformación de sociedades sustentadas en estados con gran amplitud de funciones especializadas que producían y requerían mayor información. Pero sobre todo, que esa masa informativa quedara registrada de forma estable y duradera con la intención de utilizarla de manera eficiente y confiable las veces necesarias. Lo que impulsó a gran escala el desarrollo de las escrituras y, con ello, el advenimiento de la cultura escrita. Escritura que se le adecuaron múltiples soportes 
de una variada gama de materiales, recordemos las inscripciones en piedras (un claro ejemplo es la piedra roseta), hasta llegar al punto de inflexión que incide en la escritura y tipo de soporte idóneo, para dar lugar a ese objeto cuasi milagroso que es el libro: empero, este proceso venía acompañado por la sombra del terror al olvido. La consigna subrepticia que rumorea a lo largo de la historia de la cultura escrita es preservar a toda costa la mayor cantidad posible de información registrada. El instrumento que llenaba ese loco afán y exorcizaba al demonio del olvido era el libro; con lo que marcó a fuego el imaginario de la sociedad.

La información, los textos, quedaban indelebles e inalienablemente fijados al soporte, por lo que el libro era así concebido, como unidad con ambas funciones, selladas así por el imaginario: lo que redundaba en el exaltamiento de sus propiedades y hasta fulgurantes atribuciones de cualidades del/al libro; el cual, gracias a ese cúmulo de virtudes, se convertía en la fuente par excellence de la sabiduría, el conocimiento y la información que refleja al universo. De ahí la inflación de metáforas en las que el libro es utilizado para dar razón, justificar o representar cualquier cosa que muestre la grandeza o complejidad de lo creado. Así, por ejemplo, la metáfora más socorrida es aquella que concibe el mundo como un libro donde escribe Dios la creación de todo lo existente. O, esta otra, la ciencia como libro abierto en que se lee (comprende) la naturaleza. La primera metáfora se encuentra directamente relacionada, incluso, podría decirse que deriva de aquellos libros que por sí mismos son considerados como sagrados, caso paradigmático: la Biblia; a la que (mediante un acto de fe) se le atribuye su sacralidad al haber sido escrita precisamente por Dios, quien se erige así como autor que escribe y hace libros, lo cual, torna indiscernible el texto y el soporte. Las religiones que surgieron al cobijo de la cultura escrita apoyaron sus preceptos, 
dogmas y mensajes en una textualidad fijada en libros canónicos, con lo que eran inconfundiblemente sagrados. La palabra escrita acaba siendo reconocida a partir de la materialidad de un libro sacralizado, el cual, por lo mismo, exige pleitesía. De ahí sólo mediaba un paso para otorgarle poderes autónomos y extraordinarios al propio libro: libros que curaban con sólo tocarlos, que podían prever el futuro, que penetraban en las recónditas tinieblas del corazón humano para cambiar, ya sea para bien o para mal, la vida de las personas. Tal es el último giro de tuerca en la vía que conduce a la fetichización del libro, y con ella a su sacralización. El objeto libro transfigurado en fetiche todopoderoso que entre sus páginas aprisiona un texto. Y que pareciera, fuera de esas páginas, que no tiene otras opciones para mostrarse a la mirada.

La imprenta de tipos móviles de Gutemberg va a significar un punto de inflexión en el desenvolvimiento de la cultura escrita, como en la concepción del libro. La amplia producción de libros que genera la imprenta permite que estos ya no sólo sean propiedad de un pequeño sector, sino llegar a la amplia masa de la población, acompañada de la alfabetización universal. Lo que redunda, por un lado, que el libro sea legitimado por la sociedad como contenedor fundamental de textos; pero, por otro, la imprenta también produce masivamente textos con una mayor diversidad de soportes: hojas volantes, carteles, folletos, etc.; que amplían el registro de éstos, así como las posibilidades de los soportes. Mientras en la era moderna se consolida la sacralización del libro, comienza a abrirse una brecha en su aura que atribuye su carácter sagrado. La dinamicidad histórica de la información a lo largo de la modernidad dará lugar a la renovación y creación de nuevos de soportes: como ese último avatar que son los soportes digitales. En los que la textualidad se torna fluida y metamórfica, incluso, surgen opiniones de incertidumbre sobre si deben seguir considerándose 
libros a los textos con soporte electrónico; es tal el prestigio del soporte libro que esto bien puede obedecer a una denominación legitimadora. Pero el medio electrónico se encuentra más acorde con lo que el sociólogo Zygmunt Bauman define como la actual era líquida. Sociedades líquidas, información líquida. Textos que mudan de un soporte a otro, a semejanza de los capitales que emigran de un país a otro, ante la más mínima señal de inquietud.

A lo anterior, agregamos otra brecha que se abre en el corazón de los propios textos: el incontenible ascenso de la imagen; que con la imprenta de tipos móviles tiene también su plataforma de reproducción y difusión. De esta forma, las imágenes adquieren gradualmente un papel protagónico dentro de los libros, e incluso más allá de la frontera de páginas de papel. La publicación de libros en donde las imágenes ganan mayor espacio se incrementa cada vez. Aunque, es de señalar que, en la aurora de la imprenta y durante largo tiempo, fueron comparsas supeditadas a la autoridad de la textualidad del libro. Sin entrar en la descripción de una crónica detallada, podemos seguir su recorrido histórico a través de las páginas de los libros, lo que nos da pauta para comprender su avance: siglos antes de la era Gutemberg los libros contenían imágenes, sin embargo, al ser hechas a mano directamente sobre las hojas resultaban únicas, por igual cada reproducción, lo que necesariamente entrañaba una deformación y, a la larga, redundaba en una gradual estilización de la imagen original. Pero como la prioridad en sus reproducciones era la conservación lo más precisa del texto, las alteraciones que sufrieran las ilustraciones que lo acompañaban no eran de importancia. Acompañamiento que revelaba inequidad: las imágenes solían considerarse más como agregado ornamental para embellecer el libro. Por lo que no entablaban diálogo simétrico y armónico con el texto. Con la imprenta de tipos móviles la relación de texto e 
imagen paulatinamente se va a reconstituir, tanto el uno como la otra pueden ser reproducidos de igual manera inumerables veces. La estabilización y reproducción impresa de las imágenes va a dar pauta para concebirlas y valorizarlas de forma distinta: las ilustraciones, más que agregado ornamental, pasan a ser complemento interactuante con el texto, y a contribuir en la gestación y desarrollo de diversos dispositivos de producción de imágenes, como el grabado y, siglos después, la fotografía, entre otros. Siguiendo esta senda, las ilustraciones van adquiriendo mayor preponderancia, al grado de protagonzar las páginas de una amplia variedad de libros, en los cuales, incluso se encuentran ausentes los textos; a la par, las imágenes impresas salieron de las páginas de los libros transfiguradas en carteles, para colonizar espacios urbanos y poblar conciencias humanas.

Así, las imágenes ponen en cuestión prestigios y privilegios de los textos. Con lo que el fulgor de la palabra escrita, trasfigurada en sinónimo de libro, comienza a sufrir menoscabo. Lo que mina la sacralidad del libro o, en otras palabras, abre la puerta para colocar las cosas en su sitio: un elemento es el texto y otro el soporte con formato de libro. Por un lado, el texto escrito metamorfoseado tecnológicamente en hipertexto ha abierto nuevas formas de construcción y organización del discurso textual, que combina imagen y sonido, mostrando caminos inéditos para la palabra escrita ya no sólo legitimada por el libro. Y éste, por su parte, ahora queda ubicado como un soporte más de textos, aunque su aura sacra pueda aún titilar. No obstante, en el actual contexto líquido de la hipermodernidad, el texto se transfigura en entidad moviente, viajera que puede posarse en múltiples soportes, materialidad le resulta esencial: el soporte (sacralizado o no) es la encarnación que lo ofrece a su lectura. Por lo que el texto no debe ser entendido como arquetipo platónico más allá o por encima de sus múlti- 
ples avatares materiales, perviviendo en sí y por sí mismo incorrupto en un mundo ideal. A su vez, cada tipo diferente de soporte del texto, ofrece una materialidad específica y diferencial que acaba por inficionar los tejidos internos del texto, lo cual, se hace patente al momento de la lectura. Como ha argumentado Roger Chartier, el soporte actúa sobre las formas de lectura de los textos, por lo que de ninguna manera resultan meros envases neutrales de palabras escritas.

Hemos seguido hasta aquí la órbita que va de la fetichización sacralizadora del libro hasta su actual eclipse, con lo que ha quedado en la sombra un factor de carácter subjetivo, pero en cierto modo razón del por qué la persistencia. Un soporte va custodiado por una cauda de afectos en su circulación social: la sacralización del libro genera adherencias afectivas del poseedor de semejante objeto; lo que a su vez, retroactúa como legitimador de dicha atribución de carácter sagrado. De ahí la melancolía a que puede dar lugar la desacralización del libro, máxime si consideramos que tras ésta se agazapa el argumento de la muerte del libro ante el ascenso incontenible y arrollador de los medios electrónicos. Lo que en el fondo encubre una forma invertida de dar carácter sagrado a los medios electrónicos, alimentada por la fascinación infantil que despiertan tales artefactos en la conciencia de las sociedades actuales. Una anécdota que ilustra de manera pavorosamente irónica la muerte del libro y la sacralización del medio electrónico es la que cuenta Sven Birkerts, en su libro de sintomático título: Elegía a Gutenberg, en la que nos refiere cuando en su juventud tenía con un amigo una tienda de libros antiguos y raros, y cómo en cierta ocasión los llamó un profesor de literatura inglesa de una universidad de Detroit porque quería vender su biblioteca. Pero bien vale la pena dejar que el propio Birkerts narre in extenso esta suculenta anécdota, que no tiene desperdicio para la reflexión y la crítica: 


\section{El giro visual en bibliotecología...}

Acudimos: me quedé sorprendido cuando nos abrió la puerta -sólo aparentaba tener uno o dos años más que nosotros-. Dijo: "Quiero venderlo todo". Nos guió a través de un piso amplio hasta su estudio. Al entrar, mi compañero me dio un codazo; la habitación estaba pulcramente forrada de pared a pared con estanterías llenas de libros.

El profesor poseía una colección asombrosa. Reflejaba no sólo las exigencias de su profesión -enseñaba literatura de los siglos XIX y XX- sino también la sensibilidad de un amante de los libros. Los estantes estaban rigurosamente ordenados y los propios libros se hallaban en perfecto estado. Cuando dejó la habitación comenzamos a inspeccionar, contar y tasar los textos. Siempre es un proceso delicado, pues el comprador está a la vez ansioso de no ofender al vendedor y de conseguir los artículos al mejor precio. Adoptamos nuestra estrategia habitual, consistente en realizar una oferta más baja y otra más generosa a que acudir si rechazaba la primera. Sin embargo no hubo necesidad de preocuparse. El profesor aceptó sin rechistar nuestra primera oferta.

Charlábamos mientras metíamos los libros en cajas. Mi compañero le preguntó si se estaba mudando. "No", dijo, "pero me voy". Ambos alzamos la vista. "Quiero decir que me voy del negocio de la enseñanza. Dejo los libros." A continuación comentó que quería enseñarnos algo. En efecto, tras empaquetar y cargar todos los libros, nos guió por el piso y bajamos por unas escaleras. Llegados al sótano encendió la luz. Allí, sobre una mesa alargada, como si se tratara de un objeto en exposición del Museo del Espacio, se encontraba un ordenador y su pantalla. No supe a qué clase correspondía, ni lo sabría actualmente quince años después. Pero el profesor estuvo muy dispuesto a mostrárnoslo todo incluido su funcionamiento.

Mientras él y mi compañero se agrupaban frente a la terminal inspeccioné las estanterías sin mucho entusiasmo. Fue un acto puramente reflejo, pues sólo contenían gruesas carpetas y manuales encuadernados "a mano». "Estoy cambiando mi vida", decía el ex profesor. "Definitivamente, todo lo que ocurra ocurrirá con estos aparatos.» Nos indicó que ya tenía varias ofertas de trabajo interesantes. "¿Y los libros?», pregunté. "¿Por qué los vendía todos?» Tardó un poco en contestar. "Todo lo relacionado con esa profesión me duele mucho", explicó. "No quiero volver a ver ninguno de esos libros en toda mi vida.»

La escena se me quedó grabada. Constituye ya una especie de hito en mi vida mental. Aquella tarde tuve la primera noción seria de que no todo marchaba bien en el mundo de lo impreso y las 
letras. Siguieron toda una suerte de confirmaciones. Nuestro profesor no era un caso aislado, ni mucho menos. A lo largo de un período de dos años conocimos otros como él. Eran mujeres y hombres que habían vislumbrado el futuro y decidido cambiar mientras todavía fuera ventajoso hacerlo. A veces vendían los libros por razones económicas, pero también se daba la necesidad de quemar naves. Era como si afrontar el futuro exigiera la destrucción de los símbolos del pasado. ${ }^{1}$

A semejanza de Birkerts, la escena que nos describe se ha constituido también para mí en un hito, pero por razones matizadamente distintas. Más que interpretarla como el anuncio de un futuro que destruye símbolos del pasado, a la manera del ángel flamígero de la amnesia que incendia los territorios pertenecientes al pasado sembrados por el impreso, la anécdota nos habla de uno de esos espejismos que tantas veces hemos sufrido con las radiantes promesas del futuro; que rara vez se realiza como lo anuncia, suele ser más discreto y realista, incluso, se esmera en contradecirnos. ¿No se dice que el tiempo, esto es, el futuro pone las cosas en su lugar? Los libros no han sucumbido ante el tsunami de la tecnología cibernética, por el contrario, han sobrevivido y gozan de buena salud; es más, conviven y hasta mutan con las nuevas tecnologías. La desacralización del libro impreso y la sacralización del medio tecnológico -nítidamente expresada en la escena de Birkerts- pueden interpretarse de múltiples maneras, una de ellas: la virtud de anunciar subrepticiamente reconfiguraciones pertenecientes a los soportes y a los textos, en las que estos interactúan de múltiples formas: uniéndose, separándose, fragmentándose, fundiéndose... Y esto no sólo como el medio electrónico lo lleva a cabo con los hipertextos, incluso en el soporte de papel sobre el que se pueden posar múltiples textos, que a su vez se re-

1 Sven Birkerts, Elegía a Gutenberg. El futuro de la lectura en la era electrónica, p. 155. 
constituye o entabla creativos rejuegos con las imágenes. Lo que implica comprender al soporte libro como uno más entre otros. Esto no significa quemar las naves, a la manera del apresurado profesor de la anécdota: siempre habrá personas alarmadas que serán las primeras en saltar del barco ante las incipientes amenazas de naufragio. Se trata de colocar el soporte libro en el mismo nivel de importancia, ni más ni menos, que los demás soportes de textos e imágenes. Lo que va a contribuir a la valorización de aquellos "humildes" soportes portadores de textos de "cuestionable calidad" y cuya lectura nunca es considerada, o con reservas, en las grandes encuestas nacionales de lectura. Un ejemplo es el comic, el cual, de cierta manera, tiene la posibilidad de comprenderse también como una alternativa futura ante la desacralización del libro. Opción que, por supuesto, no necesariamente tiene que pasar por la sacralización del medio electrónico.

Es pertinente aclarar que aún y cuando los comics tienen presencia universal en todos los continentes, no poseen en varias latitudes el mismo reconocimiento. Así, gradualmente en Europa y Estados Unidos han alcanzado un estatus de distinción y hasta de privilegio bien ganado de obras de arte $\mathrm{y}$, por tanto, patrimonio cultural; acompañado de su incorporación a los programas de centros de enseñanza básica como superior. Asimismo, materia de estudio, reflexión y práctica por parte de la alta intelectualidad. Por el contrario, en países como México, el comic no goza de buena fama, debido a que es considerado subproducto cultural destinado a clases populares. Por su peculiar combinación de imágenes y textos, los comics son juzgados como dirigidos sólo a personas semianalfabetas o incultas, en el mejor de los casos, propios para aquellos que se inician en la lectura, especie de fase propedéutica, para lo más pronto posible dejarlos a cambio de buenas lecturas encarnadas en los libros. Por lo mismo, resulta difícil concebir a los 
comics como material bibliográfico idóneo para ser incorporado en las bibliotecas. El peso de la imagen en su variante, incluso "menos seria", de caricatura es un agravante para no formar parte del acervo perteneciente a las bibliotecas (aunque en Europa existen propuestas de comitecas): los comics como invitación a una entrega lúdica irresponsable de lectura, contrario a una lectura seria de buena cultura.

En cuanto al soporte de los comics, se le asocia tradicionalmente con el de las revistas, aunque han transitado por todo tipo de soportes de manera fluida, incluso, a través del formato de libro. Por lo que su contenido, constituido mediante el entretejido de imágenes y textos, muestra su independencia respecto a los soportes; más aún, ese entramado se da sobre la base de extrema complejidad en la que se articulan varios lenguajes de forma dinámica. El discurso de los comics, donde dibujos, parlamentos, movimiento, con su respectivos enfoques cinematográficos, se conjuga en una historia delimitada por un marco bien concebido de espacio y tiempo.

La misma evolución del comic ha refinado y perfeccionado estos recursos que componen y definen su propio lenguaje, lo cual, le ha dado estatus de reconocimiento artístico cultural. Y aunque su lectura inmediata parece sencilla, sin mayores exigencias intelectuales, en el fondo entraña una laboriosa complejidad de comprensión por la amplitud de elementos e interacción de estos, que se dan cita en cada historieta. Motivo por lo que no es nada despreciable considerar su lectura, así como la de otros materiales semejantes, no tomados en cuenta en las oblicuas encuestas de lectura de una nación. No es gratuito que entre los jóvenes resulta un material preferido e, incluso, más leído que los libros. Y para sorpresa, nos daríamos cuenta de que en México se lee más de lo que números apoyados en el parámetro libro dictan; lo que evidencia cómo sigue resistiendo la sacralización del libro. 
Así, el comic nos abre una ventana al futuro y con ello decirnos que el horizonte es más amplio de cómo lo consideramos desde la perspectiva del libro o el medio electrónico sacralizados. No olvidemos que los eclipses son pasajeros, una vez que pasan, el sol brilla más que antes.

\section{BIBLIOGRAFÍA}

Alfaro López, Héctor Guillermo, Introducción a la lectura de la imagen, México, UNAM-DGB, 2008.

Aumont, Jacques, La imagen, Barcelona, Paidós, 1992.

Baron-Carvais, Annie, La historieta, México, FCE, 1985.

Birkerts, Sven, Elegía a Gutenberg. El futuro de la lectura en la era electrónica, Madrid, Alianza Editorial, 1999.

Calabrese, Omar, El lenguaje del arte, Barcelona, Paidós, 1987.

Casanueva, Mario, Bolaños, Bernardo (Coord.), El giro pictórico. Epistemología de la imagen, Barcelona, AnthroposMéxico, UAM, 2009.

Chartier, Roger, ¿Qué es un texto?, Madrid, Ediciones Círculo de Bellas Artes, 2006.

Hazan, Eric, Shiffrin, André, et al., ¿Para qué sirve el libro? Divagaciones heterodoxas, Madrid, Editorial Popular, 2009.

Díaz, Carlos, Apología del libro, Madrid, Fundación Emmanuel Mounier, 2012.

Didi-Huberman, Georges, Arde la imagen, México, Ediciones Ve, 2012.

Gauthier, Guy, Veinte lecciones sobre la imagen y el sentido, Madrid, Cátedra, 2008. 
Gubern, Roman, El lenguaje de los comics, Barcelona, Península, 1979.

Literatura de la imagen, Barcelona, Biblioteca Salvat, 1973.

Lucía Megías, José Manuel, Elogio del texto digital. Claves para interpretar el nuevo paradigma, Madrid, Forcola, 2012.

Lyons, Martin, Libros. Dos mil años de historia ilustrada, Madrid, Lunwerg, 2011.

Manguel, Alberto, El sueño del Rey Rojo. Lecturas y relecturas sobre las palabras y el mundo, Madrid, Alianza Editorial, 2012.

Mirzoeff, Nicholas, Una introducción a la cultura visual, Barcelona, Paidós, 2003. 


\title{
Los modos de leer y ver, a propósito del libro y las imágenes
}

\author{
MiNERVA ANGUIANO GONZÁlEZ \\ Universidad Iberoamericana
}

\section{INTRODUCCIÓN}

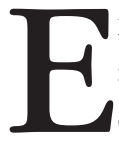

n la década de los años sesenta, el reconocido crítico de arte John Berger, presentó en la BBC de Londres una serie que tituló Modos de Ver. La serie de cuatro episodios trataba sobre cómo se había construido la mirada de occidente en torno a diversos tópicos de la vida cotidiana, el impacto del programa fue mucho más amplio de lo que el autor o la BBC se esperaban. Entonces, se planteó la idea de "hacer" un libro, convertir imagen (documental) en otra imagen (documento). Este nuevo despliegue de imagen, en principio, tenía que evidenciar la constante tensión de la intersección entre información, imagen y conocimiento, la cual, se reconoce en diversos momentos de la historia, al tiempo, tenía que poner de relieve cómo la imagen ha disputado, desde siempre, un lugar en el contingente campo del conocimiento, o invención de éste, como precisaría Nietzsche.

¿Qué lugar se les ha signado y significado a las imágenes? ¿Por qué sigue siendo un tema complejo para diversas discipli- 
nas el compendiarlas como parte de sus documentos y no como meras ilustraciones?. Son algunas de las interrogantes que problematizo en este ensayo. Para ello, citaré autores y polémicas vinculadas con el leer y ver, que dicho sea de paso, son acciones idénticas, no obstante que a través del cristal de la academia, parecieran separarse tangencialmente. Razón por la que presentó esto como una invitación a repensar en cómo dividimos, categorizamos y configuramos el mundo a partir de supuestos.

\section{LOS MODOS DE LEER Y VER O MANERAS DE FORMAR IMÁGENES}

Jacob Burckhardt (1818-1897) y Johan Huizinga (1872-1945) calificaban las imágenes como testimonios "a través de los cuales podemos leer las estructuras de pensamiento y representación de una determinada época". ${ }^{1}$ Esta noción, sin duda, permea un amplio espectro de los estudios sobre imágenes, una suerte de romantización de ellas solo por ser imagen, algo así como "el arte por el arte", pero debemos tener cuidado y no seducirnos por estas metáforas, la imagen es, en principio, potencia que se traduce en afectos. Aunado a ello, es inmanente, se derrama, se desdobla, se encripta, se cataloga, se prohíbe, se "recupera", etc.: "la imagen es una visión que ha sido recreada y reproducida. Es apariencia, o conjunto de apariencias, que ha sido separada del lugar e instante en que apareció por vez primera". ${ }^{2}$ Y esto se complica más cuando nos referimos a la imagen en el libro y se piensa a éste como contenedor de imágenes y no como una imagen en sí.

1 Peter Burke, Visto y no visto: el uso de la imagen como documento bistórico, p. 13.

2 John Berger, Modos de ver, pp. 15-16. 
Berger nos da pautas o salidas a este laberinto epistemológico, ya que, intuyendo probablemente los derrames de la imagen, propuso en su libro una suerte de intersección entre objeto, imagen y conocimiento, es decir, el libro como estos tres conceptos, por medio del cual, podemos penetrar en el "mundo de las imágenes" desde lugares que no hemos visto, ya que, como él sostiene, "solamente vemos aquello que miramos. Y mirar es un acto voluntario, [...] Nunca miramos sólo una cosa; siempre miramos la relación entre las cosas y nosotros mismos". 3 Por lo tanto, y haciendo eco a lo anterior, partiremos de la noción: la imagen es un simulacro y una ilusio al momento en que la vemos.

Trataré de aclarar el panorama, y para ello, he tomado como eje de análisis algunos textos de medicina, en los cuales ha prevalecido la discusión en torno a la imagen y su posibilidad o potencialidad de representación. Presento dos textos, el primero data de 1543 y el segundo de 1906, en ambos se discute la noción de imagen como evidencia, no como ilustración, y ello nos sirve en el marco de este seminario.

\section{LA IMAGEN Y LA "EVIDENCIA"}

La imagen documento y documental, así como sus intrincadas historias, deslizan ante los estudiosos de estas su sentido polisémico. Se tiene registro del sentido didáctico y teológico para el cual fueron utilizadas hasta finales del siglo XVIII: se sabe que en iglesias y monasterios de la Edad Media, además de las cortes principescas, hasta fines dicho siglo, la recepción colectiva de las imágenes no se daba de manera simultánea,

3 Idem. 
sino mediada por etapas y jerarquías. ${ }^{4}$ A partir de dichos registros, se ha sentado como supuesto de verdad que el sentido o fin de las imágenes era en su mayoría el de enseñar, mostrar y aleccionar con base en condicionamientos teológicos. Sin embargo, cuando echamos ojo a los libros, cuyo sentido no era necesariamente religioso, es decir, de "ciencia", nos enfrentamos a otras preguntas. Si bien es cierto las imágenes se consumían y consumen a nivel jerárquico, también aparecían con diferentes intereses, ojos o modos de ver.

Para explicar lo anterior, me sirvo de la portada del libro De Humani Corporis Fabrica de Andrea Vesalio (véase figura 1). Esta cumple con diversos propósitos, el primero: la presentación, mismo que se puede reconocer en la cartela de la parte superior central; y segundo, mostrar y "evidenciar" los contenidos que ahí se estudiaban. De esta forma, se presenta una imagen en la cual podemos reconocer un auditorio repleto de médicos y curiosos, observando atentos la autopsia que se está practicando al cuerpo de una mujer. La imagen y su presentación significaron en su momento un problema teológico, debido a que el cuerpo se concebía como improfanable por la mano del hombre, y cuando se hacía se consideraba acto desviado, hereje. Vesalio se enfrentó a estas problemáticas, más aún, porque su libro era probablemente el primero que se ilustraba. Si bien es cierto, libros de medicina existieron, y muchos de ellos con ilustraciones, también lo es que la mayoría de estas estampas fueron agregadas en ediciones posteriores, de ahí que el atrevimiento de Vesalio se veía con recelo entre sus contemporáneos.

La estrategia que propuso fue presentar la "evidencia" de lo que "aparecía” en las autopsias y cirugías, es decir, un pintor

4 Walter Benjamin, La obra de arte en la época de su reproductibilidad técnica, p. 38. 
Los modos de leer y ver...

Figura 1

Portada de De Humani Corporis Fabrica, Andrea Vesalio, 2001




se daría a la tarea de retratarlo de la manera más real posible, "las ilustraciones debían ser un sucedáneo del cadáver hendido, desollado, trozado, compareciendo sobre los grabados como yacía bajo el escalpelo", 5 para ello, mandó comisionar las imágenes al taller de Tiziano. Asimismo, y probablemente sin intensión de ello, Vesalio propuso y presentó otro modo de ver, ya que hizo del lector un espectador y desplegó el sentido iconográfico de la imagen como un componente tan significativo, en el plano del conocimiento, como el texto.

Ahora bien, queda aún sin resolver cómo justificar el cuerpo desollado, mutilado, y con los órganos expuestos en estampas de esa época, sin duda, encontramos la respuesta en el imagen misma. En la lámina Septima Mvsculorvm tabula (véase figura 2) se presenta el cadáver desollado y sin órganos de un personaje sin género, ni rostro; el cuerpo está situado en primer plano y dispuesto en un paisaje árido, desierto probablemente, éste pende de una soga que lleva en el cuello, dicha soga exime automáticamente al espectador de ser observador morboso o hereje, ese era un cuerpo corrupto y destinado a eso, a la objetivación y pauperización.

Vale recordar que varios artistas ya habían trabajado con cadáveres directamente, como el caso de Leonardo Da Vinci (1452-1519), quien en su quehacer artístico y de investigación científica disecó "más de 30 cadáveres entre 1487 y 1515 y produjo miles de esquicios y cientos de notas cuya influencia fue, no obstante, virtualmente nula", 6 su trabajo no se dio a conocer sino hasta el siglo XIX, y precisamente en una edición especial, en la cual, se destaca la imagen sobre el texto. Leonardo expuso en sus notas "Este plan que he hecho del cuerpo humano te

5 Rafael Mandressi, La mirada del anatomista: disecciones e invención del cuerpo en Occidente, p. 107.

6 R. Mandressi, La mirada del anatomista..., op. cit., p. 114. 


\section{Figura 2}

Lámina Septima Mvsculorvm tabula, De Humani Corporis Fabrica, Andrea Vesalio, 2001

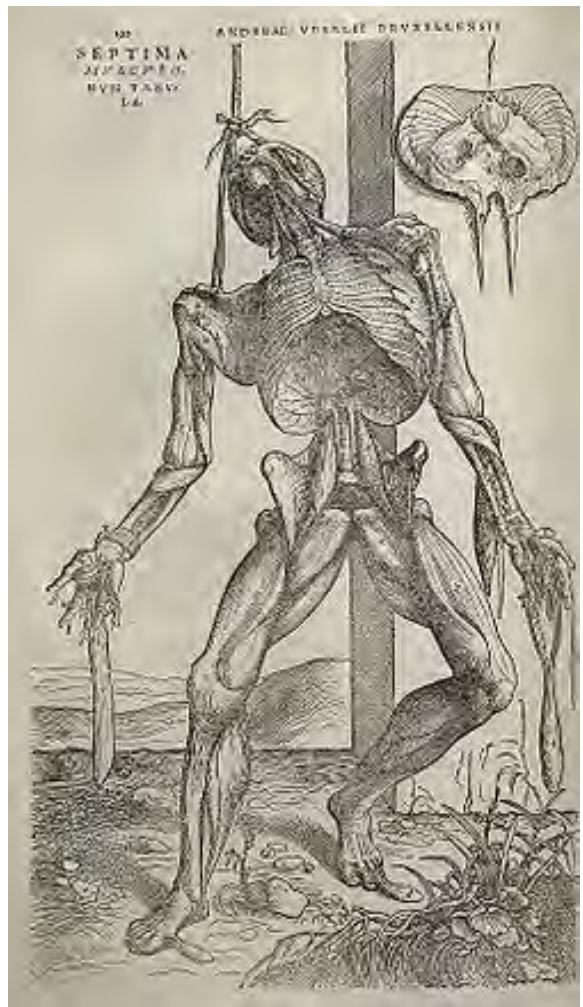

será expuesto como si tuvieras delante de ti al hombre verdadero"7 Y subrayó la especificidad del conocimiento visual “Con qué palabras, oh escritor, podrás igualar la perfección de todo el orden cuyo dibujo se encuentra aquí?". 8 Así, de cierta forma, vaticinó el sentido de la imagen como evidencia, o como

$7 \quad$ R. Mandressi, op. cit., p. 115.

8 Idem. 
lo dijera Kurt Tucholsky (1890-1935): una imagen dice más que mil palabras.

El sentido del espectador-lector se continuó en los libros de medicina y este salió del ámbito de las bibliotecas y de la ciencia para ingresar al mundo de la vida cotidiana y lo familiar, tal y como lo constatamos en el libro La mujer médico del hogar. Obra de higiene y de medicina general, especialmente consagrada a las enfermedades de la mujer y los niños al tratamiento de los partos y a los cuidados de la infancia.?

Poco podemos rastrear de la autora, pero su libro nos da mucho para el estudio de las imágenes. La obra, tal como lo indica su título, estaba dedicado a las mujeres que atendían labores de parto en casa; el médico sólo era solicitado en casos de cesáreas o complicaciones mayores en aquellos años, por lo que las mujeres atendían gran parte de los partos. La instrucción médica, previa atención a pacientes, no estaba dada en la aulas, se les daba por medio de imágenes y experiencias narradas, por ello es que nuevamente la imagen aparece como evidencia, testimonio que permite conocer el mundo de lo desconocido del conocimiento, tal como sostuvo Berger "las imágenes se hicieron [...] para evocar la apariencia de algo ausente", ${ }^{10}$ en este caso, la irrepresentable enfermedad.

El libro de Fischer, al igual que el de Vesalio y de Berger, propone la intersección entre información, conocimiento e imagen, cuenta con 450 grabados y trece láminas, por lo que el papel protagónico de la imagen es incuestionable. Las láminas eran acompañadas de una explicación escrita, tal como lo observamos en la lámina dos Perfecciones y deformidades del

9 Ana Fischer-Dückelmann, La mujer, médico del hogar: Obra de higiene y de medicina familiar, especialmente consagrada a las enfermedades de la mujer y los niños, al tratamiento de los partos y á los cuidados de la infancia. 
cuerpo femenino (véase figura 3). En la imagen contemplamos la disposición del cuerpo de la mujer como si fuesen esculturas, sin embargo, no se presentan con la intención dignificante de la musa, sino como objetos de estudio. A partir de dichas figuras se reconocen en principio las perfecciones -las de la Venus de Medici- y deformidades, las de la demacración caquéctica y la obesidad patológica. Asímismo, ofrecen el remedio a la enfermedad, el cinturón de Juno, mismo que "solo molesta algunos días" pero permite alcanzar la perfección. De esta forma, comprobamos el cómo la imagen deviene en condición de verdad, y me refiero a la imagen de la Venus, misma que se construyó como figura ideal, pero que en el momento de reproducirla en el hombre, o en este caso la mujer, resulta completamente arbitraria y fantasiosa, como se observa en la lámina que ilustra el busto y la caja torácica de la Venus, en contraste con la de una cortesana francesa (véase figura 4).

Es en este mismo libro, la fotografía aparece como eje narrativo fundamental, y como imagen incuestionable, por no pasar a través del "proceso humano creativo". Veamos la lámina 13 Caras de mujer enferma (véase figura 5). En ella se presentan rostros de cuatro mujeres, cada uno enmarcado por un ornamento oval y debajo letras que indican "nerviosa", "anémica", "enfermiza", "escrupulosa". Son los rostros de mujeres que padecen diferentes males, y me permito transcirbir lo que se escribe sobre ellas:

Muchas de nuestras lectoras sentirán pena al examinar los rostros enfermizos representados en esta lámina, dos de los cuales no dejan de ofrecer atractivo por su belleza. ¡Son tantas las hermosas enfermas! En los leves cambios de la fisionomía se refleja como en un espejo el estado de salud general. La de la mujer nerviosa es de una movilidad extraordinaria. La primera de las figuras representa un tipo de esta clase, de ojos expresivos é inquietos. La segunda corresponde al de la mujer anémica cuyo semblante contrasta notablemente con el de la nerviosa. La postración de todo su ser se revela 
Figura 3

Lámina 2 Perfecciones y deformidades del cuerpo femenino. Ana Fischer, 1906






\section{Figura 4}

Busto y caja torácica de la Venus de Milo y de una cortesana francesa. Ana Fischer, 1906

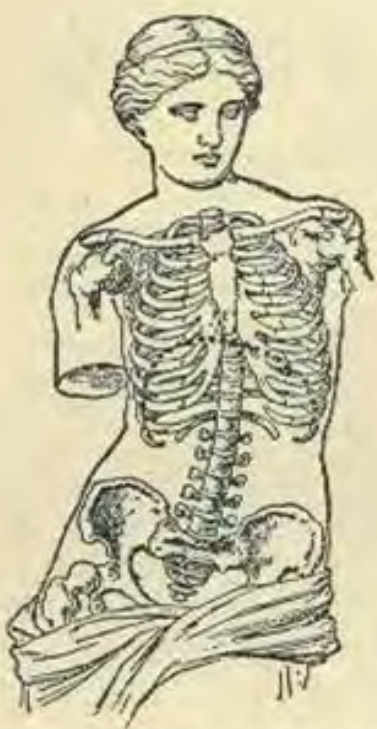

Yig. 3. Bu. Buto y caja taráciea de la Vernes de Milo



Pige, ifh. Busto 5 naja torácinu dy uas eortesana francesat.

en lo lánguido de la mirada. Ninguna de estas dos mujeres goza de salud, á pesar de su bella apariencia y de la redondez de sus mejillas. La tercera figura representa a una anémica, de débil sistema nervioso, acaso tuberculosa. La cuarta es la de rostro menos bello: los ojos y la nariz parecen inflamados, y los labios abultados denotan poca salud: es esta una mujer linfática. Invitamos á las madres á que hagan en este sentido un examen atento de la fisionomía de sus hijas para que puedan leer en sus rasgos el estado de su salud. ${ }^{11}$

11 Ana Fischer-Dückelmann, La mujer, médico del hogar..., op. cit., lám. 13, sin pág. 
El conocimiento y la imagen entonces no se deben leer disociadamente, no se puede uno escapar del otro, es una relación dialéctica en constante devenir. Y si la imagen es captada por un actante, es decir, un actor no humano -en este caso la cámara fotográfica-, entonces esa imagen es conocimiento, evidencia y documento.

Un último ejemplo, y no es precisamente de medicina, pero si vinculado con el carácter higienista de los dos anteriores, se trata del Registro de mujeres públicas ${ }^{12}$ de la ciudad de México, mismo que se llevó a cabo desde mediados del siglo XIX. Dicho registro se realizó a solicitud del propio Maximiliano, quien sugirió que una forma de contener las múltiples enfermedades sería registrando con fotografía y datos a las mujeres que se debía vigilar.

Las entonces mujeres públicas tuvieron que presentarse ante la junta de sanidad para ser registradas, les solicitaron llevarán un fotografía para ilustrar su registro; de los documentos que actualmente se conservan de ese primer registro, podemos reconocer cómo se explicita y evidencia la representación, como simulacros e ilusio, ya que cada mujer pública se presentó de modo diferente, las hay quienes optaban por aparecer con atributos artísticos, es decir, con guitarra, o a modo de danza, y había quienes se mostraban como mujeres de la aristocracia. Las formas fueron múltiples y variadas, esto cambió ya entrado el siglo XX, cuando se les retrataba de modo frontal y sin permitir algún atributo. Por lo tanto, la construcción del documento e imagen es parecido al movimiento pendular, en ocasiones lo sentimos más próximo, más documento y en otras, más lejano, como una suerte de ilustración que se ubica en otro momento.

12 Primer Registro de Mujeres Publicas conforme al Reglamento expedido por S.M. el 17 de febrero de 1865. 


\section{Figura 5}

Caras de mujer enferma

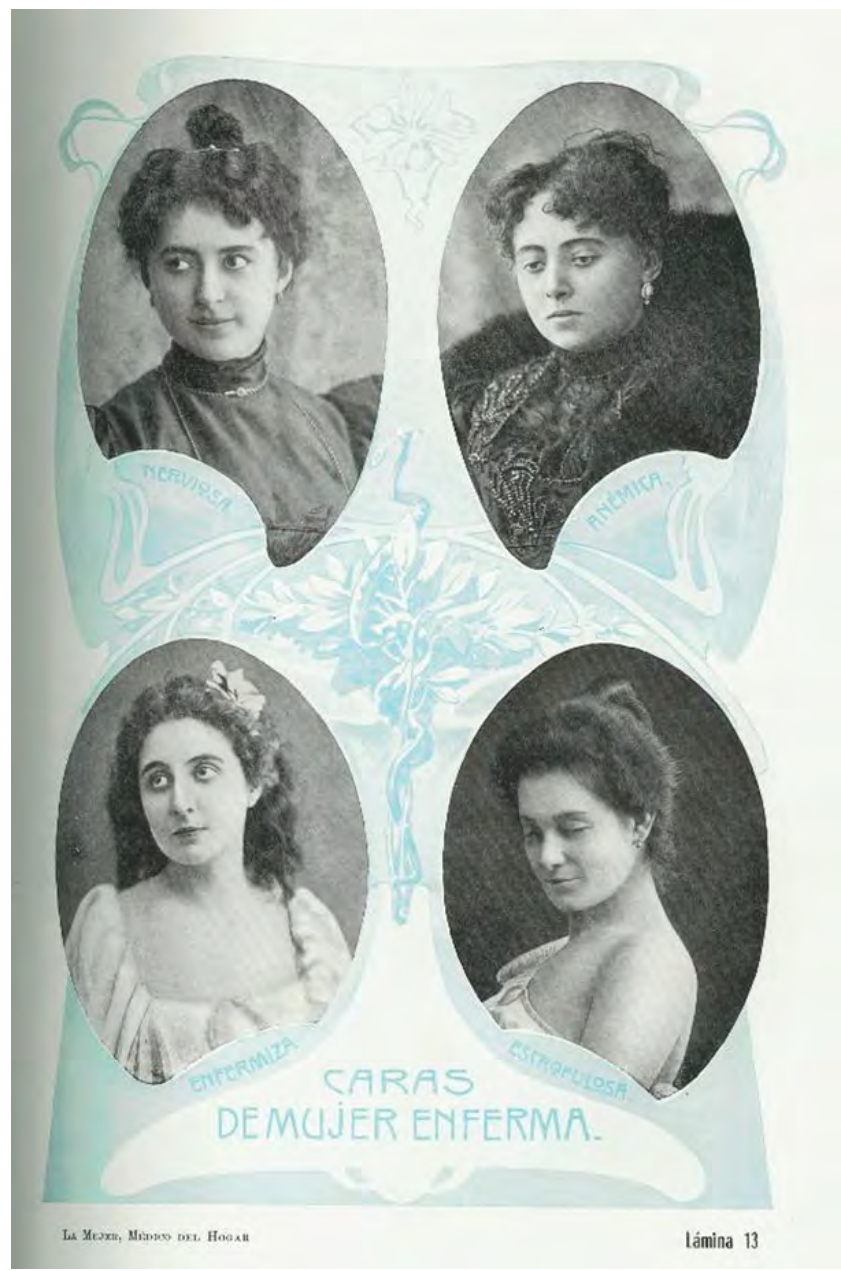

Es aquí donde se da ésta intersección, la que tanto preocupa a los especialistas en libros y su clasificación, los libros en ocasiones estuvieron más próximos, más normalizados, en otras, más lejanos, destinados a espacios privados. Sin embargo, esto 
significa cómo la imagen se desliza y desplaza en los libros, en la vida cotidiana; es una imagen del mundo contenida en un tiempo pasado siempre ajeno, al igual que el texto, al igual que el libro.

\section{A MODO DE REFLEXIÓN FINAL}

Resultaría pretencioso dar conclusiones de un tema que apenas esbozo, sin embargo, nos quedan varias ideas en el tintero, en principio, la noción de romper estructuras de catalogación y organización, rupturas que permitan revisitar problemáticas nuevas en torno al sujeto frente a su quehacer investigativo en las bibliotecas; y la segunda, la imperante necesidad de generar nuevas herramientas o metodologías para acercarse a los libros, a las imágenes contenidas en ellos, y a las formas de pensar sobre esas imágenes dentro de los libros, evitando supuestos y tratarlas como objetos artísticos. Las imágenes son evidencia, al igual que los libros, y como tal, debemos tratar de acercarnos a ellas cuestionando, indagando y dejando que se derramen. 


\section{BIBLIOGRAFÍA}

Benjamin, W. La obra de arte en la época de su reproductibilidad técnica, México, Itaca, 2011.

Berger, J. Modos de ver, Barcelona, Gustavo Gili, 2000.

Burke, P. Visto y no visto: el uso de la imagen como documento bistórico, Barcelona, Crítica, 2001.

Fischer-Dückelmann, A. La mujer, médico del hogar: Obra de bigiene y de medicina familiar, especialmente consagrada a las enfermedades de la mujer y los niños, al tratamiento de los partos y á los cuidados de la infancia, Barcelona, Maucci, 1906.

Mandressi, R. La mirada del anatomista: disecciones e invención del cuerpo en Occidente, México, Universidad Iberoamericana, 2012.

Primer Registro de Mujeres Publicas conforme al Reglamento expedido por S.M. el 17 de febrero de 1865, Ciudad de México, Inspección de Sanidad.

Vesalio, A. \& Pigeaud, J. De humani corporis fabrica, Turin, Italie, N. Aragno Editore, 2001. (Publicado originalmente en 1543). 


\title{
Las peripecias de la imagen: los memes, la digitalización y las portadas
}

\author{
JONATHAN HERNÁNDEZ PÉREZ \\ Coordinación de Humanidades de la UNAM
}

lo largo del tiempo, el lenguaje escrito, el verbal y las imá-
genes, han tenido importancia fundamental en el desa-
rrollo de las sociedades humanas, el uso de éstos elementos para representar conocimiento nos ha acompañado desde tiempos remotos y están presentes en prácticamente cualquier cultura del mundo.

En este sentido, si queremos comprender el avance y papel que actualmente representa la imagen, resulta obligado realizar un recorrido histórico-social por las diferentes sociedades que han hecho uso de ella. Por ejemplo, la revolución científica del siglo XVII es un caso de cómo el conocimiento científico y matemático se desarrolló en buena medida gracias a los saberes acumulados en arte y pintura. ${ }^{1}$

Conviene detenernos en este punto, para recordar la etimología de la palabra imagen, pues en un considerable número de

1 Mario Casanueva y Bernardo Bolaños, (coords.) El Giro pictórico: epistemología de la imagen. 
idiomas occidentales, como francés, italiano, inglés, portugués, o español, se observa la procedencia del latín imago: figura, sombra, imitación; del griego eikon: icono, retrato, mientras que en alemán para referirnos a ella se utiliza el vocablo bild, cuyo significado remite a construcción o formación. ${ }^{2}$

Esto es importante mencionarlo ya que la idea que aún impera en muchos campos disciplinares y en la sociedad en general es la de imagen como copia, resultado de un proceso imitativo o de reproducción lo más exacto posible, de la cual no se puede obtener ni producir nuevo conocimiento. Esta percepción de imagen puede estar influida por el propio origen de su palabra, debido a que hasta la fecha parecería que todavía se nos dificulta analizarla, estudiarla, investigarla, como algo más que un simple objeto de contemplación, es decir, verla como resultado de una construcción en el que intervienen procesos de percepción, cognición, registro e interpretación.

Sin embargo, la exclusión de la imagen, en términos epistemológicos, no es privativo etimológicamente de esta palabra, hay que considerar factores que han detenido el reconocimiento de la imagen como objeto de conocimiento. Pensemos en su desarrollo a la par de la escritura plasmada en un soporte; el libro.

El recorrido que han tenido las imágenes a través del tiempo, tiene una estrecha relación con el desarrollo del libro impreso durante sus primeros años de vida, pues durante mucho tiempo la producción de ambos objetos era limitada y únicamente accesible a determinada población. Sin embargo, la masificación del libro logró superar a la imagen en cuanto a producción, autoridad social y objeto de conocimiento, dejando a la imagen como mero objeto de placer y contemplación. A esto habrá que sumarle la poca importancia por la imagen durante

2 Lourdes Roca, "La imagen como fuente: una construcción de la investigación social”, en Razón y Palabra. 
los estudios básicos, pues durante la trayectoria escolar se le otorga un carácter secundario muy alejado de poderla interpretar o analizar; por lo tanto, su lectura no tiene presencia en las aulas.

La imagen, además de ser una forma perteneciente a la expresión de las emociones, también es manifestación de la actividad intelectual, en cierta forma, puede ser explícita en temas que el texto, la letra, pasan por alto fácilmente. También es valioso testimonio y reflejo de múltiples aspectos de las prácticas sociales, que no siempre documentan otros soportes; puede incluso constituir un testimonio de aquello que muchas veces no dicen las palabras. ${ }^{3}$

En este sentido, con el surgimiento de medios como la televisión, el cine y la fotografía, la imagen comenzó a consolidarse en diferentes aspectos, pues estos no sólo han constituido un reflejo de la sociedad que les dio vida, sino que han fungido como agentes activos en la creación de valores y estereotipos aceptados socialmente ${ }^{4}$ (o rechazados por la sociedad). Asimismo, han servido de plataforma para el incremento en la producción de imágenes que tenemos hoy día.

Incluso, habrá que sumarle el incesante avance tecnológico que se ha desarrollado durante las últimas décadas, particularmente en materia de información, pues los mecanismos de transferencia, multiplicación y producción lograron que ésta llegara a más lugares con mayor rapidez.

3 Lo que dio origen a la famosa cita "una imagen vale más que mil palabras", la cual, ha sido cuestionada por diversos autores, pues en cierta medida para decodificarlas es necesario verbalizar sobre ellas.

4 Isis Saavedra Luna, "La historia de la imagen o una imagen para la historia". en Cuicuilco. 


\section{TIPOLOGÍA DE LAS IMÁGENES}

Con el fin de entender el contexto de las imágenes, es necesario establecer una tipología que nos permita enfocarnos a un determinado tipo de imagen. Para términos prácticos, conviene rescatar la que establece González de Ávila:5

Las imágenes perceptivas (o naturales); resultado de la percepción que transporta a la conciencia un estado de cosas del mundo, la imagen perceptiva se refiere a un proceso en el que se concatenan naturaleza y cultura, percepción y cognición, objeto y significado. Estas se determinan bajo un esquema complejo, pues la percepción es caracterizada por ser un proceso constructivo de adaptación al ambiente, además de un comportamiento cultural colectivo.

Las imágenes mentales; producto de la actividad cognitiva perteneciente a la formación de representaciones o simulacros en ausencia de todo hecho perceptivo, son particularmente aquellas que producimos durante nuestras ensoñaciones y objeto de estudio de las neurociencias.

Las imágenes técnicas (o artificiales); resultado de la fijación sobre un soporte cualquiera (papel, lienzo, pantalla, etc.), las cuales, se convierten además en fuente de alimentación social, tanto para la captación de imágenes perceptivas como de la formación de imágenes mentales.

Resulta una manera sencilla de tipificar las imágenes, ya que esta categorización es, como lo menciona el propio autor, insa-

5 Manuel González de Ávila, Cultura y razón: antropología de la literatura y de la imagen. 
tisfactoria, debido a que es difícil privilegiar una sobre otra, incluso, enfatizar que la imagen técnica no es menos perceptiva que la así denominada, pues vemos por igual una fotografía que un objeto del mundo natural, y cualquier imagen perceptiva o técnica lo es también mental, dado que se procesa en las redes neuronales y no sólo en los órganos de los sentidos.

De esta manera, los tres tipos de imágenes que mencionamos, se encasillan en el terreno de las técnicas, las cuales, permean nuestro imaginario colectivo y repercuten en la creación de imágenes mentales y en la percepción de la naturaleza y la cultura.

Es necesario enfatizar que las tecnologías, la Internet por ejemplo, han hecho algo más que dar a ver una imagen: han cambiado quizá la naturaleza misma de la visión. Enfatizo la Internet por que esta tiene lugar especial en el auge, multiplicación y valoración de imágenes. Si bien la Internet comenzó con un estilo que le daba mayor peso al texto y poco se ocupaba de imágenes, actualmente se ha convertido en un medio que ha potencializado la producción y distribución de éstas en todo el mundo; desde fotografías personales, ilustraciones acompañadas de textos, memes, etc.; diariamente se producen y comparten millones de imágenes a través de la red.

En este sentido, mucho se ha argumentado sobre los sustitutos visuales, por efecto del abuso icónico que resulta de la multiplicación de imágenes, llegando incluso a suplantar la realidad, o por lo menos disfrazarla. Por ejemplo, el libro de viajes o documental suplantarían el destierro; la videoconferencia a la interacción física, la pornografía al sexo, las galerías virtuales a la imposibilidad de visitarlas en otras latitudes, el diseño asistido por computadora, que permite modelos geométricos, logra innumerables representaciones de objetos complejos (edificios, aviones, automóviles). Todo esto se ha maximizado con el desarrollo de la tecnología. 


\section{Figura 1}

Captura de imagen de un recorrido virtual por el Museo de Antropología en México a través del Google Art Project



Fuente: Google Art Project.

\section{MEMES}

El término meme fue acuñado por el científico Richard Dawkins, un pro-evolucionista, que en su libro The Selfish Gene (1976) buscaba un paralelo a la evolución darwiniana e introdujo la teoría de la memética de transmisión cultural, la cual, sugiere que las ideas se comportan, en la conciencia colectiva de la gente, de manera similar a los genes en el acervo genético. ${ }^{6}$ De esta manera, Dawkins nombra como meme a la unidad mínima de información que se puede transmitir; quiere decir que los memes conformarían la base mental de nuestra cultura, como los genes configuran la primera base de nuestra vida, de tal manera que una idea o un meme se forma en la mente de un individuo a partir de otras ideas pre-existentes y, si tiene éxito,

6 Amanda Lavelle, "Internet Memes: Technological Culture and Communication". 
pasa a otras mentes a través del habla, la escritura, la demostración y actualmente a través de la Internet.

El imaginario social está íntimamente ligado a imágenes icónicas que refuerzan y pueden convertir en legítimas las visiones políticas y sociales, los memes tienen un lugar particular en la cosmovisión del usuario de la Internet, que incluso se traslada al mundo físico. El término meme en Internet se utiliza básicamente para describir una idea, concepto, situación, expresión y/o pensamiento manifestado en cualquier tipo de medio virtual y de construcción multimedia y colectiva que se populariza a través de la red, mediante sitios web, blogs, foros, chats, y particularmente en redes sociales. De acuerdo con Knobel y Lankshear (2007), los memes de la Internet funcionan como "patrones contagiosos de información cultural" es decir, a modo de un meme análogo superficial, los cuales, pasan entre los usuarios para dar forma a las acciones y mentalidades pertenecientes a determinado grupo social. Así, las creencias religiosas, movimientos de arte, objetos de moda, títulos o letras específicas de canciones, situaciones políticas, profesiones, estados de ánimo, etc., son representados a través de los memes.

Este tipo de imágenes pareciera no tener significado para alguien que rara vez utiliza la Internet o que nunca la ha utilizado, sin embargo, la importancia de los memes radica en su no compleja elaboración, ya que son realizadas, en su mayoría, por usuarios para usuarios, de cierta forma es una manera de democratizar la imagen, ya que al momento de crearse y compartirse, comienza a viralizarse ${ }^{7}$ a través de los usuarios en cuestión de minutos, rompiendo barreras de idioma y lugar, reelaborando el significado de esa imagen, incluso adaptándola a la cultura en la que se inserta.

7 Entiéndase "viralizar" como la capacidad de cualquier contenido en Internet (audio, video, imagen, etc.) para reproducirse en forma exponencial, como un "virus". 
Figura 2

Restauración del Ecce Homo, que se convirtió en uno de los memes más compartidos durante el 2012, con múltiples reelaboraciones



Fuente: Rocío Huerta, El Pais. La restauración de un eccehomo se convierte en un sainete mundial.

Sin embargo, los memes prácticamente no tienen larga vida, normalmente son reemplazados por nuevos memes de moda, además, probablemente gran parte de ellos no serán recordados, pero los que sí, habrán tenido algún tipo de repercusión entre los usuarios de la Internet, e incluso algunos rompen la barrera de lo virtual para apreciarlos en carteles, espectaculares, portadas, vídeos, etc., es decir, en un medio distinto a la Internet.

A pesar de que los memes son considerados simples imágenes graciosas (en la mayoría de los casos) también representan una forma de comunicación entre usuarios de la red (aunque no siempre con éxito). En este sentido, conviene mencionar; los que se producen en tiempos de inestabilidad social y política, las imágenes insertas en ellos, han llegado a ser icónicas, un ejemplo, la estilizada máscara que se utiliza en la película $V$ de ven- 
ganza, inspirada en el conspirador católico inglés Guy Fawkes, es usada comúnmente para generar memes en torno a la disidencia política, convirtiéndola en imagen de carácter universal.

Los memes son una manera distinta de resaltar mensajes que con el solo uso del texto no tendrían el mismo alcance. Además, nos pueden decir e indicar aspectos importantes de la cultura tecnológica en la Internet.

\section{LA DigitAlizACIÓN}

En la actualidad disponemos de un enorme depósito de imágenes ya producidas, difundidas y recibidas. Las cuales, están sujetas a constante proceso de reelaboración, repetición y variación, ya sea por el auge de la red o previamente por el desarrollo del cine y la fotografía, éstas imágenes están compuestas por otras temáticamente vinculadas entre sí. A ello habrá que agregarle la característica de alteridad, favorecida por la digitalización de la imagen.

Durante los últimos años, la digitalización de material documental, particularmente en bibliotecas y archivos de todo el mundo, ha sido un importante hito para su distribución, en términos de acceso a material documental poco conocido. Así, la conversión a versiones digitales de mapas, diagramas, ilustraciones, carteles, etc., ha invadido bibliotecas y otras unidades de información, posicionándose como un atractivo servicio al poner a disposición de millones de usuarios en todo el mundo, un importante número de imágenes a las que difícilmente podrían tener acceso por estar resguardadas en bibliotecas de diferentes latitudes.

Si tomamos en cuenta que la digitalización es una reproducción fiel, tenemos que considerar que el documento resultante reúne tres características indispensables: calidad, en el enten- 
dido de ésta como funcionalidad y valor de uso; permanencia, en el concepto de que el documento sea accesible por un lapso considerable; e interoperabilidad, significa que el documento será asequible en varias plataformas y programas de computadora. ${ }^{8}$ Además, hay que agregarle el tratamiento a la imagen digitalizada, el cual, deriva un problema en términos de interpretación y de su propia lectura, el cual, no se abordará aquí.

En este sentido, muchas imágenes digitalizadas suelen ser reelaboradas por los propios usuarios, creando nuevas a partir de las ya existentes y diseminándolas a lo largo de la red, incluso, los procesos fallidos de digitalización han sido objeto de manifestaciones artísticas en línea?

\section{LAS PORTADAS}

El libro en su forma estética ha tenido distintos cambios a lo largo del tiempo, la portada es uno de los elementos que más lo evidencia, las partes que lo conforman en la actualidad se fueron configurando con los años, mientras que otras desaparecieron o trasladaron a otros sitios del libro.

Actualmente las portadas ${ }^{10}$ de los libros suelen cambiar en cada nueva edición, resulta interesante comparar las primeras ediciones de libros ahora consagrados, con las portadas que actualmente nos ofrecen las distintas editoriales que los producen, libros como Farenheit 451 de Ray Bradbury, El lobo estepario de Hermann Hesse, portadas que han vuelto a editarse en sus ediciones orignales como El gran Gatsby de F. Scott

\footnotetext{
8 Juan Voutssas Márquez, Bibliotecas y publicaciones digitales, p. 64.

9 Martin Bryant, "Google Books scanning errors turned into works of art".

10 Si bien en la jerga profesional se utilizan otros términos como cubierta, tapa, forro, carátula, funda, camisa, entre otros. Para el desarrollo de este trabajo se utilizarán de manera indistinta los términos portada y cubierta.
} 
Fitzgerald por su adaptación cinematográfica, incluso, la célebre novela de Vladimir Nabokov Lolita, ha tenido numerosas representaciones visuales en distintos países.

\section{Figura 3}

Lolita de Vladimir Nabokov, edición de 1987 por la editorial Rowohlt, Reinbek

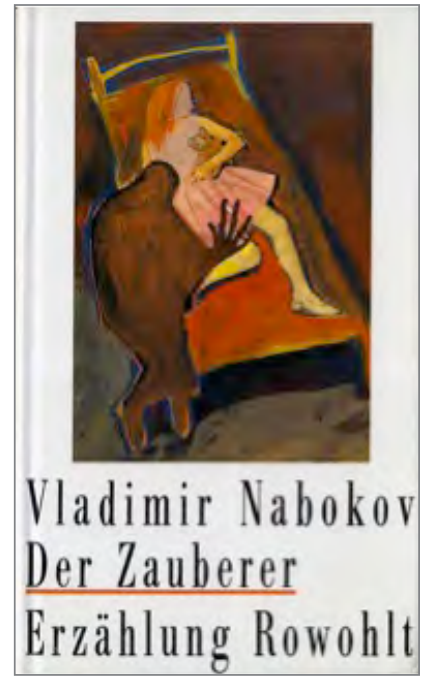

Fuente: Covering Lolita.

De esta manera, algunas portadas se insertan en el imaginario colectivo, pues al momento de mencionar el título de la obra, se nos viene a la mente la imagen exterior del libro, la ilustración, los colores, la fotografía, la tipografía o la famosa pintura que se utilizó para ilustrarlo, invitándonos no solo a la contemplación sino a la lectura de esa imagen.

Ejemplo de cómo la lectura de imagen y de texto se concatenan en un solo elemento, ya que tanto la primera como el segundo nos permean desde los primeros años de vida, sin embargo, la imagen es el primer gran acercamiento con nuestros sentidos, 
la cual, en el mejor de los casos, nos va a acompañar durante toda la vida. En este sentido, Saavedra Luna ${ }^{11}$ indica que desde la infancia hay una lectura e interpretación de las imágenes que vemos; primero, desde la familia, de donde se infiere un medio social y cultural determinado; y más tarde, por medio de la educación formal, en la que, si bien intervienen decisiones individuales, también existen tendencias oficiales determinadas por el Estado y el poder económico. De ahí que una misma imagen motiva diferentes lecturas y valoraciones, más allá del contexto original en que fue creada.

\section{CONCLUSIONES}

La cantidad, diversidad e importancia que presentan las imágenes en la actualidad no hace sino manifestar la necesidad de fomentar la reflexión e investigación en torno a éstas, para posicionarlas como objeto de conocimiento en diversas disciplinas. Sin embargo, no basta con estudiarlas e investigarlas, es necesario también producir material visual como parte del discurso de las imágenes en tanto vehículos conceptuales.

Particularmente, en la disciplina bibliotecológica se tendría que abordar a la imagen tanto en sus factores formales, como de contenido y contexto, evitando el riesgo de exclusión y fomentando la producción y el estudio de éstas como una forma más de generar conocimiento, así como valorar la necesidad de una formación visual, tanto en los planes de estudio como en la práctica profesional, evitando así la ceguera cognitiva ante la abrumadora presencia de las imágenes.

11 I. Saavedra, op. cit., p. 4. 


\section{BIBLIOGRAFÍA}

Bericat Alastuey, Eduardo. Imagen y conocimiento: la incorporación de la fotografía a la investigación social. http:// www.fes-web.org/uploads/files/modules/congress/10grupostrabajo/ponencias/719.pdf (Consultado el: 28 -10-2013).

Bryant, Martin, "Google Books scanning errors turned into works of art". The Next Web. http://thenextweb.com/google/2012/03/18/google-books-scanning-errors-turned-into-works-of-art/ (Consultado el: 20-10-2013).

Casanueva, Mario y Bernardo Bolaños, (coords.), El Giro pictórico: epistemología de la imagen, México, UAM-Unidad Cuajimalpa, 2009.

Covering, Lolita, http://www.dezimmer.net/Covering\%20Lolita/slides/1987\%20BRD\%20\%27Der\%20Zauberer\%27\%20 Rowohlt,\%20Reinbek.html (Consultado el: 4-10-2013).

Ferradini, Sonia, Tedesco, René. "Lectura de la imagen", en Comunicar, núm. 8 (1999). http://www.redalyc.org/articulo. oa?id=15800821 (Consultado el: 21-10-2013)

González de Ávila, Manuel, Cultura y razón: antropología de la literatura y de la imagen, México, UAM-Iztapalapa, División de Ciencias Sociales y Humanidades, 2010.

Google Art Project, "Museo de Antropología de México". Google. http://www.google.com/culturalinstitute/asset-viewer/ museo-nacional-de-antropolog\%C3\%ADam\%C3\%A9xico/C wEMAX5agejbLg?location=19.426218032836914\%2C-99. $187576293945312 \% 2 C 1.9700000286102295 \% 2 C v E 0 A A N m$ rdjzJR19WXs9Z2w\&hl=es\&projectId=art-project (Consultado el: 21-10-2013). 
Hristova, Stefka, "Visual Memes as Neutralizers of Political Dissent", en TripleC Communication, Capitalism \& Critique, núm. 1, 2014. http://www.triple-c.at/index.php/tripleC/ article/view/507/541 (Consultado el: 1-08-2014).

Huerta, Rocío, "La restauración de un eccehomo se convierte en un sainete mundial" en El País, Agosto, 23, 2012, Sección de Cultura, en: http://cultura.elpais.com/cultura/2012/08/ 23/actualidad/1345709139_149007.html [Fecha de consulta: 21 de octubre de 2013].

Knibbs, Kate, "Are Memes The Pop Culture Art of Our Era?": http://www.digitaltrends.com/social-media/when-does-ameme-become-art/ (Consultado el: 21-10-2013).

Knobel, Michele, and Colin Lankshear, (eds.) A New Literacies Sampler, New York, Peter Lang Publishing, 2007. http:// everydayliteracies.net/files/NewLiteraciesSampler_2007. pdf (Consultado el: 1-07-2014).

Lavelle, Amanda, "Internet Memes: Technological Culture and Communication", en http://people.umass.edu/alavelle/capstone.pdf (Consultado el: 21-10-2013).

Roca, Lourdes, "La imagen como fuente: una construcción de la investigación social”, en Razón y Palabra, núm. 37, 2004. http://www.razonypalabra.org.mx/anteriores/n37/1roca. html\#1 (Consultado el: 25-10-2013).

Saavedra Luna, Isis, "La historia de la imagen o una imagen para la historia", en Cuicuilco, núm. 10, 2003. http://www.redalyc. org/articulo.oa?id=35102912 (Consultado el: 1-10-2013).

Voutssas Márquez, Juan, Bibliotecas y publicaciones digitales, México, UNAM, Centro Universitario de Investigaciones Bibliotecológicas, 2006. 
INTERVENCIONES VISUALES SOBRE EL CONCEPTO LIBRO Y BIBLIOTECA 


\title{
Presentación
}

\author{
JENNIFER VOUTSSÁS LARA \\ Posgrado en Bibliotecología y Estudios \\ de la Información de la UNAM
}

L

a información como objeto es un ente que se manifiesta no solamente en diversos soportes, sino en formas inimaginables, por ello, considero que nuestra disciplina aún tiene un amplio espectro de investigación por descubrir y estudiar. Para esto, es necesario conocer enfoques multidisciplinarios que permitan complementar nuestros estudios sobre la información. Los Bibliotecólogos y profesionales de otras disciplinas afines, estamos en busca de saber esas nuevas formas en que la información se manifiesta para describir, conservar y difundir. Una de ellas es la imagen como objeto de estudio.

La imagen es tema de discusión entre colegas de nuestra disciplina, el cual, por ser objeto de difícil aprehensión, requiere ser analizado desde diferentes métodos y complementado con aportes de otras ciencias. Las imágenes son importantes porque dan cuenta del imaginario social que las produce y éste, a su vez, denota el espacio social que se asigna a la lectura. Los siguientes textos no pretenden indicar ni significar un método para leer las imágenes, sino mostrar las posibilidades 
de lectura de la misma así como los lazos que guarda con la lectura de la palabra.

Las lectoras a través del espejo: el discurso de la lectura en imágenes, es un discurso reflexivo que nos lleva de la mano para leer y comprender imágenes de lectoras y la mirada que les devuelve el espejo. Dejo al final de esta presentación una reflexión de cómo la imagen y la palabra escrita pueden complementarse en un estudio disciplinario para entender el mundo en que vivimos.

En El mapa cuenta una imagen, tenemos la visión de una historiadora cuya pasión por los mapas la llevó a percatarse de la inexistencia de uno de ellos, se trata del mapa utilizado en la película El automóvil gris (1919). Circunstancia que la llevó a reflexionar sobre qué otras fuentes documentales pueden usarse para seguir las huellas de la historia. Así, a partir de un objeto que los Bibliotecólogos normalizamos para su conservación: el mapa, nos muestra cómo un objeto de información puede convertirse en imagen, y cómo la imagen puede ser rica fuente de estudio. La autora nos invita a leer el mapa tal imagen para recrear y comprender escenarios de la ciudad de México en 1915.

Finalmente, agradecemos la participación del curador Iván Granados Hay, en esta mesa que versó sobre La colección de libros de artista como parte de una biblioteca especializada en arte contemporáneo, y que no forma parte de esta compilación.

Cada propuesta es una atenta invitación al lector para que, al adentrarse en los textos, se tome el tiempo necesario para observar con mayor detalle las imágenes, con el objetivo de enriquecer su conocimiento no solamente basado en la palabra escrita, sino también en las imágenes, lo cual, le permitirá comprender el discurso de estos autores y su contexto. 


\title{
Las lectoras a través del espejo: el discurso de la lectura en imágenes
}

\author{
GRACIELA LETICIA RAYA AlONSO
}

Facultad de Filosofía y Letras de la UNAM

Abora, Mino, si prestas atención y no bablas tanto, voy a contarte todo lo que yo pienso de la Casa del Espejo. En primer lugar está el cuarto que ves en el espejo y que es exactamente igual que nuestro salón, salvo que las cosas están a la inversa... Pero tal vez no sea otra cosa que apariencia... Luego, fíjate, los libros son parecidos a los nuestros, sólo que tienen las palabras escritas al revés.

Lewis Carroll




del espejo, esta imaginativa y curiosa lectora-personaje, en el momento de cruzar al otro lado del espejo, iba a mostrarnos el camino para dirigirnos hacia el interior de la imagen, a vernos desde el otro lado del espejo.

Se dice que los espejos fueron inventados para que uno pudiera conocerse, pero, ¿qué son los espejos?: una alegoría de la visión exacta, del pensamiento y del trabajo de la mente, en ellos podemos ver, metafóricamente hablando, la representación imaginada de una cosa siempre influenciada por el modelo, es decir, por la idea que le dio origen. ${ }^{1}$ Como bien sabemos, cuando miramos en el espejo lo que está a la izquierda aparece a la derecha. Es el llamado principio de inversión que Platón consideraba producto del encuentro entre el fuego interior con el exterior, que se manifestaba justo cuando nuestra visión se enfocaba en espejos o superficies brillantes y pulidas. Visión que cuando se le oponía otro espejo nos devolvía no una, sino múltiples imágenes, llevando a postular que esa era la forma en que los espejos reflejaban entre sí las imágenes; mise en abîme del reflejo.

Esta forma de percibir las imágenes en el espejo, llevó a creer que en ellos no sólo se representaban o reflejaban objetos e individuos, sino que parecía dotarlos de vida propia; las imágenes podían hablarnos, devolvernos la mirada. De ahí que hayan sido fetichizadas, convertidas en espejos mágicos y, por ende, temidas. Esta vitalidad que parecía reflejaban los espejos, la encontramos más viva en las imágenes que, como sociedad, producimos, lo cual, es producto del efecto de interpelación presente en la imagen misma: "la imagen nos saluda, nos llama, o se dirige a nosotros, mete al espectador en el juego, envuelve al observador como objeto para la 'mirada' de la imagen", por ello, las imágenes requieren ser explicadas, leídas. Con

1 Jurgis Baltrušaitis, El espejo, pp. 9 y 86.

2 William T. J. Mitchell, Teoría de la imagen, p. 72. 
ellas sucede algo similar a cuando miramos a través de un espejo, sólo vemos lo que queremos o lo que podemos ver; porque, al igual que en el espejo, se desdoblan, duplican e invierten.

Estas características de la imagen se comprenden mejor cuando somos capaces de reconocer los fantasmas con los que cohabitamos cotidianamente, los cuales, no son otra cosa que nuestras percepciones primarias, nuestros sueños e ilusiones. Somos habitantes de dos mundos: uno, llamado real, extrínseco, tangible; el otro, intrínseco, imaginario, pero no por ello menos real y tangible que el primero. Mundos que reproducimos de diferentes maneras, por ejemplo, a través de imágenes y lectura, tanto de la palabra como de la imagen.

Michel Foucault dice que cohabitamos ambos mundos, el de nuestra realidad material que percibimos a través de los sentidos y el que se complementa con nuestro mundo interno. Este último lo visualiza como una utopía, en él ponemos nuestros ideales y esperanzas acerca del mundo que quisiéramos vivir, el cual, no se encuentra en ningún lugar físico, tangible, y, sin embargo, está allí. En contraparte de este mundo, habla de las heterotopías, el espacio construido socialmente: el de los mitos y ritos, el de valores y tradiciones. La metáfora del espejo nos sirve entonces para introducirnos en ambos mundos, porque el espejo suspende, neutraliza e invierte la "realidad", crea un mundo virtual tras la superficie donde todo tiene existencia real, el espejo nos devuelve la mirada, permite vernos donde no estamos. ${ }^{3}$

3 Foucault enuncia sus conceptos textualmente así: utopía, como los lugares sin especio real: "espacio vacío de espacio"; y heterotopía, como "contraespacio..., espacios reales... delineados por la sociedad... que pueden hallarse en el seno de una cultura a un tiempo representados, impugnados o invertidos... espacios que están fuera de todos los espacios aunque, no obstante, sea posible su localización". El espejo, en tanto real, es una heterotopía: "El otro lado del cristal" desde el cual "me devuelvo hacia mi persona y vuelvo mis ojos sobre mí mismo y tomo cuerpo allí donde no estoy". Michel Foucault, Los espacios otros, p. 3. 
¿Qué podemos ver a través del espejo de las imágenes de las lectoras? Aunque el reflejo es múltiple, en el discurso con relación a la lectura femenina, se expresan dos vertientes que comparte la interpretación en general. La primera se relaciona con su utilidad formativa, necesaria y pertinente para toda persona; la segunda, es una forma de desviación en el camino, pues lleva a la ociosidad, al placer, misma que se convierte doblemente perniciosa para la mujer, dada su conceptualización histórica como sexo débil, física e intelectualmente hablando.

Las imágenes, por medio de la exteriorización y teatralización, representan la concepción perteneciente a la lectura y a las lectoras, entre otras cosas, reflejan cómo la lectura en silencio le permitió a la mujer generar un espacio propio: íntimo e interior. El primero, en tanto el propio desarrollo sociocultural, hizo necesario que la mujer coadyuvara a su educación y a la de los hijos por medio de la lectura, lo cual, le permitió escaparse un poco de la mirada vigilante de la familia, la iglesia y demás instituciones sociales. Esta lectura debía realizarse en el lugar que por antonomasia se considera propio de la mujer, el ámbito doméstico y, por supuesto, durante sus ratos libres. Además, sus lecturas debían abocarse a temas religiosos, de higiene y cuidado de los hijos.

El segundo espacio de lectura, y más importante, es el interior, es decir, un mundo donde, por medio de la lectura, las mujeres viven otras vidas y construyen un mundo propio. En el que, al identificarse con las emociones de otros, potencializaban su capacidad para sentir, aunque también se creía que las exponía a perderse entre ficción y realidad. No sólo eso, esta interioridad, al plasmarse en imagen, alude a otros atributos de la mujer, como poderes espirituales, mágicos y místicos que la iconología tradicional y moderna ha representado de diferentes formas. Acerquémonos al espejo, veamos una conocida imagen que expresa parte del imaginario social en torno a la 
lectura y, en particular, a la femenina: La lectora de novelas, de Antoine Wiertz (véase figura 1).

\section{Figura 1}

La lectora de novelas, Antoine Wiertz ${ }^{4}$



Se trata de una imagen que denota estos dos espacios, el de la intimidad de la alcoba y el de la interioridad psíquica. En ella, el cuerpo de la protagonista y el espejo son las claves para iniciar nuestra lectura: la desnudez y voluptuosidad corporal de la lectora, el gesto de su rostro, la inclinación de su

4 Antoine Wiertz, "La lectora de novelas", en Heroínas, Catálogo de la exposición. 
cuerpo, la forma en que su mano sostiene la almohada, nos dan la pauta para saber que está experimentando el placer de la lectura. El espejo nos devuelve su reflejo y, al hacerlo, nos hace conscientes de que al espiar a la joven lectora nos hemos convertido en una especie de voyeristas, ${ }^{5}$ gozamos a partir de mirar la imagen, nuestro fuego lector se ha topado con el fuego externo de la imagen de la opulenta lectora, y por ello podemos entender su gozo.

\section{Figura 2}

Detalle de La lectora de novelas

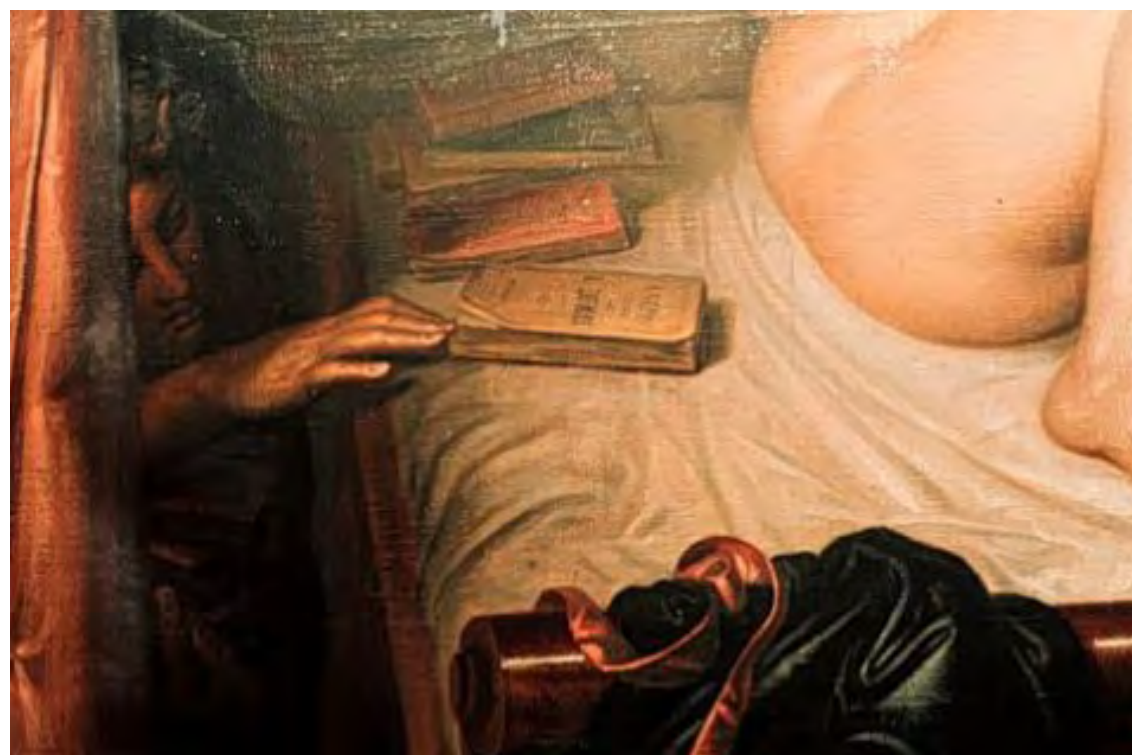

Pero, en ella existen otros elementos (véase figura 2), los libros, entre ellos, uno de Alexandre Dumas, que si bien ya sabíamos que nuestra joven era lectora de novelas, un género que

5 Retomo parte de la interpretación de Guillermo Solana, en Heroínas, Ibid., p. 45. 
no era aceptado por relacionarse con ocio y placer, este detalle materializa los fantasmas que habitan en esta imagen. El diablo, escondido en la esquina de la cabecera de la cama, y quien le suministra los libros, reafirma la falta en que la lectora está incurriendo, y nosotros con ella, al experimentar su gozo. En este caso, el espejo no es la puerta de entrada a la imagen, es un espectador, como nosotros, del mundo que habita la imagen.

Para cruzar al otro lado, es necesario tener presente que los mundos que proyectan las imágenes de las lectoras tienen una función concreta, cultural e histórica, por ejemplo, La lectora de novelas nos advierte de los peligros que encierran ciertas lecturas, es una advertencia moralizante inherente a la época en que fue pintada. Pero hay otras amenazas: la lectura estimula la imaginación, permite la conquista de espacios de libertad propios, hacernos independientes e, incluso, generar nuestra personal visión de mundo, riesgos latentes para cualquier época.

Una vez reconocida su función, debemos encontrar la llave de entrada, es decir, los mecanismos de apertura y cierre del espacio contenido en la imagen. Se asemeja a un rito de paso, el cual, nos accede a múltiples espacios que contiene, e incluso pueden yuxtaponerse dentro de ella, como sucede en la imagen audiovisual. El lenguaje de las imágenes logra decodificarse a través de la iconología, de manera conjunta con otros métodos de lectura, como la semiótica. No obstante, la imagen, al igual que su lectura, tiene algo de indomable, salvaje, por lo que al acercarnos a ella bien valdría tener presente la semejanza con Narciso, estamos ante una imagen fugitiva que refleja nuestra propia imagen. ${ }^{6}$

6 “Por qué te obstinas vanamente en atrapar una imagen fugitiva?. Lo que buscas no existe, el objeto que amas date la vuelta y desaparecerá. El fantasma que percibes no es más que el reflejo de tu imagen, sin consistencia por sí mismo, ha venido y permanece contigo; contigo se alejará si puedes alejarte...”, J. Baltrušaitis, op. cit., p. 241. 
Figura 3

Mujer leyendo frente al espejo ${ }^{7}$

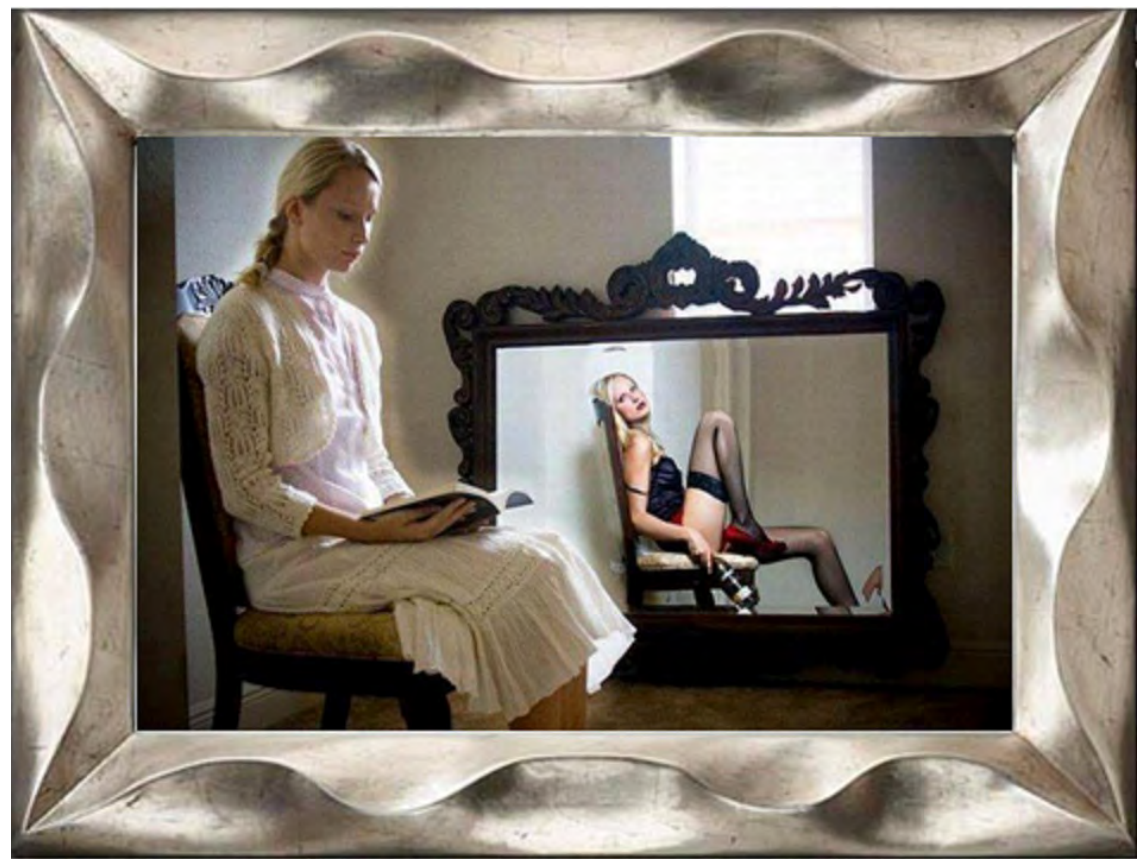

Por ejemplo, la imagen Mujer leyendo frente al espejo (véase figura 3), muestra a una virginal lectora, su pureza se denota en lo blanco de su vestido, en el leve fulgor que emana de su cuerpo, que nos recuerda al aura relacionada con las imágenes celestiales. Su vestido holgado de cuello alto oculta cualquier rasgo que evidencie su sexualidad; el suéter, cubriéndole los brazos y su cabello atado con una cinta blanca, reafirman esta impresión. Su postura recta pero relajada denota que se encuentra concentrada en la lectura. La llave para entrar a esta imagen está en el rostro y manos de la lectora. Su mirada la

$7 \quad$ [Mujer leyendo frente al espejo] en línea. 
proyecta en el libro que se encuentra sobre su regazo, con la mano extendida, pero los dedos firmes, sosteniéndolo; mientras con la otra, ausente en la imagen, mantiene el libro abierto, la puerta también está abierta.

En este caso, el libro es el primer espejo, la lectora ha cruzado hacia el espacio de la lectura, la imagen denota su capacidad de inversión pues el libro, que suele relacionarse con superación de la vida mundana por contemplación virtuosa, ha conducido a la lectora por los caminos del placer de la lectura. El espejo proyecta el fuego interior de la lectora, en él, ella reaparece en actitud sensual, su atuendo se corresponde con nuestras fantasías, se complementan: medias negras, camiseta de encaje negro con la cinta colgando sobre el brazo, con los tacones rojos que hacen juego con su braga. Allí, el libro se ha transformado en una botella de vino.

En el espejo se exterioriza el mundo interior que la lectora ha construido a través de la lectura en la intimidad de la alcoba: dimensión fuera del espacio y el tiempo, realidad dentro de la realidad. La sobriedad del cuarto, con sus paredes pintadas de blanco y libre de objetos, revela la censura social inherente al tipo de lectura que está realizando, y de la cual ella ha escapado. La mirada de la chica del espejo expresa la complicidad, la imagen se cierra sobre sí misma y nosotros lo percibimos a través del juego de miradas reflejadas en el espejo libro y en el espejo imagen.

Cabe hacer notar que la blancura y el vacío de las paredes que rodean a la lectora, pueden ser rápidamente poblados por los fantasmas que el espectador inconscientemente proyecta, la mirada de quien observa con atención manifiesta su propia concepción de la lectura. 
Figura 4

El espejo de la lectora ${ }^{8}$

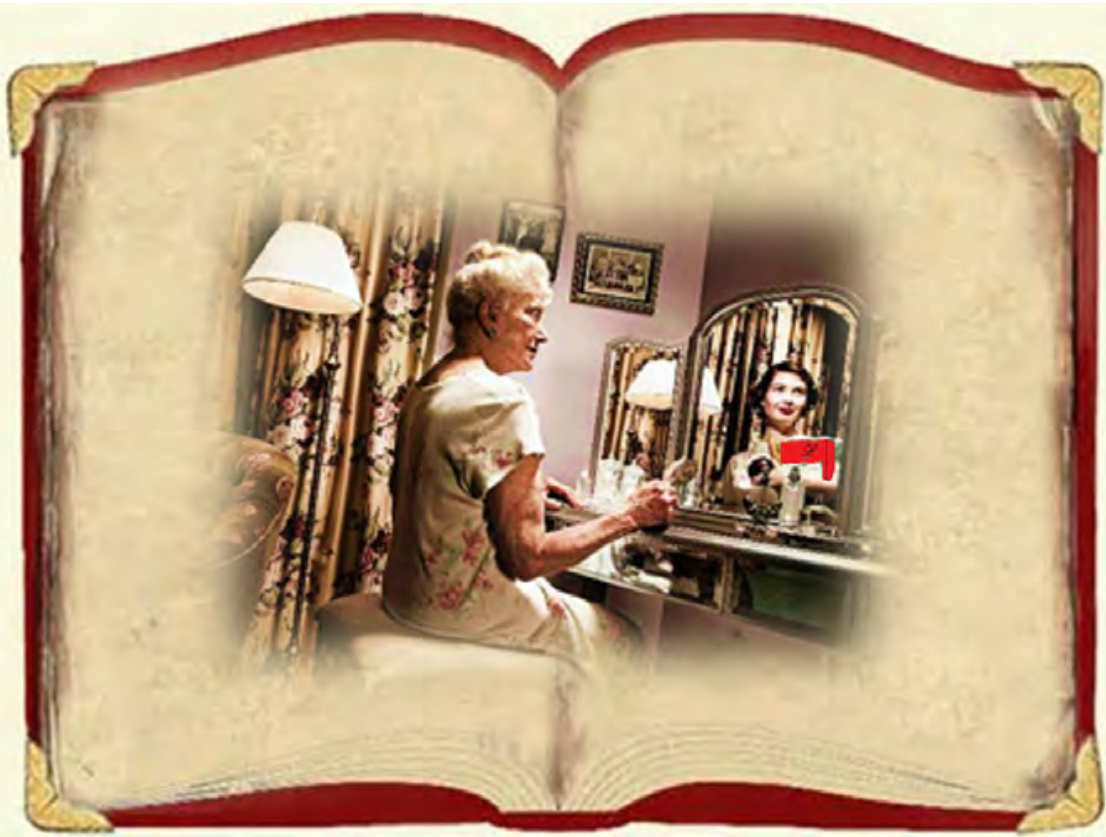

La imagen de esta concentrada lectora nos ha permitido acercarnos, pero no todavía entrar en la imagen, porque para ello se requiere de un rito de paso. Mismo que podemos vislumbrar en la imagen El espejo de la lectora (véase figura 4).

Nuevamente nos encontramos en un espacio íntimo, el libro funge como espejo, donde a través de una historia nos podemos encontrar con nosotras mismas en diferentes etapas de nuestras vidas. Las cortinas corridas y la lámpara encendida indi-

8 Esta imagen, a la que he dado el nombre de El espejo de la lectora, forma parte de una serie de fotos que reflexionan sobre la edad. Tom Hussey, Reflections. 
can que ha llegado la noche temporal y cronológicamente de la protagonista central: la lectora que se mira en el espejo perteneciente a la lectura.

Su cabello plateado y sujeto en la parte superior de su cabeza hace juego con la madurez de su piel. Su mano reposa sobre el tocador mientras sostiene firmemente el cepillo, acción que marca el instante en que ella, como Alicia, ha penetrado al otro lado del espejo. El mundo interior que se le revela es otro, pero el suyo mismo. Aquí, el libro es el espejo que nos permite entrar.

Es una imagen reflexiva, donde los tres espejos del tocador se comunican imágenes. La dama mira hacia el espejo lateral y para nosotros refleja la habitación, pero en él, el mundo exterior e interior se encuentran unidos a través de la mirada de la mujer madura. Esta es la representación que le comunica al espejo central y que es el que nosotros podemos ver. Allí nos encontramos con una joven y bella lectora, lo sabemos porque abraza un libro junto a su pecho, su sonrisa revela las expectativas y esperanzas de su edad, pero también su satisfacción. Su mirada en el espejo la vuelve hacia sí misma, el espejo es la puerta de entrada al mundo interior construido a partir de la lectura. El libro, que desde fuera nos remite a la materialidad, dentro recupera su simbolismo como recipiente de la gracia divina, vehículo de la espiritualidad, su reflejo está personificado en una lectora madura que se encuentra en el espacio intemporal de la lectura.

Por otra parte, en el cortometraje titulado Books and reading, ${ }^{9}$ nos encontramos ante la historia de una vida a través de la lectura. Aquí, una niña se está iniciando en la lectura y a través de ella tendrá una visión de futuro. El mundo exterior que la rodea le es adverso, las paredes se encuentran agrietadas, descarapeladas, al igual que el techo. El piso de madera se

9 Ver cortometraje: [Books and reading]. 
ve sucio, descuidado, incluso algo podrido. Ella, sentada sobre el suelo contra la pared, hojea un libro. Sus ojos son el primer espejo, al posar su mirada en el libro y comenzar a leer, las palabras, cual si fuera un hechizo, despliegan las alas de la imaginación simbolizadas por la jaula que cuelga del techo y que libera a los libros cual si fueran aves. ${ }^{10}$

La ventana es el segundo espejo, el rayo de luz que se filtra a través de ella y las nubes que la envuelven simbolizan la creación del mundo interior que comienza a construirse en ella y que la envuelven en una especie de estado de gracia. El mundo exterior sigue presente, aunque ahora las ventanas de madera que se encontraban cerradas y que lucían desvencijadas se han abierto, han cobrado un mejor aspecto y sobre todo dejan pasar algunos rayos de sol, ese mundo aún es hostil, pero algo de alguna forma comienza a diluirse. El libro la guía en esta aventura, la conduce hacia el siguiente espejo donde su futuro mundo interior le será revelado. ${ }^{11}$

Desde el espejo, una bella joven sale a su encuentro. Y, es la mirada desde el espejo la que esta vez observa a la pequeña lectora. La niña no deja de leer su libro hasta que frente al espejo, las miradas se encuentran. El fuego interior de la pequeña lectora se ha encendido y esto es lo que la hace crecer, le descubre lo que puede ser si permite que la lectura la cobije y guíe su camino. Las ramas de la enredadera que sube alrededor del espejo e invitan a cruzar al otro lado, son como las hojas de un libro que la incitan a seguir adelante. Desde ese otro lado, nota cómo las hojas continúan reproduciéndose, cubriéndola, mientras que las paredes del mundo exterior que lleva consigo comienzan a cambiar. Es recubierto con un papel tapiz que, aunque en algunas partes roto, le proporciona cierta calidez

10 Idem, ver del segundo 00:00 al segundo 00:18

11 Ibid., ver del segundo 00:19 al segundo 00:30 
de flores doradas, expresa la transición psíquica que se está llevando dentro de ella. ${ }^{12}$

Del otro lado, es el libro quien la guía, y cual si fuera un acto de magia, convierte una alfombra en espejo de agua sobre el que ella se sumerge. La lectora ha ingresado a una lectura profunda que le permitirá transitar de la juventud a la mediana edad. Sin embargo, aquí algo ha cambiado, el mundo exterior que la rodea se muestra por primera vez seguro, firme, límpido, pareciera que, como Alicia al entrar en la cueva del conejo blanco, hubiese entrado en un mundo de revés, donde el techo es el piso. Su cabello cae mientras ella se encuentra sentada en un sofá leyendo, en tanto a su alrededor gran cantidad de libros mueven sus hojas rítmicamente. ${ }^{13}$ Es el momento en que el mundo interior de la lectora le ha permitido construir un espacio interior propio, donde se siente segura de sí misma, dudas y prejuicios exteriores han quedado fuera de este mundo. El viaje está por concluir al mostrarle su vejez, el fin de una vida lectora. ${ }^{14}$

Ese breve instante en que finaliza su vida y la saca del espejo de la lectura, ocurre en el momento que cierra los ojos. El espejo se cierra y la devuelve a la realidad externa que mira con ojos soñadores, como si aún no despertara del sueño. ${ }^{15}$

Hasta este momento hemos incursionado a una parte del mundo de las diversas lectoras, pero por qué es importante hablar de ellas. Las imágenes, sin ser espejo de la realidad, nos devuelven una representación de nuestra forma de ver la realidad. Al reconocernos en ellas, como mujeres nos permite comprender mejor nuestro propio universo femenino, abriendo con ello la posibilidad de dejar atrás los prejuicios históricamente

12 Ibid., ver del segundo 00:31 al segundo 00:44

13 Ibid., ver del segundo 00:45 al minuto 01:01

14 Ibid., ver del segundo 01:02 al minuto 01:12

15 Ibid., ver del segundo 01:13 al minuto 01:20 
heredados. Es importante resaltar que la lectura femenina no es diferente de la masculina, ambos experimentamos las mismas emociones, aunque las expresemos de diferente forma. De hecho, las imágenes de las lectoras son complementarias del universo masculino, en ellas se refleja la cultura de la que formamos parte y, por el efecto de inversión, nos devuelven la imagen de lo masculino. Las imágenes de las lectoras son el espejo de las de los lectores, en ellas, el mundo íntimo e interior, masculino y femenino, se conjugan provocando la ya mencionada mise en abîme que, si sabemos mirar, nos permitirá la construcción de un espacio en conjunto: es el coloquio universal de los lectores.

El espejo de la lectura refleja la belleza y gracia que puede construirse interiormente, pero la mirada elige lo que quiere ver. ¿Qué tiene que decir al respecto la ojeada bibliotecológica acerca de las imágenes de las lectoras? En principio, las imágenes como objetos de información, son fundamentales para entender el mundo visual en el que vivimos. Al conjuntar la lectura de la palabra escrita con el de la imagen podremos proporcionar los instrumentos para unir esos dos mundos y permitirle al lector, introducirse al mundo de la lectura sin riesgo a perderse entre discurso de la palabra y lenguaje de las imágenes. Atrevámonos a experimentar el placer de la lectura sin atavismos ni barreras, a experimentar la pasión de la lectura, caer en su hechizo a sabiendas de que el espejo perteneciente a la bibliotecología se abrirá para mostrarnos el camino de regreso. El espejo de la lectura está ahí, enfrentemos el reto de atravesarlo... 


\section{BIBLIOGRAFÍA}

Alfaro López, Héctor G., Introducción a la lectura de la imagen, México, DGB-UNAM, 2009.

Aumont, Jacques, La imagen, México, Paidós, 1992.

Baltrušaitis, Jurgis, El espejo, Madrid, Miraguano-Polifemo, 1978.

Bollmann, Stefan, Las mujeres que leen son peligrosas, Madrid, Maeva, 2006.

Carroll, Lewis, Alicia en el país de las maravillas y $A$ través del espejo, Barcelona, Edhasa, 2002.

Foucault, Michel, El cuerpo utópico. Las beterotopías, Buenos Aires, Nueva Visión, 2010.

- - - , Los espacios otros (trd. Luis Gayo Pérez Bueno). Acceso: 19 de agosto de 20013. Disponible en: https:// docs.google.com/document/d/1e_rh6BVLfRaG9akuHUAcxWYpplEIy7OZtO3wlmzxzUk/edit?hl=es\&pli=1

Gombrich, Ernst, La imagen y el ojo: nuevos estudios sobre la psicología de la representación pictórica, España, Paidós, 1987.

Joly, Martine, La interpretación de la imagen: entre la memoria, estereotipo y seducción, Barcelona, Paidós, 2003.

Mitchell, W. T. J., Teoría de la imagen, Madrid, Akal, 2009.

Parodi, Giovani (coord.), Saber leer, México, Aguilar, 2010.

Solana, Guillermo (director artístico), Heroínas. Catálogo de la exposición, Madrid, Museo Thyssen-Bornemisza y Fundación Caja Madrid, 2011. 
Wiertz, Antoine, La lectora de novelas, en Heroínas, Catálogo de la exposición, Madrid, Museo Thyssen-Bornemisza y Fundación Caja Madrid, 2011, 257 p.

\section{FUENTES EN INTERNET}

[Books and reading]: promo and feature presentation intro. En linea [Estados Unidos]: Showtime Beyond, 2008. Acceso: 3 de octubre de 2013. Disponible en: http://www.youtube.com/watch?v=CndQ-CXwnNY

Hussey, Tom, Reflections, Terra México. Acceso: 28 de octubre de 2013. Disponible en: http://vidayestilo.terra.com.mx/mujer/bienestar/reflections-serie-de-fotos-que-reflexiona-sobre-la-edad,97f6856246fd0410V gnVCM20000099cceb0aRCRD.html

[Mujer leyendo frente al espejo] en línea. En: Repule, Ilua. Jebkuram, kuru tas uztrauc. Otrā puse zemapzinain. Psihoanalīze. Atmošanās. Publicado el 21 de octubre de 2012. Acceso: 25 de octubre de 2013. Disponible en: http://ilure.livejournal.com/12875.html 


\title{
El mapa cuenta una imagen
}

\author{
TERESITA QUIROZ ÁVILA \\ Universidad Autónoma Metropolitana, \\ Unidad Azcapotzalco
}

\section{CIUDAD DE MÉXICO 1915}

a película El automóvil gris ${ }^{1}$ (1919) recrea los sucesos
verídicos de la temible banda de asaltantes dirigida por
Higinio Granda Fernández, la cual, asoló la ciudad de Mé-
xico en el año de 1915 , robando a ciudadanos ricos y viejos, re-
presentantes del sistema decimonónico, quienes guardaban su

1 Enrique Rosas, Joaquín Coss y Juan Canals de Homs, El automóvil gris. Los fotogramas que se incluyen en el texto forman parte de la edición conmemorativa de la película, realizada por la Filmoteca de la UNAM/DGAC en 2010; asimismo, cabe señalar que los datos históricos sobre el film y el contexto se han tomado del ensayo de Federico Dávalos Orozco, "En los tiempos del automóvil gris", que acompaña a dicha edición. La película era muda originalmente y años más tarde fue sonorizada.

La cinta muestra condiciones diversas de la vida capitalina: monumentos, arquitectura doméstica, transporte, oficinas gubernamentales, tiendas, mobiliario e infraestructura urbana, calles y avenidas con sus pavimentos y banquetas. Para los especialistas de la historia urbana, la fotografía de esta cinta es un documento formidable para conocer una imagen de la ciudad en el año 1919, año en el cual se rodó. 
fortuna (monedas de oro, joyas) en sus domicilios, debido a las condiciones de inestabilidad política y económica que se vivían en la capital. Tres sucesos acompañan la percepción de inseguridad que en ese año se experimentó en la ciudad y que la prensa registra: la ocupación zapatista, la instauración del carrancismo y la fuga masiva de presos en la cárcel de Belén.

La pandilla del auto gris trabajaba con un alto nivel de profesionalismo, cada golpe estaba perfectamente estudiado y utilizaban recursos novedosos para conseguir su objetivo, no solamente aprovechaban la situación de violencia existente sino que actuaban con tácticas innovadoras como delincuencia organizada, haciendo uso de elementos contemporáneos, los cuales, reflejan la modernidad de la época, además de tener cómplices entre las autoridades de la capital.

Uno de estos recursos novedosos que les permitía tener acceso al interior de los domicilios y con el cual se les distinguió, fue la vestimenta e identificaciones de militares carrancistas, así como documentación y órdenes de cateo oficiales. Los miembros de la banda se disfrazaban para presentarse ante sus víctimas como individuos autorizados para revisar las residencias, los disfraces sembraban falsas pistas en las personas perjudicadas, pues hacían creer que quienes agredían eran miembros del ejército, todo por el traje que portaban.

El automóvil, Overland modelo Turismo 86 descapotable de $1916,{ }^{2}$ es otro elemento de originalidad, un esplendido auto de color plomizo, el vehículo idóneo para que la banda se desplazara y permitera salir a mayor velocidad y seguridad del lugar asaltado; éste y su experimentado chofer, quien siempre los esperaba con el motor encendido justo para huir; fuer-

2 El automóvil de 1916, con la salvedad de producción que los hechos reales ocurrieron en 1915 y la película se filmó en 1919. Federico Dávalos Orozco, op. cit. 
za automotriz, que les da estatus de modernidad, pues en esa época los autos que transitaban por la capital pertenecían a la clase acomodada.

El tercer aspecto que da singularidad a la agrupación es el mapa; éste sirve para estudiar el terreno en el que se moverán en cada uno de los robos; cartografía que brinda la posibilidad de conocer rutas de movilidad para desplazarse por la ciudad.

A lo largo del film, aparecen dos documentos cartográficos en cuatro escenas.

\section{Fotograma 1}

Juramento de la banda, primera escena "Estaremos siempre unidos"



En la primera escena de la película, en el minuto dos (véase fotograma 1), los miembros pertenecientes a la banda se ponen de acuerdo para llevar a cabo sus planes de asalto, juran con las manos sobre el plano y una pistola que retóricamente apunta 
a la ciudad, al mapa. Dicen "Juremos que estaremos siempre unidos ante el peligro y la ley". No se observan características del plano. El mapa es testigo y cimiento de su juramento inicial, resulta una especie de cómplice de los atracos porque sobre él se organizan los movimientos de la banda, un registro que soporta toda la información del grupo delictivo.

Para el minuto (0:15:49) aparece un segundo mapa (véase fotograma 2), mismo que descuelga el jefe de la pared. Se observa que es de la capital, tiene divisiones administrativas por cuarteles que se indican con numeración en dígitos romanos y líneas obscuras que sobresalen, no se identifica título completo pero se pueden distinguir, con dificultad, las palabras Plano de ... y un subtítulo, así como coordenadas horizontales y verticales que caracterizan a ciertos planos de rutas de transporte. ${ }^{3}$ En éste se indica una dirección y ruta, el director de la banda da instrucciones "Mira, este es el camino de la calzada, llegamos hasta este lugar".

La tercera toma de un plano es en el minuto 43, aquí nos presenta otro mapa de la ciudad de México: un minucioso documento que muestra colonias, zonas urbanas y rurales de la demarcación y el perfecto trazo de las avenidas y calles de toda la capital (véase fotograma 3). Se observan cuarteles señalizados por diferentes colores y numerados en arábigos. El fotógrafo del film hace un acercamiento, el mapa se puede ver claramente; el jefe de la pandilla conoce las direcciones donde atacarán y las rutas que deben seguir para llegar al destino de su cometido, así, afirma: "por toda ésta avenida, hasta este punto es la casa del vejete", y su dedo va recorriendo la reproducción en miniatura de la que representa la avenida Refor-

3 Similar a otro mapa titulado Plano de la ciudad de México, de José Valente Baz, de 1923, con la leyenda que indica "el más moderno y completo con todas las calles y paradas de tranvías". 
ma hasta la esquina con la calle de Hombres ilustres. ${ }^{4}$ Calles y avenidas por donde se desplazarán, en su coche gris, son señaladas en el mapa para que sus colaboradores conozcan a la perfección el área donde actuarán.

\section{Fotograma 2}

Plano de la ciudad de México con referencia de cuarteles

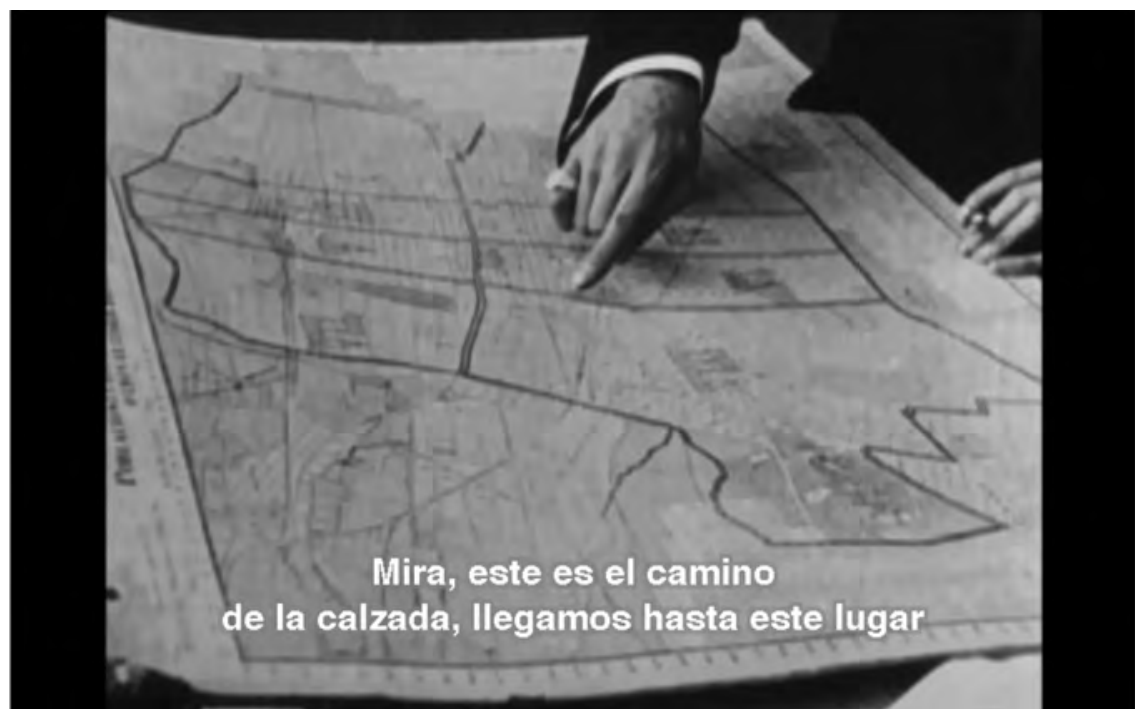

Cuarta toma, es el mapa intervenido (véase fotograma 3). Escena en el minuto 65, en la cual entra la policía a registrar la oficina de la pandilla, descubren evidencias y el mapa con senales que corresponden a las residencias que han sido asaltadas. Con un acercamiento de la cámara al documento, se puede identificar visiblemente el título Plano de la ciudad de México. $A \tilde{n} o$ 1915, un águila y en el margen superior el texto que dice "Las calles".

$4 \quad$ Escena de la película El automóvil gris (0:43:23).

5 Se refiere a otra escena de la película El automóvil gris (1:05: 40-42). 


\section{Fotograma 3}

Plano de la ciudad de México por colonias

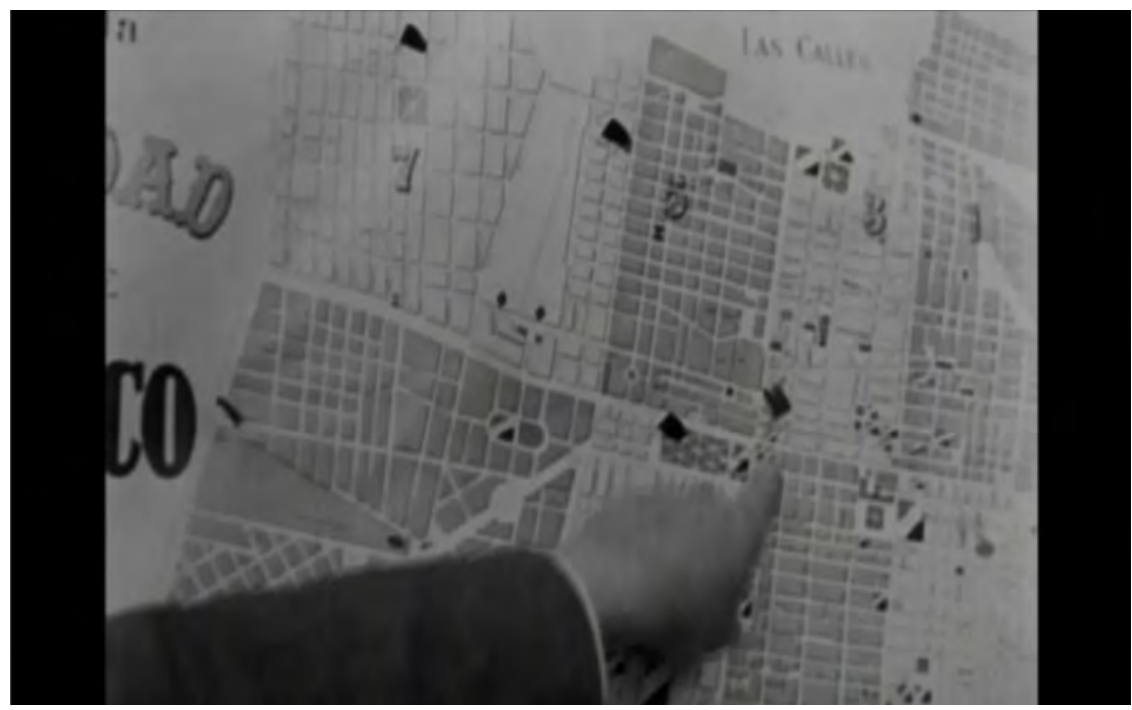

El mapa está señalado con distintivos obscuros que indican los lugares robados. Justo por eso es evidencia irrefutable, al dar testimonio de cada uno de los asaltos. Entonces el soporte de cartón pasa a ser una dermis en la que se van tatuando las claves, secretos y detalles del singular clan; una simple carta gráfica de la ciudad de México se convierte en el mapa de la banda, documento privado y secreto al mismo tiempo. Los malhechores lo han resguardado en la oficina hasta que es identificado por la policía, en el momento que irrumpen el centro de operaciones de la banda.

Como señala Kart Scholögel, "No hay guerra que empiece sin mapas, ni guerra que acabe sin ellos". ${ }^{6}$ En el caso de la

6 Kart Scholögel, "Tiempos de mapas. La época contenida en mapas”, En el espacio leemos el tiempo, p. 88. 
cinta, la guerra de la banda empieza sobre un mapa y termina con otro que los delata. Entonces, la pandilla será eliminada poco después que la policía descubre el plano con los lugares atracados.

\section{Fotograma 4 \\ Mapa para análisis}

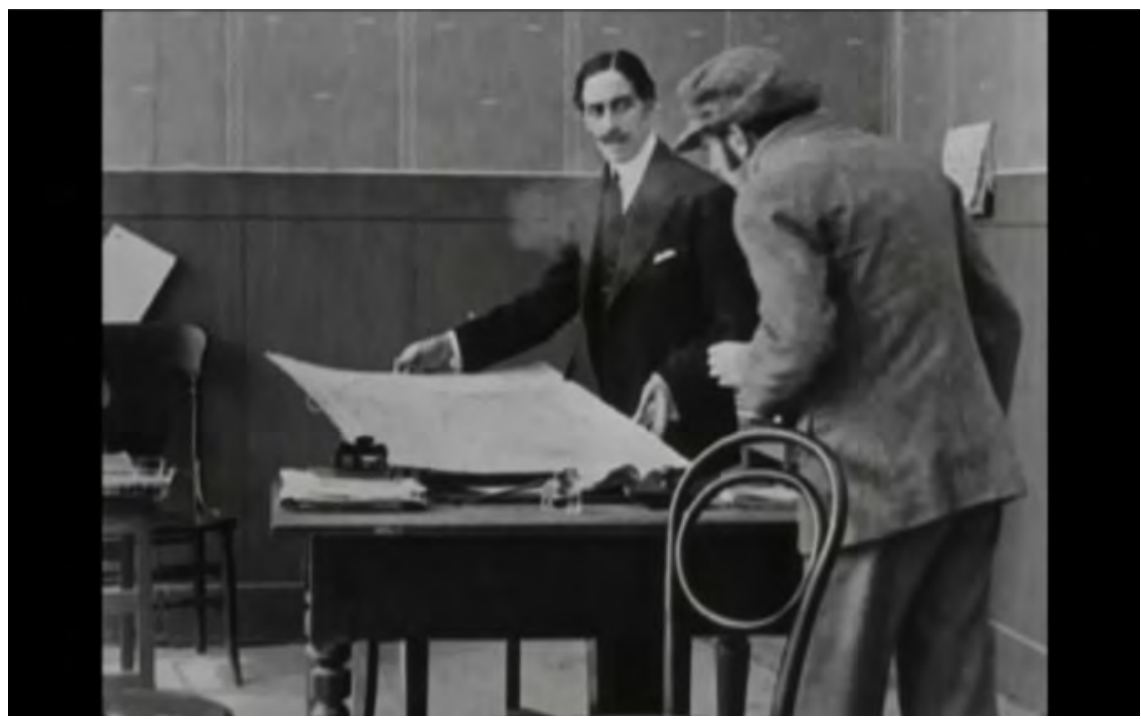

El texto gráfico ha sido manipulado por sus usuarios, va de la pared de la oficina, donde está colgado al escritorio, y mesa de análisis (véase fotograma 4); para los miembros de la banda es objeto de uso donde ubican sitios específicos y rutas a seguir. El texto mapa es reflejo de una intencionalidad como consecuencia de las necesidades particulares de quienes lo utilizan, pues los sujetos que lo usan imprimen una significación determinada al documento, en este caso el espacio de sus robos a la propiedad privada. 
A la intención sigue el marcaje o ubicación de coordenadas en el mapa, aquí es el momento en que se da la intervención, todo objeto que es intervenido sufre una transformación, sobre la base cartográfica original, se colocan puntos de referencia que tienen relevancia y quedan como banderas emblemáticas sobre el mapa, con lo cual, se suman nuevos elementos al gráfico primario. En conjunto, las marcas de la intervención dan un nuevo significado al mapa primigenio, los registros sobrepuestos muestran la ubicación de lugares específicos que cobran sentido por la intención de los sujetos que manipulan el plano. Esta segunda información nos muestra un espacio delimitado dentro del mapa de la ciudad; como resultado de la anotación de direcciones se va conformando un patrón capitalino de sitios de riqueza que indica las posiciones urbanas de ciertos personajes acaudalados. El mapa de la banda es una especie de cala con la cual se penetra y realzan ciertos aspectos del territorio y, como toda hendidura, muestra un área sensible en el terreno que puede ser decodificada por quienes la leen: asaltantes y policías. Así, como las muñecas rusas matruzkas, existe un mapa dentro de un mapa.

En un solo documento intervenido, se aglutina toda la historia de la pandilla. El mapa de la banda es el repertorio de una temporalidad sui generis que indica los movimientos del grupo, desde el primer atraco efectuado y los consecutivos, hasta el momento en que tienen que escapar de la policía. Es pasado y futuro. En un mismo plano se conjuntan tiempos, lugares y movimientos, espacio en acción. Toda una historia que nos narra el mapa en las coordenadas: ciudad de México 1915, asaltos e inseguridad urbana.

En este sentido me interesa rescatar la reflexión de Georges Didi-Huberman, quien señala que la imagen arde con: lo real, por el deseo, la destrucción, por el resplandor que produce, por su intempestivo movimiento, por su audacia y por la memo- 
ria que revive, es una huella con tiempos complementarios que en calidad de arte de la memoria no puede dejar de aglutinar gran cantidad de información, la cual, hay que escudriñar:?

Pero, para saber todo esto, para sentirlo, es preciso atreverse, es preciso acercar el rostro a la ceniza. Y soplar suavemente para que la brasa, por debajo, vuelva a producir su calor, su resplandor, su peligro. Como si, de la imagen gris, [de un simple mapa] se elevará una voz [que dice]: “№ ves que estoy en llamas?"

Se percibe el incendio, el peligro que se sufre con la cotidiana inseguridad que se vive en la urbe capitalina. La película lo demuestra, y el mapa tal documento signado como huella, acontecimiento y permanencia, lo captura y codifica la evidencia. En una narrativa cinematográfica de vanguardia, el director Enrique Rosas nos lleva de los espacios interiores y privados a los exteriores públicos de la ciudad y nos hace observar una selección amplia de ambientes urbanos. Nos enseña la calle en dos niveles: la que se representa dibujada en el plano y la que podemos denominar como real habitada. Así dinamiza una lectura que propone al espectador de la cinta y la cual indica que el mapa es igual a la ciudad, pero que a través del plano se pueden conocer y estudiar las vías para saber llegar a un destino determinado.

Los espacios exteriores que se recogieron en las tomas fílmicas nos sirven para observar las condiciones reales del año en que se realizó el rodaje (1919), en ellas se encuentran las calles de la capital y diferentes barrios, en particular las inmediaciones de los lugares de asalto. Se pueden observar los sitios asaltados, por ejemplo, la casa del señor Martel ubicada en la calle del Álamo; en esta secuencia observamos el tipo de ban-

7 Georges Didi-Huberman, Arde la imagen, p. 42.

8 G. Didi-Huberman, op. cit., p. 43. 
quetas con piedra laja y el empedrado de la vía donde transitan los transportes.?

\section{Fotograma 5}

Calle de Álamo, se observa en la placa de nomenclatura. Casa de una planta, ventanas con balcón y banqueta

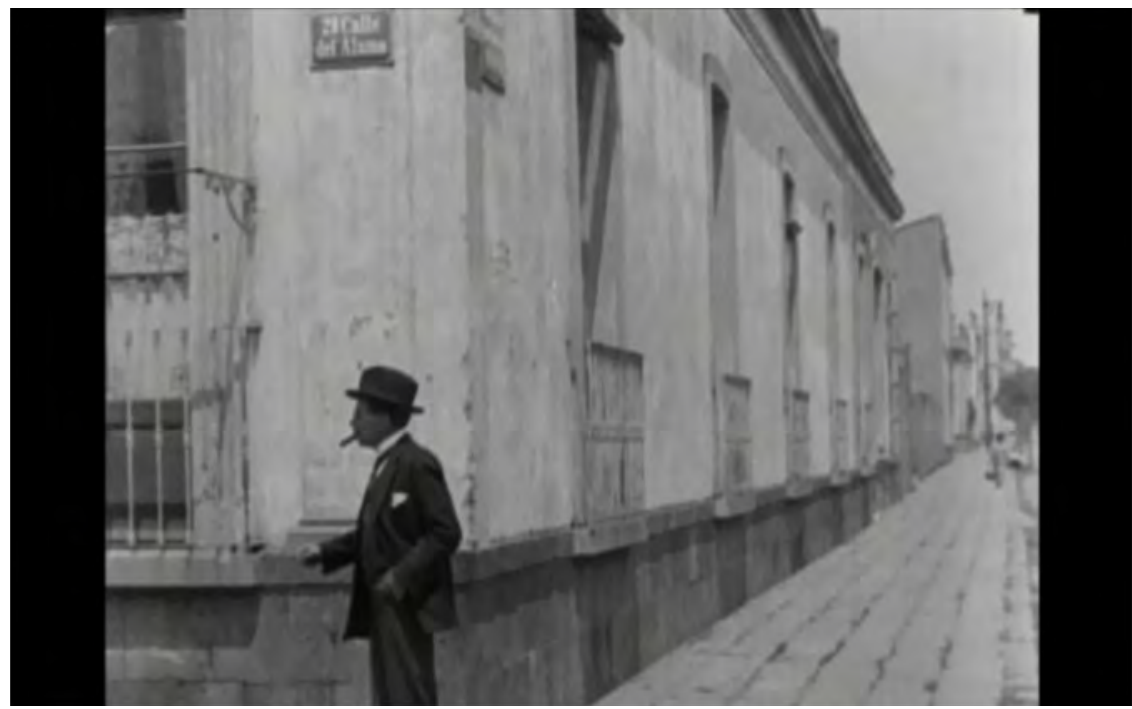

La trama ubica a los asaltantes frente a la puerta de dos residencias en las cuales se observa claramente el número 47 y 163, en la primera fotografía el atraco ha sido consumado, en la segunda imagen el grupo está por iniciar su violación domiciliaria (véanse fotogramas $7 y 8$ ).

Se pueden observar elementos urbanos como banquetas amplias de adoquín con árboles jóvenes; calles anchas de terracería, pavimento o empedrado; postes de alumbrado y teléfono; infraestructura de drenaje; casas de uno y dos niveles, con

9 Propietarios asaltados: dos mujeres (casa de la Piedad), Vicente González, Toranzo, Martel (calle del Álamo 47) y Mancera (número 163). 


\section{Fotograma 6}

Calle de Álamo, se observa casa de una planta, ventanas con balcón y el negocio vecino de "forrajes", banqueta y calle, de piedra laja y empedrado

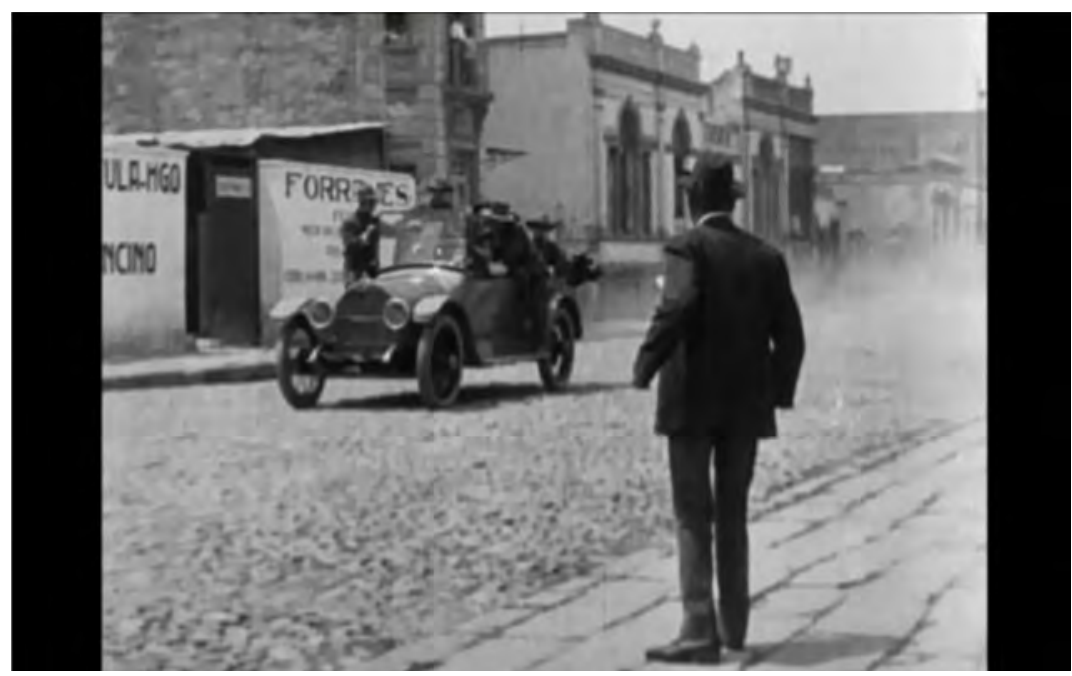

Fotograma 7

Álamo número 47




rejas y jardines internos; en las inmediaciones se observan viviendas de medio y alto nivel económico, baches, así como terrenos fraccionados sin construir (véanse fotogramas 10, 11 y 12). Otros importantes sitios urbanos que aparecen en la película son: el cine Olimpia, la estación de trenes de La Villa, las glorietas de El Caballito y de Cuauhtémoc, así como una tienda con el rótulo "El triunfo de San Rafael".

\section{Fotograma 8}

Residencia con el número 163






\section{Fotograma 9}

Baches en avenida con pavimento de asfalto, policía vecinal y perro callejero

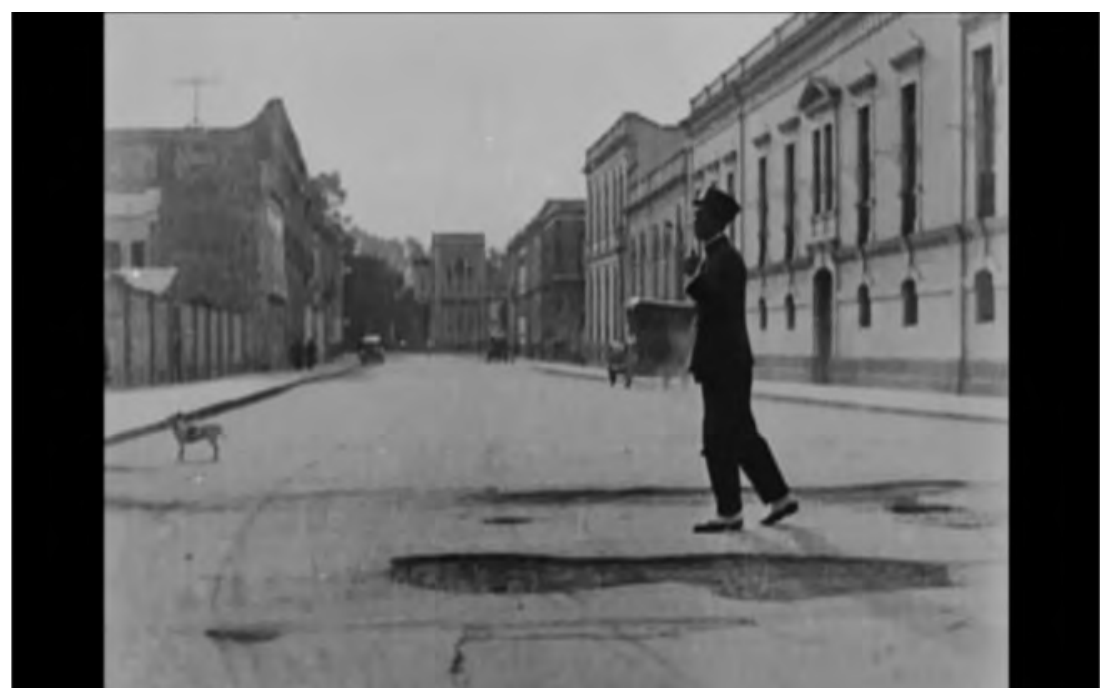

Fotograma 10

Arbolado joven, atarjeas, postes de teléfono y luz eléctrica

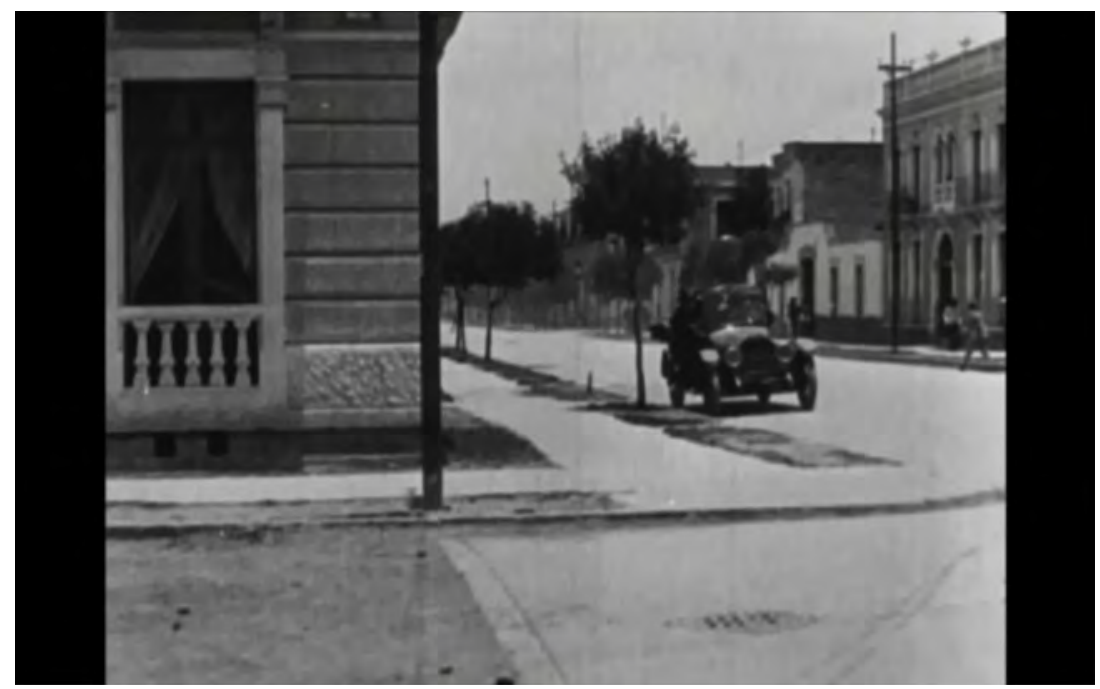




\section{Fotograma 11}

Banquetas nuevas sin arbolado, calles sin pavimentación, terrenos fraccionados sin construcción



\section{EN LA BÚSQUEDA DEL MAPA DE PAPEL}

El campo de estudio es muy amplio, porque demandan ser investigados tanto aspectos teóricos como problemas prácticos de la disciplina, pero también de las instituciones propias al proceso de la información, de los servicios bibliotecarios y de información; algunos de ellos: el acopio de la información, su organización, almacenamiento y diseminación, así como el para qué, el porqué, el cómo y el para quién se genera la información, su comportamiento, su uso y sus medios de comunicación.

Estela Morales

La biblioteca es un lugar de resguardo de algunos documentos, la carta gráfica de la ciudad de México de 1915 que utiliza Enrique Rosas en su cinta de 1919, no aparecía en ninguna ma- 
poteca, de acuerdo con una búsqueda realizada, a través de los archivos digitales de distintas instituciones. Varias cartografías ya no existen en su soporte original y las podemos encontrar, como es el caso, siendo parte de otro discurso más complejo y en un soporte distinto, ¿cómo van los usuarios de la biblioteca a tener referencia de este documento del que no se cuenta con la evidencia material en el soporte original: me refiero al mapa de papel? La respuesta es ya obvia: la película, en su formato digital (DVD), soporte que actúa como archivo de resguardo del material cartográfico, espacio que ha dado guarida a la imagen recreada de la ciudad de 1915 (según la saga de la banda del auto gris): una película que guarda los sucesos de la capital, una ciudad de 1915 en una de 1919, que contiene planos y a su vez contiene el mapa de la banda del automóvil gris. Los mapas de la ciudad que aparecen en dos versiones (1915 por colonias, cuarteles) ¿será un error de producción?, lo cierto es que un aparente dislate se convierte en un elemento delicioso para ver planos.

¿Pero, si nos interesan los mapas, dónde quedan clasificados estos planos: en filmoteca o en cartografía? ¿Dónde se resguarda la imagen-mapa que está en una película?. Seguramente, lo correcto será que exista una referencia cruzada, para que los seguidores de planos disfruten el uso del mapa que tiene su permanencia en otro soporte. Un reto divertido a realizar entre bibliotecarios y buscadores de ciudades perdidas, ahora, cartógrafos que navegan en mares fílmicos. ${ }^{10}$

10 Cabe señalar que la reflexión se mantiene, pero la investigación toma un nuevo rumbo, debido a que encontré un ejemplar original del Plano de la ciudad de México 1915. Este documento expuesto en la exposición "Arquitectura en México (1900-2010). La construcción de la modernidad. Obras, diseño, arte y pensamiento". Palacio de Cultura Banamex (Palacio de Iturbide), diciembre 2013 a julio 2014. El Plano ubica las colonias de la capital en distintos colores y en una leyenda que señala: Grabado con acabado en tinta. Solicite el instructivo anexo. El estudio de esta cartografía será un trabajo que se realice en el futuro y que por el momento rebasa los tiempos y objetivos que nos propusimos para la escritura de este ensayo. 


\section{PERMANENCIA Y AUSENCIA}

Ideas que permanecen en imaginarios transitando en el tiempo, razonamientos insustanciales resguardados en diferentes recipientes: escritos, costumbres, recetas, historias contadas y pintadas. Evidencias materiales de una época a otra, guardadas entre escombros olvidados; reliquias del pasado que se mantienen en la cotidianeidad. Su origen se ha olvidado, se ausentó, sin embargo, permanece en piezas, objetos complejos de cal, argamasa y materiales tatuados de simbolismos, edificios, calles, fotografías; materialidades diversas en soportes múltiples, analógico o digitales. El mapa permanece en la película y al mismo tiempo nos marca su ausencia en papel.

Permanecer es el verbo, la acción de mantenerse (eterno o en proceso), el sustantivo es la permanencia, aquello que existe, que se queda, la sustancia y la evidencia de perdurar. $^{11}$

Por eso, en contrapartida y en complemento de la permanencia, está la ausencia, la carencia del todo: el cambio. Entre estos contrarios se establece una tensión con límites casi invisibles. Permanencia es algo que se mantiene, está en constante lucha por no desaparecer y vive un proceso de resistencia donde se resignifica para continuar ante el embate de ser borrado o diluido por la ofensiva del tiempo o la fuerza del poder. En lo ausente encontramos algo que se ha ido, la muestra de lo que fue y dejó un lugar de un otro el cual existía, previo al vació estuvo un todo que al marcharse produjo una huella, una muestra que deja ver una sombra, un rescoldo de alguna gran hoguera

11 Ya en la antigüedad el filósofo Parménides se refería a permanecer como el ser en estabilidad, eterno, inamovible, único, la razón como una sola, el ser sobre todas las cosas. Para Heráclito la permanencia debe entenderse como el principio de todas las cosas "Arje": el constante cambio, lo cual, propicia la dinámica de movilidad, del proceso, del devenir, lo que sucede, lo que hace que el ser sea, la lucha de los contrarios. 
la cual antes estuvo encendida. Un mapa ausente que ha dejado marca y que se impregnó en una película sobre el asalto a la urbe. Una representación gráfica de la ciudad que se mantiene por su presencia como objeto de una historia contada en el cine, existe el discurso mapa pero no en su característica original, creando una ausencia de material primigenio pero permanencia que nos dice que era ese plano y no otro.

Ideas y objetos están ahí sin ser vistos, no recobran su cuerpo hasta que son descubiertos y decodificados por un personaje que reorganiza la sustancia de su origen, el proceso de su olvido, quien desvela y revela su permanencia pero también su ausencia.

Revisemos las consideraciones de Ignasi de Solà-Morales respecto al lugar como permanencia o producción. ${ }^{12}$ Con la advertencia que él lo hace desde la arquitectura, sin embargo, su propuesta nos ayuda a reflexionar sobre el lugar y la permanencia. En la primera parte de su artículo "Anywhere", hace una interesante revisión de las corrientes filosóficas y arquitectónicas para señalar cómo se ha utilizado y modificado la noción de espacio y lugar en el siglo XX, el cual, va de los presupuestos de la fenomenología y la percepción del espacio, hasta la arquitectura como lugar en cierto entorno. En la segunda parte, formula la pregunta ¿qué es un lugar? refiere la noción de permanencia. ${ }^{13}$ Se apoya en la pregunta que Michael de Certeau se hace sobre ¿qué es un lugar?

Solà-Morales recupera las ideas de lugar y tiempo imbricados, marcados por las culturas históricas que pretenden man-

12 Ignasi Solà-Morales, "Anywhere. Lugar: permanencia o producción”, Los artículos de Any, FQ, pp. 35-46.

13 Claramente ha retomado los trabajos de Michael de Certeau y Marc Augé sobre habitar, lugar y no lugar. Marc Auge profundiza desde el concepto de lugares y no lugares para entender a la ciudad como un lugar que está ahí y el mapa utilizado, posiblemente, como un no lugar que se ejerce pero que está en tránsito. Marc Augè, "Lugares y no lugares". 
tener su identidad y luchan contra el paso del tiempo, un sitio en tensión que trata de mantenerse igual pero otras fuerzas le obligan a cambiar. A esta concepción de lugar y tiempo históricos se suma la cultura del acontecimiento, que trata de encapsular la realidad del presente y proyectarse al futuro, para quedar como evidencia de su época "Lo que era many, se repliega en un Any que puede detenerse en un one". ${ }^{14}$ Las características del acontecimiento son: permanencia, punto de encuentro y prehensión. Así, la evidencia de lo que sucede se mantiene como onda sonora o luminosa, permanece tal vibración antes de disiparse. El acontecimiento, también denominado como buella, es punto de encuentro entre diversos elementos: tiempo, energía, creación, condiciones propicias para la construcción, ubicación en el espacio y producción de un lugar específico (la ciudad asaltada). La otra particularidad, es la acción subjetiva de asombro, ésta se genera por una atracción del acontecimiento que conmueve al sujeto investigador, quien promueve un gozo y una frágil plenitud, atravesando por un estado de sublimación en consecuencia de la experiencia estética que vive el individuo.

Es como un acorde extensivo, como una intensidad en un cruce energético de los flujos comunicativos, como una subjetiva prensión que [el investigador] ofrece en la alegría de producir un instante polifónico en el seno del caos de las macropolis. ${ }^{15}$

Así, el acontecimiento es la producción de un otro que es la evidencia de una época, esta construcción no es permanente en tanto inamovible o eterna, es realizar un algún, lo único, que hace indudable un tiempo determinado, que hace permanente un punto en el espacio tiempo y contiene el espíritu de su épo-

14 Ignasi de Solà-Morales, op. cit., p. 36.

15 Op. cit., p. 40. 
ca. El mapa es discurso que aglutina acontecimiento: la ciudad de 1915 asaltada por la inseguridad de la banda, el cual, es la evidencia de su tiempo. ${ }^{16}$

\section{BIBLIOGRAFÍA}

Atienza, Ricardo. "Ambientes sonoros urbanos: la identidad sonora. Modos de permanencia y variación de una configuración urbana", Encuentro Iberoamericano sobre paisajes sonoros, Madrid, Centre de recherche sur l'espace sonoro et l'environnement urbain, Cresson, 2007.

Augè, Marc. "Lugares y no lugares". Los "no lugares" Espacios del anonimato, España, Gedisa, 1998.

Didi-Huberman, Georges, Arde la imagen, México, Serieve, 2012.

Lacerda, Norma, Lucial Eitao, Paulo La Biliares Queiroz, "Espacio de legitimidad: una discusión de mutación y permanencias de las estructuras espacial urbana". en Eure, volumen 36, número 107, Brasil, abril 2010, http://www.scielo. $\mathrm{cl} /$ pdf/eure (consultado 20 septiembre, 2013).

16 Algunos autores para el estudio de lo urbano, retoman la noción de permanencia, por ejemplo Ricardo Atienza desde el análisis de los sonidos urbanos revisa la idea de permanencia de resonancias características de los lugares a través de lo que denomina continuo sonoro: ecos diversos como voces, pregones, campañas, transportes, fábricas que dan identidad a la cotidianeidad y generan ambientes auditivos. Ricardo Atienza, "Ambientes sonoros urbanos: la identidad sonora. Modos de permanencia y variación de una configuración urbana”. Norma Lacerda con otros especialistas brasileños mantuvieron en 2010 una discusión sobre la mutación y la permanencia de las estructuras urbanas como espacio de legitimidad; donde planteaban la dinámica social de pobladores, grupos inmobiliarios y políticas gubernamentales al momento en que se modifican espacios patrimoniales, lo que genera una cohesión social: la persistencia versus la trasformación de estilos de vida y condiciones territoriales. Norma Lacerda, Lucial Eitao, Paulo La Biliares Queiroz, "Espacio de legitimidad: una discusión de mutación y permanencias de las estructuras espacial urbana”, pp. 109-122. 
Valente Baz, José, Plano de la ciudad de México de José Valente Baz de 1923: el más moderno y completo con todas las calles y paradas de tranvías, México, J. V. Baz, 1923.

Plano de la ciudad de México 1915, [Grabado con acabado en tinta] Colección del Museo de la Ciudad de México, Gobierno del Distrito Federal.

Rosas, Enrique (dir.); Joaquín Coss y Juan Canals de Homs, $E l$ automóvil gris, México, Imperial Cinematográfica, ed. conmemorativa realizada por la Filmoteca de la UNAM/DGAC, 2010 [1919]. Incluye el ensayo "En los tiempos del automóvil gris”, de Federico Dávalos Orozco, Centro de Estudios de la Comunicación, Facultad de Ciencias Políticas y Sociales de la UNAM, México, 2010.

Scholögel, Karl. "Tiempos de mapas. La época contenida en mapas”, En el espacio leemos el tiempo, Barcelona, Siruela, 2007.

Solà-Morales, Ignasi, "Anywhere. Lugar: permanencia o producción”, en Los artículos de Any, FQ, (Colección La cimbra 7). 


\section{RELACIONES ENTRE LA CULTURA ESCRITA Y LA CULTURA VISUAL}




\title{
Presentación
}

\author{
EMILIO RAMÍREZ CRAVO \\ Dirección General de Bibliotecas \\ de la UNAM
}

todo lo largo del siglo xx se evidenció la potencialidad
del cine como forma de expresión y transmisión de ideas.
Ya sea que se trate de filmes de corte documental, artístico, comercial o denuncia social, el cine es portador de un tipo singular de información: imagen en movimiento y sonido se conjugan para conformar un discurso audiovisual. Sin embargo, identificar, describir y analizar los elementos que forman parte del lenguaje cinematográfico son tareas que no siempre han sido abordadas en el ámbito bibliotecológico mexicano. Luis Iturbe nos presenta una metodología de lectura basada en el análisis textual y enfocada en las dimensiones psicológica y social de la bibliotecaria Alicia Hull, en la obra cinematográfica "El Ojo del Huracán”.

El acercamiento lúdico y reflexivo de la intervención de Emilio Chapela nos remite, desde una propuesta estética, a preguntarnos sobre la naturaleza y sentido de la información en nuestro tiempo. ¿El fin del libro impreso? ¿El ocaso de las bibliotecas? ¿Cultura impresa vs cultura digital? Siguiendo, además, la idea 
de Walter Benjamin acerca del desvanecimiento del aura mediante la multiplicación masiva del objeto libro, juega también con el paso de lo analógico a lo digital al documentar mediante fotografías los errores en el proceso de digitalización de los libros que conforman la colección de Siqueiros. Es así que través de la réplica en madera de la biblioteca de David Alfaro Siqueiros y su identificación temática mediante colores, que el artista nos pone de manifiesto la situación actual de la cultura impresa, sus límites y su porvenir.

Los lenguajes documentales son una herramienta esencial para describir el contenido temático de los documentos en el ámbito bibliotecológico. Sin embargo, las reflexiones acerca de su origen, función y uso cobran vital importancia al enfrentarnos a la lectura de la imagen como objeto de estudio en la bibliotecología. ¿Cumplen su función de representatividad? ¿Cuáles son sus alcances y posibilidades? A través de un ejemplo concreto, Catalina Pérez nos presenta las características, particularidades y dificultades al realizar el análisis documental de un grabado del siglo XVIII, basando su ejercicio en el método iconológico de Erwin Panofsky y mostrando cómo se puede integrar este método, propio de los estudios de historia del arte y la Iconología, como una alternativa dentro del análisis documental.

Desde diferentes soportes y con distintos acercamientos, los análisis y reflexiones aquí presentes muestran una parte de la riqueza y variedad que los estudios sobre la lectura de las imágenes aportan a la disciplina bibliotecológica. Por otro lado, también queda implícita una cuestión de mayor envergadura: la necesidad de contar con herramientas teóricas y conceptuales que permitan abordar la imagen y su lectura desde el campo bibliotecológico, tarea que requiere volver a pensar en los fundamentos mismos de la disciplina, con un enfoque crítico, propositivo y renovador. 


\title{
Hacia una lectura estructurada de la obra cinematográfica: El ojo del huracán
}

\author{
LUIS RAÚl ITURBE FUENTES \\ Janium Technology
}

The historical fact is that cinema was constituted as such

by becoming narrative, by presenting a story, and by rejecting its other possible directions. The approximation

which follows is that, from that point, the sequences of images and even each image, a single shot, are assimilated to propositions or rather oral utterances [...].

Gilles Deleuze

\section{INTRODUCCIÓN}

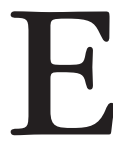

n el campo bibliotecológico, las imágenes cinematográficas son estudiadas desde el soporte que las almacena y bajo la óptica de la palabra escrita. Los significados de la imagen, en este sentido, se reducen y circunscriben al estudio canónico de la cultura impresa, lo que origina una distorsión cognitiva, ya que se intenta convertir a la imagen en algo ajeno a sus características inherentes.

La lectura de la imagen cinematográfica, en este sentido, ha sido poco estudiada, puesto que, por una parte, se considera 
que la imagen es para ser ver, mas no leer y, por otra, ésta se relaciona con el entretenimiento, aun cuando es una fuente de información y de conocimiento, ávida de su lectura. Por ello, en este artículo se estudia al cine y, por ende, el filme como obra cinematográfica. ${ }^{1}$ Ésta puede leerse como texto en términos de códigos que forman asociaciones y relaciones significativas con situaciones de la vida real, con obras literarias y, como señala Zavala, con otras obras cinematográficas. ${ }^{2}$

La lectura, por tanto, ha dejado de ser meramente textual, como señala Roland Barthes, "no hay pertinencia de objetos: el verbo leer, se leen textos, imágenes, ciudades, rostros, gestos, escenas, etc."; ${ }^{3}$ ya que el objeto que uno lee se fundamenta tan sólo en la intención de leer. Lo que se lee es la representación de algo, las personas reciben, decodifican, asimilan y construyen sentidos y significados de distintos tipos de información, entre ellos, las imágenes cinematográficas difundidas a través de diversos medios de comunicación.

En las obras cinematográficas, la narración relata o comunica información sobre una historia que le sucede a un personaje en un determinado ambiente; y estos hechos son representados mediante el discurso cinematográfico que la transmite por medio de un lenguaje audiovisual, el cual, constituye una "representación visual que posee cierta similitud o semejanza con el objeto al que representa". ${ }^{4}$ En este campo, representar está asociado con evocar por descripción, retrato e imaginación

1 Luis Raúl Iturbe Fuentes, Indización de la cinematografía basada en la intertextualidad. Tesis de licenciatura en Bibliotecología, y Luis Raúl Iturbe Fuentes (a), Las representaciones del bibliotecario en el discurso cinematográfico, Tesis de maestría en bibliotecología.

2 Lauro Zavala, Elementos del discurso cinematográfico, pp. 101-102.

3 Roland Barthes, El susurro del lenguaje: Más allá de la palabra y de la escritura, p. 41.

4 María Acaso, El lenguaje visual, p. 23. 
y con situar semejanzas de algo ante la mente o los sentidos. ${ }^{5}$ En este proceso interviene una realidad, el emisor que hace la representación de cierta realidad en determinado contexto, y el receptor o espectador que interpreta esa representación con ciertos significados culturales y sociales.

De esta manera, el cine asigna a sus personajes características y comportamientos a partir de la concepción cultural y social de la imagen cinematográfica, la cual, se constituye a partir del producto de un aparato técnico que reproduce y representa con exactitud y objetividad varios niveles de la realidad, que se presentan con un sentido determinado, realidad material con valor figurativo, realidad estética con valor afectivo e intelectual con valor significante. ${ }^{6}$

Entre los diversos personajes de la cinematografía, el bibliotecario ha sido representado en diferentes géneros cinematográficos a lo largo del siglo XX. En torno a la representación del bibliotecario en el cine, se han realizado diversos estudios que analizan la caracterización del personaje en los filmes, debido a que un tema de discusión e interés entre bibliotecarios es entender cómo su imagen estereotipada se ha perpetuado en el cine, ha repercutido en su estatus, su reconocimiento social y escasa visibilidad de su actividad profesional.

Cabe destacar que algunos argumentos cinematográficos están basados en la literatura, otros, adaptados de obras de teatro, y algunos de personajes de la vida real, como el filme $E l$ ojo del buracán (Storm Center). En relación con lo anterior, este trabajo busca aplicar una propuesta metodológica de lectura y análisis del discurso cinematográfico para examinar la representación del bibliotecario como personaje en este filme.

5 Santos Zunzunegui, Pensar la imagen, p. 13.

6 Marcel Martin, El lenguaje del cine, pp. 27-32. 


\section{MÉTODO}

La lectura del discurso cinematográfico sigue dos ejes: primero, el análisis textual mediante la segmentación y sistematización del filme para identificar y examinar los elementos del discurso cinematográfico ${ }^{7}$ que caracterizan la representación del bibliotecario ${ }^{8}$ el segundo, el análisis del personaje, desde la narración, enfocado en aspectos psicológicos y sociales de la figura en cuestión.? La aplicación de la metodología perteneciente a la lectura del discurso cinematográfico del personaje del bibliotecario en el filme El ojo del huracán, conllevó lo siguiente:

1. Selección del filme: El ojo del huracán, el cual, cumple con los siguientes criterios.

- En la trama está caracterizado un bibliotecario como personaje principal o personaje secundario.

- Las características psicológicas (personalidad) y sociales del personaje del bibliotecario son visibles.

- En la narración se presenta el rol del bibliotecario.

- La trama hace referencia a actividades profesionales del bibliotecario (directivo o responsable, asistente de biblioteca, etc.).

- Las actividades bibliotecarias están presentes más de una vez en la narración del filme.

2. Descripción de los elementos de la obra en una ficha técnica y elaboración de sinopsis del filme que plantea los componentes centrales de la narración enfocada en el personaje del bibliotecario.

$7 \quad$ Op. cit., Zavala, pp. 101-102.

8 La representación de personajes deriva del imaginario social, mismo que se conforma por contenidos conceptuales (información, símbolos, valores, opiniones) establecidos por un sujeto (sociedad) en relación con un objeto social.

9 Federico Franceso Casetti y Federico Di Chio, Cómo analizar un film, p. 171. 
3. Segmentación del filme, mediante un recorrido lineal para dividirlo en secuencias, como unidades breves de contenido, lectura y análisis, tanto para describir las escenas en las que aparece el personaje del bibliotecario, como para identificar las cuatro secuencias representativas de la narración: a) Presentación del personaje b) Problema de la trama, c) Transformación del personaje y d) Solución del problema.

La segmentación consiste en explorar cómo se organizan y se distribuyen la trama y el argumento para determinar y describir las secuencias del filme, que es el contexto en el que se identifican las características del personaje del bibliotecario y su ambiente en la narración. ${ }^{10}$

4. Elaboración de un mapa del personaje para el análisis de su ambiente, la acción que se realiza y los diálogos que están presentes en las secuencias. Este proceso de estratificación responde a la pregunta ¿Qué distinguir en el interior del filme?

La estratificación consiste en la elaboración de una representación gráfica de componentes internos simbólicos de la narración -el bibliotecario (sus características) y el ambiente que sitúa las escenas (biblioteca, libros, sala de lectura, etc.)- para identificar de manera transversal los elementos (homogéneos o heterogéneos) presentes en las secuencias. ${ }^{11}$

5. Elaboración, por igual, de elementos simbólicos de la narración que enumera los atributos del personaje del bibliotecario en sus dimensiones psicológica y social. La enumeración de elementos lleva a delinear un primer mapa del personaje del bibliotecario y su ambiente que

10 Op. cit., Cassetti, p. 38.

11 Ibid., pp. 44-45. 
posibilite interpretar diferencias y semejanzas en las dimensiones, buscando la reconstrucción de un cuadro global que establezca relaciones y la representación sintética de los componentes de identidad y rol del personaje así como el ambiente, presentes en secuencias y escenas de la narrativa. ${ }^{12}$

a) La dimensión psicológica comprende el análisis de caracterización del personaje y de emociones expresadas. Los rasgos de personalidad interpretados por el personaje en la narración y discurso cinematográfico se agrupan en cinco categorías: estabilidad emocional, apertura, amabilidad, responsabilidad e interacción social. El análisis de emociones que expresa el personaje en las secuencias representativas son: sorpresa, miedo, disgusto, cólera, felicidad, y tristeza. Los elementos del personaje en el discurso cinematográfico se identifican mediante la observación facial en su caracterización. ${ }^{13}$

b) En la dimensión social se identifican las siguientes categorías: estado civil, nacionalidad, clase social, educación, profesión, actividades y funciones profesionales que se reflejan en los filmes. No obstante, la reagrupación social del personaje del bibliotecario se enfoca en las siguientes categorías para, posteriormente, contrastar y analizar la representación: el rol narrativo del personaje (relevancia y focalización del bibliotecario), el análisis de la clase de acciones del personaje en la trama y las actividades profesionales que desempeña en la trama. ${ }^{14}$

6. Análisis de la caracterización psicológica y social del personaje del bibliotecario.

12 Ibid., p. 49.

13 Op. cit., Iturbe Fuentes (a), pp. 50-52, 54-57.

14 Ibid, pp. 53-54. 
En este proceso de reagrupación, la narrativa se organiza a partir del concepto de las situaciones, que en el texto están constituidas por las relaciones de personajes (quiénes), acciones (qué hacen), objetos (para qué o con qué motivo), tiempo (cuándo) y espacio (dónde).

\section{APLICACIÓN DE LA METODOLOGÍA DE LA LECTURA DEL DISCURSO CINEMATOGRÁFICO EN EL FILME}

\section{Descripción del filme}

\section{Ficha técnica}

\begin{tabular}{|l|l|}
\hline Elementos & \\
\hline Título & El ojo del huracán (Storm Center) \\
\hline Producción & Julian Blaustein Productions \\
\hline País & Estados Unidos \\
\hline Año & 1956 \\
\hline Duración & 85 min. \\
\hline Color & Blanco y negro \\
\hline Género & Drama \\
\hline Director & Daniel Taradash \\
\hline Productor & Julian Blaustein \\
\hline Guionista & Elick Moll, Daniel Taradash \\
\hline Fotógrafo & Burnett Guffey \\
\hline Músico & George Duning \\
\hline Editor & William A. Lyon \\
\hline Actores & $\begin{array}{l}\text { Bette Davis (Alicia Hull), Brian Keit (Paul Duncan), } \\
\text { Kim Hunter (Martha), Paul Kelly (Robert Ellerbe) }\end{array}$ \\
\hline Idioma & Inglés \\
\hline
\end{tabular}




\section{Sinopsis del filme: El ojo del huracán}

Alicia Hull (Davis) es la bibliotecaria de un pequeño pueblo, quien está interesada en promover la lectura en los niños. El Consejo Público le pide descartar el libro El Sueño Comunista de la colección de la biblioteca, a fin de contar con apoyo para la construcción de una sala infantil de lectura. Debido a que Alicia Hull se rehúsa a cumplir con esta exigencia, no sólo es despedida, sino etiquetada como comunista subversiva.

Su amigo, el juez Robert Ellerbe (Kelly) considera que la bibliotecaria ha sido tratada injustamente, por ello, convoca a la comunidad para intentar ayudarla; sin embargo, el ambicioso candidato político Paul Duncan (Keith), quien tiene una relación sentimental con la bibliotecaria asistente de la Sra. Hull, Martha Lockeridge (Hunter), denuncia a la Sra. Hull como comunista, logrando que el pueblo esté contra ella, excepto Freddie Slater, niño interesado en la lectura y cuyo lugar favorito es la biblioteca. A partir de esto, tanto la vida personal y profesional de Alicia se ennegrecen, como la actitud y comportamiento de Freddie, debido a los comentarios contra la Sra. Hull por parte de su padre y amigos. Los problemas que origina esta situación desembocan en un incendio dentro de la biblioteca, por lo cual, las autoridades le piden a la bibliotecaria reconsiderar la situación y supervisar la reconstrucción de la biblioteca. En este filme, la ética profesional e individual, así como el rol social de la Sra. Hull, están en juego. 


\section{Segmentación y Estratificación}

La segmentación del filme consistió en un recorrido lineal de éste para fragmentarlo en secuencias ${ }^{15}$ y escenas, ${ }^{16}$ como unidades de contenido breves. La división del filme El ojo del huracán exploró la organización y distribución de la trama y el argumento para fragmentar el filme en 25 secuencias, como unidades de contenido, en las que aparece el personaje del bibliotecario y su ambiente.

\section{Segmentación de secuencias del filme}

1. Alicia Hull camina a la biblioteca y platica con los niños.

2. Alicia Hull llega a la biblioteca.

3. Robert le pregunta a su amiga Alicia sobre el libro El Sueno Comunista.

4. Freddie Slater leyendo sobre monstruos en la biblioteca.

5. George Slater dice que su hijo no come porque todo está lleno de palabras.

6. Alicia Hull le pide a George Slater que entienda los gustos de Freddie.

7. Los niños que van a la biblioteca le dicen a Alicia que les compre boletos.

8. Comida con el Consejo Público para hablar sobre la sección de niños.

9. Alicia pregunta ¿Cómo te puedes deshacer de un libro?

10. El libro continúa en la biblioteca.

11. La Junta de la Ciudad, exige a Alicia que saque el libro $U n$ sueño comunista.

15 La secuencia es un conjunto de escenas que mantienen entre sí un vínculo narrativo, que forman parte del desarrollo de una misma idea.

16 La escena es una unidad de acción-situación, que sucede en un mismo espacio y tiempo, y sirve para explicar o modificar algún aspecto de la evolución de personajes y tramas. 
12. Alicia Hull es despedida.

13. Freddie va a visitar a Alicia Hull a su departamento.

14. La comunidad se reúne para discutir el caso de Alicia Hull.

15. George y Laura Slater hablan sobre el comportamiento de Freddie.

16. El pueblo repudia a Alicia Hull en restaurante.

17. Los niños desconocen a Alicia Hull, quien era su consejera y amiga.

18. Martha pregunta a Freddie qué hace en la biblioteca por la noche.

19. Se trata de Freddie, tiene un comportamiento inaudito.

20. Duncan y Martha va a una fiesta con políticos.

21. George Slater le dice a su hijo que Alicia lo ha llenado de ideas comunistas.

22. Robert convence a Alicia Hull de ir a la inauguración de la sala de lectura.

23. Ceremonia de la biblioteca. Freddie está desaparecido.

24. Miembros del Consejo y Robert hablan sobre el comunismo y la biblioteca.

25. Quema de la biblioteca. La comunidad observa.

- Martha termina con Duncan.

- Biblioteca en llamas. Piden a Alicia regresar para la reconstrucción de la biblioteca.

Después de segmentar el filme, se procedió a registrar cada secuencia en la que está presente el personaje del bibliotecario y su ambiente en tanto componente simbólico de la narración, describiendo la acción específica que realiza y el diálogo que sostiene, en un momento determinado y espacio concreto (acervo, sala de lectura, sala de consulta).

Las secuencias se agruparon en cuatro partes representativas de una narración: a) Presentación del personaje b) Problema de la trama, c) Transformación del personaje y d) Solución 
del problema. Estas partes representativas reflejan un personaje que está dentro de una historia, la cual, muestra un problema y, para que continúe el curso de la historia, el protagonista tiene que enfrentar el problema, para o por ello se da una transformación encaminada a la solución de éste.

\section{Mapa de personaje de la bibliotecaria para análisis (ambiente, acción y diálogo)}

\section{Personaje: Alicia Hull}

\begin{tabular}{|c|c|c|c|}
\hline & $\begin{array}{c}\text { Personaje y } \\
\text { Ambiente }\end{array}$ & Acción & Diálogos \\
\hline $\begin{array}{l}\text { Presentación } \\
\text { del } \\
\text { personaje. } \\
\text { La Sra. Hull } \\
\text { llega a la bi- } \\
\text { blioteca. Se- } \\
\text { cuencia } 2 . \\
\text { Tiempo } 1: 48\end{array}$ & $\begin{array}{l}\text { Día, } \\
\text { Interior, } \\
\text { Biblioteca } \\
\text { pública. } \\
\text { Alicia Hull, } \\
\text { Martha y } \\
\text { Carl. }\end{array}$ & $\begin{array}{l}\text { Alicia Hull lle- } \\
\text { ga a la bibliote- } \\
\text { ca, saluda al } \\
\text { personal y ve- } \\
\text { rifica que todo } \\
\text { esté en orden. }\end{array}$ & $\begin{array}{l}\text { Alicia: ¡Buenos días Martha! } \\
\text { ¡Buenos días Carl! ¿Ya terminaste de ordenar las } \\
\text { colecciones? } \\
\text { Carl: En eso estoy, sólo tengo dos manos. } \\
\text { Alicia: Sí, lo sé, cuando requiera algo más con- } \\
\text { trataré más personal. } \\
\text { Martha: Llamaron por el North Wing Book. ¡No } \\
\text { lo han podido localizar! } \\
\text { Alicia: Busquen bajo Arquitectura, en Moder- } \\
\text { nismo: } 724.9 \text {. }\end{array}$ \\
\hline $\begin{array}{l}\text { Problema en } \\
\text { la trama. } \\
\text { Se exige que } \\
\text { saque el libro } \\
\text { Un sueño } \\
\text { comunista. } \\
\text { Secuencia } 11 . \\
\text { Tiempo } \\
\text { 22:08 }\end{array}$ & $\begin{array}{l}\text { Consejo } \\
\text { Público, } \\
\text { Interior, } \\
\text { noche. }\end{array}$ & $\begin{array}{l}\text { Alicia Hull, } \\
\text { Duncan, Ro- } \\
\text { bert, miembros } \\
\text { del Consejo Pú- } \\
\text { blico. } \\
\text { Se exige que } \\
\text { saque el libro. } \\
\text { Un sueño } \\
\text { comunista de } \\
\text { la biblioteca. }\end{array}$ & $\begin{array}{l}\text { Alicia: No puden quitar un libro, solamente por } \\
\text { su contenido } \\
\text { Duncan: Enfoquémonos en el verdadero proble- } \\
\text { ma Sra. Hull. Llegaron una docena de cartas... } \\
\text { ¿Es necesario que este discurso gastado provo- } \\
\text { que tanto alboroto? } \\
\text { Alicia: Me temo que sí. No se puede cambiar a } \\
\text { un bibliotecario ni a un Consejo Público para } \\
\text { agradar a todos [...] } \\
\text { Robert: [...] Quieres convertir la biblioteca en } \\
\text { institución de propaganda a favor del crimen. }\end{array}$ \\
\hline
\end{tabular}




\section{Continuación:}

\begin{tabular}{|c|c|c|c|}
\hline & $\begin{array}{c}\text { Personaje y } \\
\text { Ambiente }\end{array}$ & Acción & Diálogos \\
\hline & & $\begin{array}{l}\text { Asocian el pa- } \\
\text { sado de la Sra. } \\
\text { Hull con el co- } \\
\text { munismo y su } \\
\text { trabajo y repu- } \\
\text { tación está de } \\
\text { por medio. }\end{array}$ & $\begin{array}{l}\text { Alicia: Por favor no me interrumpas. Hay un libro } \\
\text { en la biblioteca que cada vez que lo veía me per- } \\
\text { turbaba. Mi Lucha. La lectura sobre el hitlerismo } \\
\text { pudiera alterar a cualquiera, pero la gente leía este } \\
\text { libro y su reacción era ajena a esta ideología. No } \\
\text { se dan cuenta que al quedarnos con este libro en } \\
\text { la biblioteca atacamos a la corriente comunista. Le } \\
\text { decimos al Comunismo, no tememos lo que tie- } \\
\text { nes que decir. Témenos a nosotros y a la verdad. } \\
\text { [...] Caballeros si quieren que saque este libro de } \\
\text { la biblioteca deberán de luchar para que lo remue- } \\
\text { va del estante. } \\
\text { Alicia: [...] ¿cuál es el motivo de sus preguntas? } \\
\text { ¿a dónde quiere llegar? [...] } \\
\text { Duncan: Era miembro [de asociaciones comunis- } \\
\text { tas] entonces, debe de haber creído en sus ideas. } \\
\text { Alicia: [...] Es obvio que no concordamos en mu- } \\
\text { chas cosas, incluyendo la censura. Si me lo pre- } \\
\text { gunta, no soy una comunista y nunca he sido } \\
\text { comunista [...] } \\
\text { Político: Sólo queremos remover el libro El Sue- } \\
\text { ño Comunista [...] } \\
\text { Alicia: Pensé que al llegar solamente íbamos a } \\
\text { hablar de un libro. Estamos hablando de asuntos } \\
\text { distintos. } \\
\text { [...] } \\
\text { Alicia: Si es la posición en que se encuentran } \\
\text { ustedes y en la que yo estoy, tienen el poder de } \\
\text { remover el libro de la biblioteca y el poder de re- } \\
\text { moverme. Si quieren lo primero tendrán que hacer } \\
\text { lo segundo. }\end{array}$ \\
\hline $\begin{array}{l}\text { Transfor- } \\
\text { mación del } \\
\text { personaje. }\end{array}$ & $\begin{array}{l}\text { Noche, } \\
\text { interior. } \\
\text { Apartamen- } \\
\text { to de Alicia } \\
\text { Hull. }\end{array}$ & $\begin{array}{l}\text { Alicia Hull } \\
\text { y Martha. }\end{array}$ & $\begin{array}{l}\text { Martha: Sí, se trata de Freddie Slater. } \\
\text { El niño tiene un comportamiento inaudito. No } \\
\text { acude mucho a la biblioteca, pero cuando lo hace } \\
\text { su comportamiento es demasiado extraño... } \\
\text { Alicia: Pero ¿por qué viniste a verme? }\end{array}$ \\
\hline
\end{tabular}




\section{Continuación:}

\begin{tabular}{|c|c|c|c|}
\hline & $\begin{array}{c}\text { Personaje y } \\
\text { Ambiente }\end{array}$ & Acción & Diálogos \\
\hline $\begin{array}{l}\text { Se trata de } \\
\text { Freddie, tiene } \\
\text { un compor- } \\
\text { tamiento } \\
\text { inaudito } \\
\text { Secuencia } 19 . \\
\text { Tiempo } \\
\text { 50:58 }\end{array}$ & & & $\begin{array}{l}\text { Martha: Ud. tiene mucha influencia en él y sabe } \\
\text { cómo manejarlo. } \\
\text { Alicia: Ya no más. Hace mucho que no lo veo. } \\
\text { [...] Ya no hago muchas cosas que solía hacer, y } \\
\text { no por elección. Por lo cual, debería agradecerles } \\
\text { a ti y al Sr. Duncan. } \\
\text { Martha: Discúlpeme por los problemas. Nos cul- } \\
\text { pa a mí y al Sr. Duncan ¿no es así? } \\
\text { Alicia: Culparlos ¿por qué? Porque he dejado de } \\
\text { tener mi vida. } \\
\text { Martha: Pero mi intención era... } \\
\text { Alicia: Por favor no digas que lo lamentas. } \\
\text { Martha: Pero Sra. Hull solamente fue un miem- } \\
\text { bro del Consejo y no lo hizo para causarle daño. } \\
\text { Se sentiría mejor si lo pudiera creer. } \\
\text { Alicia: Martha, he intentado mantenerme a la al- } \\
\text { tura estos últimos meses. Entender a las personas } \\
\text { y mantenerme ocupada. Pero podrás entender que } \\
\text { no me interesa si tú o Duncan buscan sentirse } \\
\text { mejor. }\end{array}$ \\
\hline $\begin{array}{l}\text { Solución del } \\
\text { problema } \\
\text { "Quema de la } \\
\text { biblioteca" } \\
\text { Secuencia } 25 \\
\text { i. Martha } \\
\text { termina con } \\
\text { Duncan. }\end{array}$ & $\begin{array}{l}\text { Interior / } \\
\text { Exterior, } \\
\text { Quema de } \\
\text { la biblio- } \\
\text { teca, noche. }\end{array}$ & $\begin{array}{l}\text { Alicia Hull, } \\
\text { Martha y } \\
\text { Duncan. }\end{array}$ & $\begin{array}{l}\text { Martha: Vamos, repítemelo. Este acto tan atroz } \\
\text { no sucedió, sólo un pequeño niño se volvió } \\
\text { lunático. La gente buena, normal no inició el } \\
\text { fuego, fueron los lunáticos. } \\
\text { Duncan: Martha, nos vendría bien una copa. } \\
\text { Vamos a mi casa. } \\
\text { Martha: No lo entiendes aún, ¿verdad? Ya no } \\
\text { quiero nada más. No quiero estar relacionada } \\
\text { con un joven político en ascenso, preferiría estar } \\
\text { sola. [...] } \\
\text { Ciudadano: Sra. Hull, ya sabe del muchacho. } \\
\text { No fue solamente el niño, la culpa la tenemos } \\
\text { todos. } \\
\text { Martha: La culpa también es mía, no quise } \\
\text { oponerme. }\end{array}$ \\
\hline
\end{tabular}


Continuación:

\begin{tabular}{|l|l|l|l|}
\hline & $\begin{array}{c}\text { Personaje y } \\
\text { Ambiente }\end{array}$ & Acción & \multicolumn{1}{c|}{ Diálogos } \\
\hline $\begin{array}{l}\text { ii Biblioteca } \\
\text { en llamas. }\end{array}$ & & $\begin{array}{l}\text { Director: Escuché que va a viajar, espero que } \\
\text { cambie de opinión. Debe ayudarnos a recon- } \\
\text { struir la biblioteca, no se vaya. } \\
\text { Tiempo } \\
78: 36\end{array}$ & $\begin{array}{l}\text { Alicia: No pienso irme, me quedaré y los } \\
\text { ayudaré a reconstruir esta biblioteca. Si alguien } \\
\text { intenta, nuevamente sacar un libro, tendrá que } \\
\text { hacerlo sobre mi cadáver. }\end{array}$ \\
\hline
\end{tabular}

\section{Sistematización}

El proceso de sistematización abarca la enumeración y reagrupamiento de elementos para el análisis. La del texto inicia con un registro de elementos simbólicos presentes en la dimensión psicológica y social del personaje del bibliotecario y su ambiente específico de la biblioteca.

\section{Mapa de elementos simbólicos de la narración: Dimensión psicológica y social}

\begin{tabular}{|l|l|l|l|}
\hline Secuencia & Dimensión psicológica & Dimensión social & Emoción \\
\hline $\begin{array}{l}\text { Alicia Hull } \\
\text { llega a la } \\
\text { biblioteca. } \\
\text { Secuencia 2. } \\
\text { Tiempo: 1: } 48\end{array}$ & $\begin{array}{l}\text { Personalidad. } \\
\text { Estabilidad emocional: } \\
\text { Tranquila, segura. }\end{array}$ & $\begin{array}{l}\text { Interacción social: } \\
\text { Reservada, asertiva, confiada. } \\
\text { Amabilidad: realista, } \\
\text { Nacionalidad: } \\
\text { estadounidense } \\
\text { Educación: Bibliotecología } \\
\text { Profesión: Directora de la } \\
\text { biblioteca pública. } \\
\text { Rol del personaje. } \\
\text { Relevancia: Protagonista } \\
\text { Focalización: Centro de } \\
\text { equilibrio. }\end{array}$ & Alegría \\
& & $\begin{array}{l} \\
\end{array}$ & \\
\hline
\end{tabular}




\section{Continuación:}

\begin{tabular}{|c|c|c|c|}
\hline Secuencia & Dimensión psicológica & Dimensión social & Emoción \\
\hline & & $\begin{array}{l}\text { Clase de acciones } \\
\text { del personaje: } \\
\text { Personaje activo, influyente. } \\
\text { Actividades profesionales } \\
\text { reflejadas: Dirección y } \\
\text { organización de la biblioteca, } \\
\text { Conoce las colecciones de la } \\
\text { biblioteca. }\end{array}$ & \\
\hline $\begin{array}{l}\text { Se exige que } \\
\text { saque el libro } \\
\text { Un sueño } \\
\text { comunista. } \\
\text { Secuencia } \\
\text { 11. Tiempo: } \\
\text { 22:08 }\end{array}$ & $\begin{array}{l}\text { Personalidad. } \\
\text { Estabilidad emocional: } \\
\text { segura, } \\
\text { satisfecha. } \\
\text { Interacción social: } \\
\text { abierta, activa. } \\
\text { Apertura: tolerante. } \\
\text { Amabilidad: realista, } \\
\text { desconfiada. } \\
\text { Responsabilidad: } \\
\text { organizada, cuidadosa. }\end{array}$ & $\begin{array}{l}\text { Rol del personaje. } \\
\text { Relevancia: peso que asume } \\
\text { en los acontecimientos. } \\
\text { Focalización: foco de } \\
\text { atención. } \\
\text { Clase de acciones } \\
\text { del personaje: } \\
\text { Personaje activo, } \\
\text { autónomo, antagonista. }\end{array}$ & $\begin{array}{l}\text { Cólera } \\
\text { sorpresa }\end{array}$ \\
\hline $\begin{array}{l}\text { Freddie tiene } \\
\text { un comporta } \\
\text { miento } \\
\text { inaudito } \\
\text { Secuencia } \\
\text { 19. Tiempo: } \\
\text { 50:58 }\end{array}$ & $\begin{array}{l}\text { Personalidad. } \\
\text { Estabilidad emocional: } \\
\text { insegura. } \\
\text { Interacción social: reservada, } \\
\text { pasiva. } \\
\text { Apertura: intolerante } \\
\text { Amabilidad: realista, } \\
\text { desconfiada. }\end{array}$ & $\begin{array}{l}\text { Rol del personaje. } \\
\text { Relevancia: peso que asume } \\
\text { en la transformación del } \\
\text { personaje. } \\
\text { Focalización: foco de atención. } \\
\text { Clase de acciones } \\
\text { del personaje: } \\
\text { pasiva, conservadora. }\end{array}$ & Tristeza \\
\hline $\begin{array}{l}\text { Quema de la } \\
\text { biblioteca. } \\
\text { Secuencia } \\
\text { 25. Tiempo: } \\
\text { 78:36 }\end{array}$ & $\begin{array}{l}\text { Personalidad. } \\
\text { Estabilidad emocional: } \\
\text { segura. } \\
\text { Interacción social: solemne. } \\
\text { Amabilidad: realista, } \\
\text { cooperadora. } \\
\text { Responsabilidad: responsable. }\end{array}$ & $\begin{array}{l}\text { Rol del personaje. } \\
\text { Relevancia: peso que asume } \\
\text { en los acontecimientos, } \\
\text { centro de equilibrio. } \\
\text { Clase de acciones: personaje } \\
\text { activo, influyente, modificador. } \\
\text { Actividades profesionales } \\
\text { reflejadas: Dirección. }\end{array}$ & Disgusto \\
\hline
\end{tabular}


En la dimensión psicológica, los rasgos de personalidad caracterizados por el personaje del bibliotecario en la narración y discurso cinematográfico en cada filme se agrupan en cinco categorías: estabilidad emocional, apertura, amabilidad, responsabilidad e interacción social.

\begin{tabular}{|l|l|l|l|l|l|}
\hline $\begin{array}{l}\text { Título y } \\
\text { secuencia }\end{array}$ & $\begin{array}{l}\text { Estabilidad } \\
\text { emocional }\end{array}$ & $\begin{array}{c}\text { Interacción } \\
\text { social }\end{array}$ & Apertura & Amabilidad & Responsabilidad \\
\hline $\begin{array}{l}\text { Alicia Hull } \\
\text { llega a la } \\
\text { biblioteca. } \\
\text { (2) }\end{array}$ & $\begin{array}{l}\text { tranquila, } \\
\text { segura }\end{array}$ & $\begin{array}{l}\text { activa, } \\
\text { controlada }\end{array}$ & cooperadora & $\begin{array}{l}\text { organizada, } \\
\text { responsable }\end{array}$ \\
\hline $\begin{array}{l}\text { Se exige } \\
\text { que saque } \\
\text { el libro } \\
\text { Un sueño } \\
\text { comunista. } \\
\text { (11) }\end{array}$ & segura & $\begin{array}{l}\text { abierta, } \\
\text { activa }\end{array}$ & liberal & desconfiada & responsable \\
\hline $\begin{array}{l}\text { Freddie } \\
\text { tiene } \\
\text { compor- } \\
\text { tamiento } \\
\text { imposible. } \\
\text { (19) }\end{array}$ & sensible & $\begin{array}{l}\text { reservada, } \\
\text { pasiva }\end{array}$ & intolerante & desconfiada & inconstante \\
\hline $\begin{array}{l}\text { Quema de } \\
\text { la biblio- } \\
\text { teca. (25) }\end{array}$ & segura & $\begin{array}{l}\text { solemne, } \\
\text { reservado }\end{array}$ & tolerante & $\begin{array}{l}\text { realista, } \\
\text { desconfiada }\end{array}$ & responsable \\
\hline
\end{tabular}

En la dimensión social se identifican las siguientes categorías: características socio-demográficas, actividades y funciones profesionales que se reflejan en los filmes. No obstante, la reagrupación social del personaje del bibliotecario se enfocó en las siguientes categorías: el rol narrativo del personaje 
(relevancia y focalización del bibliotecario), el análisis de la clase de acciones y actividades profesionales que desempeña en la trama.

\begin{tabular}{|l|l|l|l|}
\hline \multicolumn{1}{|c|}{$\begin{array}{c}\text { Características } \\
\text { sociales }\end{array}$} & $\begin{array}{c}\text { Rol del } \\
\text { personaje }\end{array}$ & Clase de acciones & $\begin{array}{c}\text { Actividades } \\
\text { profesionales en filme }\end{array}$ \\
\hline $\begin{array}{l}\text { Viuda, estadounidense, } \\
\text { clase media alta } \\
\text { estudios biblio- } \\
\text { tecología, directora } \\
\text { biblioteca. }\end{array}$ & Protagonista & Activo, influyente & $\begin{array}{l}\text { Organización } \\
\text { de la biblioteca. } \\
\text { Proporcionar } \\
\text { información. } \\
\text { Servicio de circulación. }\end{array}$ \\
\hline
\end{tabular}

\section{DISCUSIÓN}

Como resultado de este análisis podemos responder a las preguntas sobre lo que se puede ver y leer en el filme $E l$ ojo del buracán.

En la Dimensión Psicológica del personaje ¿qué vemos en el estereotipo? En el film, la bibliotecaria Alicia Hull es una mujer adulta, rígida, inflexible y restrictiva, que es lo que generalmente se aprecia.

En la Dimensión Psicológica del personaje ¿qué leemos en el discurso cinematográfico? En El ojo del huracán, los atributos positivos de la caracterización del personaje pueden leerse a través de la bibliotecaria Alicia Hull, quien proyecta una personalidad segura, abierta, confiada, responsable, controlada, cooperadora y realista, en vez de una personalidad tímida, introvertida o pasiva, que es considerada como estereotipo del bibliotecario. Estos rasgos se pueden leer en diferentes segmentos.

En la secuencia dos (Alicia llega a la biblioteca) se muestra segura, tranquila y ordenada. En la secuencia 11 (Se exige que 
retire el libro Un sueño comunista) abierta, tolerante, realista y responsable, lo que se percibe cuando dice "Si es la posición en que se encuentran ustedes y en la que yo estoy, tienen el poder de remover el libro de la biblioteca y el poder de removerme. Si quieren lo primero tendrán que hacer lo segundo”.

En la secuencia 19 (Freddie tiene comportamiento inaudito) se expone reservada, pasiva, realista y desconfiada; lo demuestra cuando le responde a Martha: "He intentado mantenerme a la altura estos últimos meses. Entender a las personas y mantenerme ocupada, pero podrás entender que no me interesa si tú o el Sr. Duncan buscan sentirse mejor". Esto se debe a que por no retirar el libro de la biblioteca, fue despedida y excluida por la comunidad que la dejó sola, triste, abandonada y desmoralizada. ${ }^{17}$

En la secuencia 25 (Quema de la biblioteca) se muestra segura, seria, y controlada, cooperadora cuando dice: "No pienso irme, me quedaré y los ayudaré a reconstruir esta biblioteca. Si alguien intenta, nuevamente sacar un libro, tendrá que hacerlo sobre mi cadáver". En esta escena regresa más fuerte y decidida a cumplir con la misión de la biblioteca: facilitar a los usuarios el acceso a la información.

En cuanto a los atributos negativos asignados a las bibliotecarias en el filme El ojo del huracán, en la Sra. Hull, se observan rasgos de personalidad pasiva cuando acepta inicialmente retirar el libro de la biblioteca. Tevis ${ }^{18}$ señala que la Sra. Hull y Martha son pasivas porque permiten que las controlen, aunque al final de la película, cada una de ellas manifiesta coraje y valor para defender sus convicciones, por un lado, Alicia Hull en cuanto a su rol frente a la biblioteca y, por otro, Martha en

17 Raish Martin, "Librarians in the movies: an annotated filmography".

18 Ray Tevis and Brenda Tevis, The Image of Librarians in Cinema, 1917-1999, pp. 85-86. 
torno a su relación con el político Duncan. También se observa que Alicia se muestra pasiva, desconfiada y reservada después de haber sido despedida y esos rasgos son congruentes con la circunstancia.

En la Dimensión Social del personaje ¿qué vemos en el estereotipo? En El ojo del Huracán, se observa principalmente en el estereotipo del personaje: Alicia Hull es una bibliotecaria mujer, vive sola, soltera o viuda. Las tareas que realiza son expresamente operativas, tales como búsqueda, localización, préstamo y ordenamiento de los libros.

En la Dimensión Social del personaje ¿qué leemos en el discurso cinematográfico? En la lectura interpretativa del discurso cinematográfico del filme El ojo del buracán, la bibliotecaria sigue sus convicciones en cuanto a la libertad intelectual y la censura, negándose a retirar el libro (El sueño comunista) de la biblioteca, aún cuando arriesga su trabajo y es despedida, protege el derecho de los usuarios a leer lo que quieran, que actualmente está establecido como derecho de acceso a la información.

En el caso Storm Center, filmada en 1956, la trama hace referencia a la censura, ella demostró seguridad, responsabilidad y carácter firme, argumentando su posición ante el Comité (dimensión psicológica). Defendió los derechos civiles y el acceso a la información, siguiendo su convicción respecto a la libertad intelectual y la censura (dimensión social), aún con el riesgo de perder su empleo y ser juzgada por la comunidad. Generalmente, estas últimas dos dimensiones no se leen ni se analizan porque las características físicas siguen teniendo mayor peso visual, tampoco se profundiza el contexto que representa.

Por lo tanto, la lectura de este filme no puede limitarse en abordar el estereotipo sobre la apariencia física y destacar solo a la adulta, robusta; con trajes conservadores, oscuros, usando anteojos y de personalidad gris; ya que como lo afirmó la 
American Library Association, se trató de una obra cinematográfica de la que "todos los bibliotecarios puedan estar orgullosos". ${ }^{19}$ Es de subrayar, que este filme llevó a la pantalla un acontecimiento de la vida real situado en el ámbito bibliotecológico, donde el choque ideológico comunista estaba latente.

Ahora bien, en cuanto a las intersecciones de la información, la imagen y el conocimiento, en este trabajo, se demuestra que la lectura metodológica del discurso cinematográfico, enfocada en las imágenes cinematográficas del personaje del bibliotecario, produce nueva información derivada de la lectura y el análisis de las imágenes específicas, y del filme en general. Esta

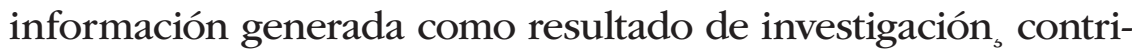
buye a construir un nuevo conocimiento sobre la representación psicológica y social del bibliotecario en los filmes.

\section{CONCLUSIONES}

- El personaje del bibliotecario en el cine comparte características psicológicas y sociales, pero generalmente éstas no se leen ni se analizan porque los atributos físicos -reiterados constantemente como negativos-conforman el núcleo de los estereotipos que se ha anclado en el imaginario social y, en consecuencia, han impactado en su imagen, estatus profesional y reconocimiento social.

- Los estudios sobre el personaje del bibliotecario en el cine, en su mayoría, son de carácter descriptivo y se concentran principalmente en atributos físicos negativos, en ciertos rasgos de personalidad -introvertido, tímido, pasivo- y sólo en algunas tareas operativas, debido a que son los elementos más visuales, pero sin profundizar en un aná-

19 American Library Association, "Storm Center", pp. 426-427. 
lisis estructurado y en la interpretación de todos los razgos que conforman las dimensiones psicológicas y sociales.

- Esta metodología de lectura sobre el discurso cinematográfico favorece el análisis estructurado de las dimensiones psicológica (rasgos de personalidad y emociones) y social (actividades profesionales y roles) del personaje del bibliotecario, proporcionando un valor agregado en la interpretación de su representación social.

- A modo de epílogo, sugiero que se debe considerar el estudio de la obra cinematográfica en el campo bibliotecológico y, en particular, su lectura; lo cual, es objeto de futuras investigaciones.

\section{BIBLIOGRAFÍA}

Acaso, María, El lenguaje visual, Barcelona, Paidós, 2011.

American Library Association, "Censorship in Bartlesville". ALA Bulletin 45, no. 3, 1951, pp. 87-90.

- - -, "Storm Center", ALA Bulletin 50, no. 7, 1956, pp. 426-427.

Barthes, Roland, El susurro del lenguaje. Más allá de la palabra y de la escritura, Barcelona, Paidós, 1987.

Cassetti, Francesco y Federico Di Chio, Cómo analizar un film, Barcelona, Paidós, 1991.

Iturbe Fuentes, Luis Raúl, Indización de la cinematografía basada en la intertextualidad, Tesis de licenciatura en Bibliotecología, UNAM, Filosofía y Letras, Colegio de Bibliotecología, 2009.

Iturbe Fuentes, Luis Raúl, Las representaciones del bibliotecario en el discurso cinematográfico, Tesis de maestría en bibliotecología, UNAM, Posgrado de Bibliotecología, 2013. 
Marcel, Martin, El lenguaje del cine, Barcelona, Gedisa, 2005.

Martin, Raish, "Librarians in the movies: an annotated filmography”, Brigham Young, University Idaho. http://emp.byui. edu/raishm/films/introduction.html

Taradash, Daniel, (dir.) El ojo del huracán [película], Estados Unidos, Julian Blaustein Productions, 1956.

Tevis, Ray y Brenda Tevis, The Image of Librarians in Cinema, 1917-1999, United States, McFarland \& Company, Inc., Publisher, 2005.

Zavala, Lauro, Elementos del discurso cinematográfico, Universidad Autónoma Metropolitana Xochimilco, Colección Libros de Texto, 2003.

Zunzunegui, Santos, Pensar la imagen, Madrid, Universidad del País Vasco, 2007. 


\title{
¿Dónde y cómo morirán los libros? la obra Réquiem
}

\author{
EMILIO CHAPELA ${ }^{1}$
}

Fondo Nacional para la Cultura y las Artes



1 FONCACEmilio Chapela para todas las imágenes. 


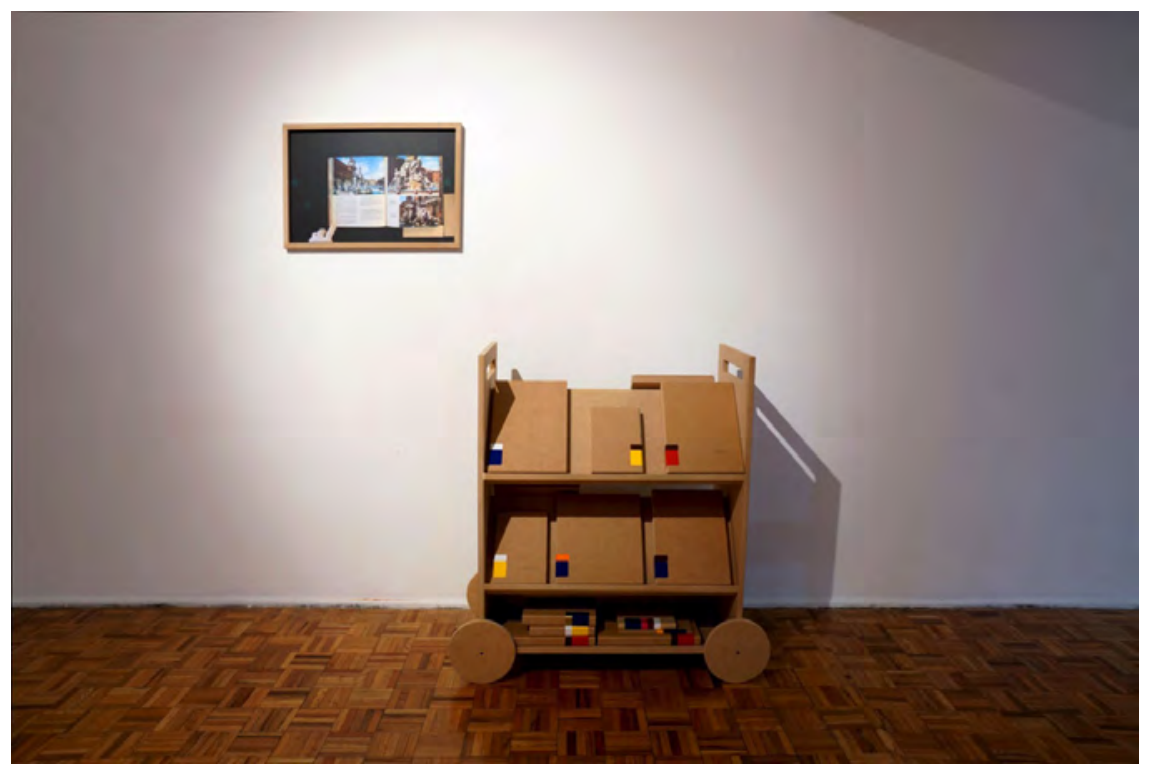

Réquiem es una "réplica" de la Biblioteca personal de David Alfaro Siqueiros: una copia exacta y a escala real de cada uno de sus libros que constituyen una nueva biblioteca de libros carrocería, de cuerpos inertes hechos de madera que no pueden ser leídos. La "copia" consta de más de 2,500 bloques de madera comprimida (MDF) dispuestos en el espacio de galería en libreros que sugieren un espacio de biblioteca, un centro de documentación inaccesible, truncado; con libros que no pueden leerse; con mesas y sillas que no se pueden usar. 


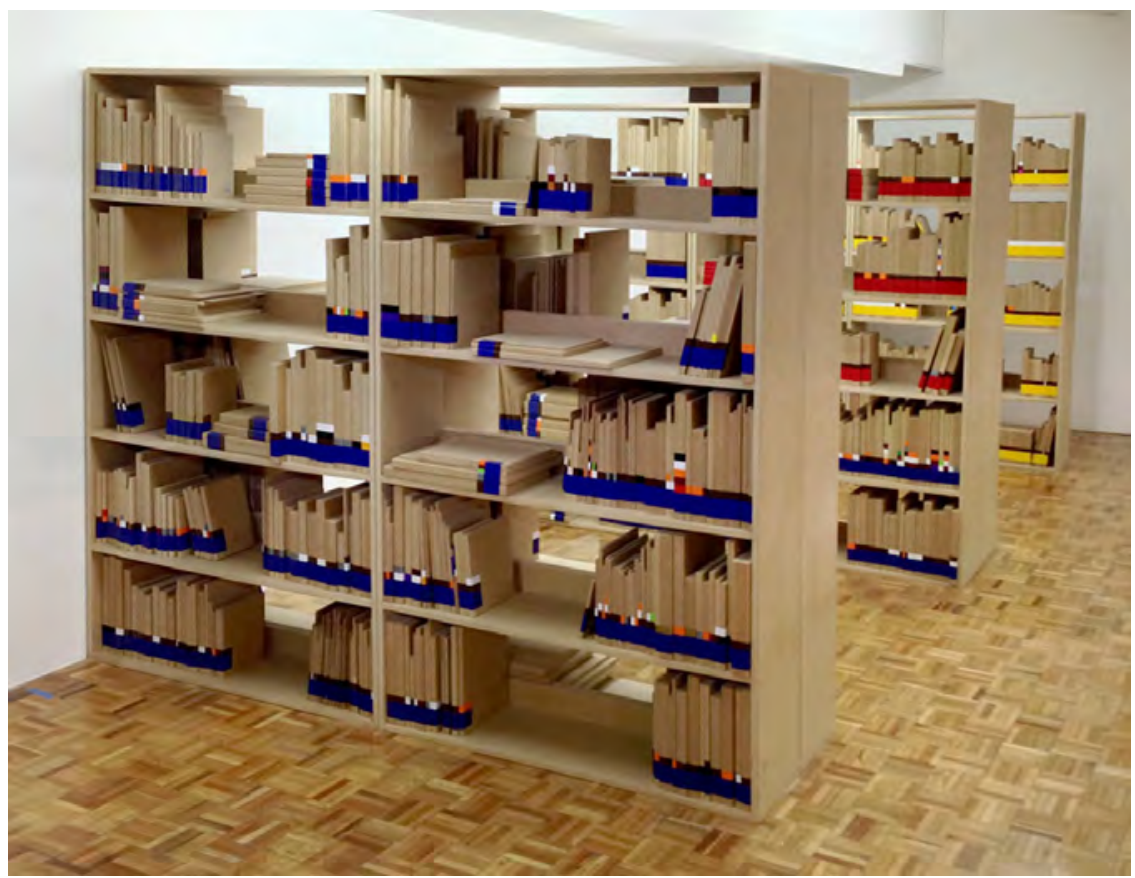

La "réplica" mantiene la misma clasificación que la biblioteca original, dividida en tres grandes grupos (Arte, Politica y Varios) y sugiere un nuevo nivel de clasificación basado en los idiomas de cada uno de los libros (español, francés, inglés, ruso, alemán, náhuatl, chino y japonés, entre muchos otros). Dichas estructura y sub-estructuras de clasificación son visibles a través de etiquetas de color que permiten al espectador reorganizar la biblioteca bajo distintos criterios a través de sus colores. 


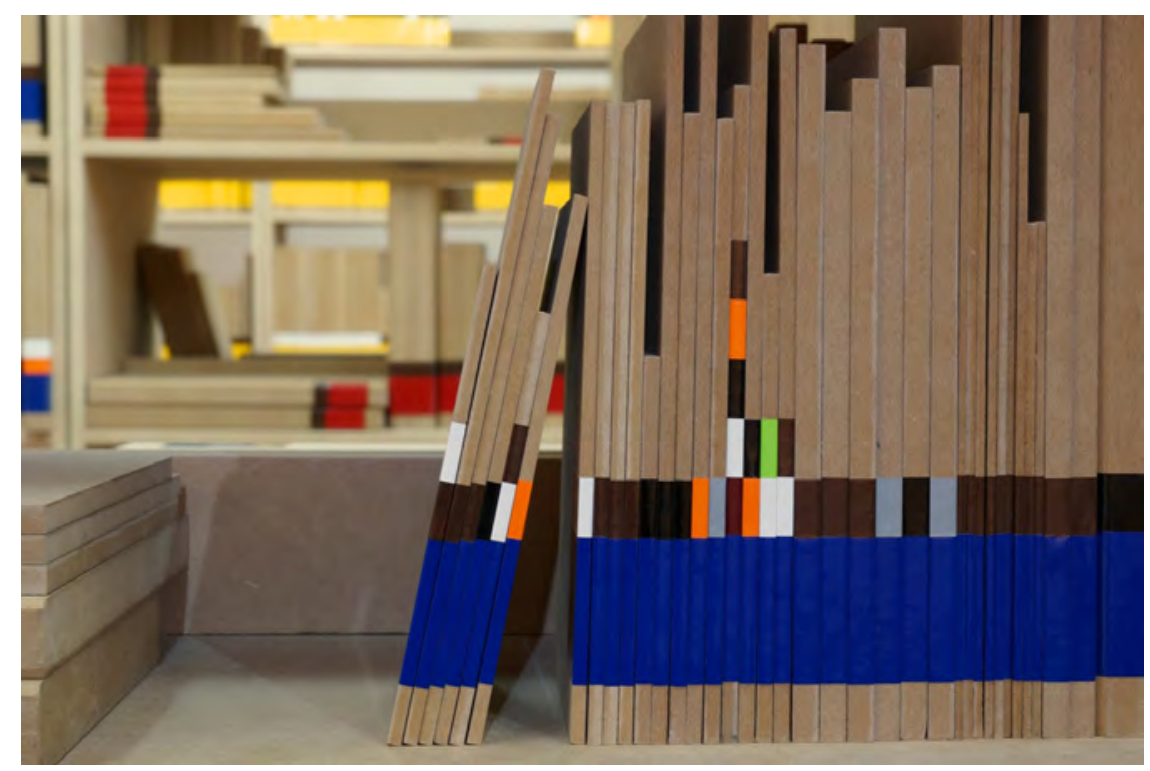

La biblioteca personal de Siqueiros se está digitalizando con el objetivo de que en el futuro cercano, sus títulos estén disponibles para todos en Internet, pero la digitalización no es trivial y tiene consecuencias importantes: la mudanza del libro al mundo digital puede significar la muerte de su cuerpo y, sólo en algunos casos, el renacer del texto.

El proyecto aborda esta problemática. Es un estudio estructural que pone de manifiesto el esqueleto temático de la Biblioteca de Siqueiros y, al mismo tiempo, se pregunta por el futuro de los libros en medio de la revolución digital.

Alrededor de la biblioteca cuelgan 12 imágenes que corresponden a una selección de errores de escaneo que surgieron durante el proceso de digitalización de la Biblioteca. No son ni libros (visto como objeto), ni tampoco son texto; son una falla, un problema en la traducción del mundo análogo al digital. 
Finalmente, la muestra contiene un video sobre el acto mismo de digitalización: el momento exacto cuando la luz transfiere las palabras impresas en información binaria. El momento en que la vida del objeto termina metafóricamente y donde el texto se libera potencialmente. El video es un Réquiem y una reinvención al mismo tiempo. Esta situación describe con mucha justicia la situación actual del libro y las bibliotecas.

\section{Alma Y CUERPO}



Opongo resistencia a utilizar la metáfora que evoca al cuerpo-alma para hacer un análisis actual del libro, pero me funciona. Por lo que para los alcances de esta ponencia, reconoceré temporalmente dos entidades fundamentales del hombre: alma y cuerpo.

Tanto los detractores del ebook como los amantes de los libros tradicionales, construyen, con frecuencia, su apología del 
libro impreso desde el terreno de lo sentimental y lo sensorial: evocan el olor de las páginas, su color amarillento y su calidez al tacto; hablan también del diseño de la portada, de la tinta y calidad de impresión. Dichas cualidades resultan disfrutables para muchos, pero son subjetivas y dependen de las preferencias personales. Por otro lado, la defensa al libro desde su estructura misma, es menos frecuente y no necesariamente interesante. Me refiero, por ejemplo, a la posibilidad que nos da el libro de hacerle anotaciones, su linealidad, el índice, el separador, etc.

Es importante reconocer que todas éstas características son identificables con las propiedades materiales del libro. Es decir, son propiedades que corresponden con su cuerpo. Los libros de papel tienen volumen, textura, peso, tamaño, etc. Sin miedo de reconocer lo obvio, tienen estas características porque existen en el mundo de lo físico. El texto - no la tinta impresa- pertenece al mundo de lo inmaterial y permanece latente hasta que es leído. Por conveniencia de mis argumentos -y por honrar a la metáfora- es justo decir que lo que está escrito en un libro, es su alma. Mientras que el libro, visto como objeto, corresponde al cuerpo. El texto pertenece al mundo del lector, no al de los objetos. Mientras el objeto corresponde en el librero.

Entendido esto y dando un brinco aventurado -quizás cuántico- creo que el aura del libro está conectada estrechamente con su cuerpo y no con su alma. Y que por lo tanto, el aura se desvanece con la digitalización. De modo que el escáner se convierte es un devastador de auras.

Walter Benjamin habla del desvanecimiento del aura como resultado de la reproducción mecánica: A mayor democratización, menor aura. ${ }^{1}$ Por lo que es consecuente pensar que los

1 W. Benjamin, La obra de arte en la época de su reproductibilidad técnica, México, Itaca, 2011. 
libros que se publican hoy en día -y desde que se inventó la imprenta- tienen el aura mermada. En sentido opuesto y como la intuición lo sugiere, el paso del tiempo amplifica el aura (del original), de tal modo que los libros revalúan su aura con el paso del tiempo. Los coleccionistas y vendedores de libros viejos y primeras ediciones entienden muy bien esto. Su negocio consiste en acercarnos al rito original de la escritura. Entre más viejo el libro, más cerca de su autor.

En el mundo digital, en cambio, se habla de actualizaciones, donde lo importante es tener la última versión posible, la más actualizada y la "mejor". En contraste con los libros de papel, la versión más antigua no es la más codiciada, sino la obsoleta. Los libros digitales no envejecen: se actualizan y se sustituyen, pero no se degradan.

\section{CONCLUSIÓN}

La exposición Réquiem no busca anunciar la muerte del libro impreso, ni rescatarlo del olvido. Tampoco promociona, defiende o plantea una apología al mundo digital. Es más bien, un pretexto para discutir y plantear preguntas: ¿Serán las Bibliotecas el lugar donde los libros morirán? ¿Cómo serán los espacios de Bibliotecas del futuro? ¿Qué consecuencias trae consigo el proceso de digitalización?

Réquiem es también un intento -quizá inútil- de probar que el desvanecimiento del aura de Benjamin no se extiende a la realidad actual. Y de probar que hay un espacio -aparentemente inerte e inaccesible- entre el papel y el mundo digital, donde puede existir una revaloración del aura. 
El peregrinaje textual de la imagen: la intermediación del lenguaje documental y las distorsiones cognitivas

\author{
CATAlina PÉREZ MElÉNDEZ \\ Dirección General de Bibliotecas de la UNAM
}

PARTE I

Toda lectura implica una colaboración $y$ casi una complicidad.

J.L.Borges

La tarea que intento llevar a cabo, gracias al poder de la palabra escrita es haceros oír, haceros sentir.., es, antes que nada, haceros ver.

Conrad

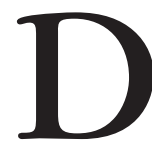
esde 1934 Paul Otlet precisó que la disciplina -denominada por él, en aquella época, como bibliologíarequería de "una teoría de la transmisión de conocimientos por medio de imágenes [...] cada vez más multiplicadas y propagadas al máximo". ${ }^{1}$ A lo largo de su obra Traité de documentation presentó algunas ideas que instaban la validación

1 Paul Otlet, El tratado de documentación: el libro sobre el libro: teoría y práctica, p. 77. 
de diversos tipos de imágenes como documentos, ${ }^{2}$ y con ello, establecía para el futuro de la disciplina bibliotecológica la relevancia del estudio y tratamiento documental de las imágenes. Sin el eco del aporte de Otlet, las manifestaciones visuales han figurado marginalmente en las bibliotecas, bajo un papel secundario que se aboca a la auxiliariedad y fungir como complemento de la información escrita.

El interés de este trabajo es compartir algunas reflexiones en torno a la dimensión documental de las imágenes con respecto a las prácticas bibliotecarias contemporáneas relativas al análisis documental, sin abordar aspectos relativos a la descripción física de los dispositivos pertenecientes a las imágenes.

Desde el Seminario Pensamiento Teórico Bibliotecológico del IIBI, partimos de un diagrama conceptual propuesto por el Dr. Alfaro para señalar que la lectura de la imagen se encuentra en una fase como 'objeto límite de conocimiento' en Bibliotecología, es decir, que no se ha enfrentado tal objeto de estudio. Enlazado a este condicionamiento retomo el concepto de 'distorsión cognitiva' -que forma parte del diagrama- para indicar que las distorsiones se manifiestan como la dificultad al describir objetos e imágenes de la esfera de la cultura visual en el quehacer cotidiano de la catalogación.

La distorsión cognitiva se irradia en varias fases de dicha práctica. Se observa en la configuración de la imagen bajo el esquema de registro textual y términos en cómo se organiza éste. El telón de fondo de esta configuración es el pensamiento polarizado respecto a la manera de considerar las imágenes bajo una oposición binaria frente el texto. Como lo señala Mitchell, ${ }^{3}$ la oposición binaria es un argumento que se basa en una supuesta primacía y triunfo de modelos textuales por encima

$2 \quad$ Ibid., p. 193.

3 William T. J. Mitchell, Teoría de la imagen. 
de componentes visuales, y con el cual, el texto se valora como canal válido para la difusión del conocimiento. Aunado a esta observación, vislumbramos también la influencia del determinismo lingüístico, herencia de nuestra cultura escrita ennoblecida con el proyecto de la Ilustración y validada históricamente desde los agentes institucionales hasta la práctica cotidiana.

Si se contrasta la idea absoluta de oposición binaria texto/ imagen con la realidad fáctica contenida en un libro, es incongruente sostenerla, dado que es difícil no reconocer que la creación de una obra mediada no sólo se expresa a través de la palabra escrita. Con el incremento de los recursos de naturaleza convergente se manifiesta la fracturación gradual de esta oposición. Es cuestión de repasar parte de la historia editorial para encontrar una variedad de ejemplos.

A fin de muestra, cabe mencionar al Atalanta fugiens, ${ }^{4} \mathrm{pu}-$ blicado en 1617 , libro en el que se percibe una visión multimedial precursora debido a que el autor creó su obra a partir de la conjunción de grabados de emblemas, epígrafes, texto y partituras de 50 piezas musicales. Asimismo, otra obra contemporánea, El primer y nveva corónica $i$ bven gobierno, ${ }^{5}$ es reconocida actualmente como objeto de investigación literaria y artística que consigue borrar las distinciones entre texto e imagen. ${ }^{6}$ Si se indagan ejemplos más cercanos recordemos Twentysix Gasoline Stations, ${ }^{7}$ el libro de artista del que destaca la anécdota de haber sido inicialmente rechazado por la Biblioteca del Congreso de E.U., por su forma no ortodoxa y supuesta carencia

\footnotetext{
$4 \quad$ Michel Maier, Atalanta fugiens.

5 Felipe Guaman Poma de Ayala, El primer y nveva corónica $i$ bven gobierno.

6 Rolena Adorno, Guaman Poma y su crónica ilustrada del Perú colonial: un siglo de investigaciones hacia una nueva era de lectura.

7 Edward Ruscha, Twentysix Gasoline Stations.
} 
de información. ${ }^{8}$ La obra referida se compone de fotografías en blanco y negro, sin ningún texto ni siquiera para intitular las imágenes. A pesar del inicial rechazo, este libro contó con gran difusión gracias a la valoración determinante que promovió Clive Phillipot, ${ }^{9}$ al ser director de la biblioteca del MoMA de Nueva York, hacia 1977.

Y si trasladamos el mismo cuestionamiento, que se observa desde la cultura escrita al ámbito digital, no cabe duda que se exacerba la transformación y acelera la ruptura con el paradigma de oposición binaria texto/imagen. Mientras que la vida moderna exista en y desde la pantalla, sean múltiples y distintas pantallas, como lo expresa Mirzoeff, ${ }^{10}$ el espacio digital será la panacea del crecimiento exponencial de la creación multimedial de los 'objetos' mixtos.

Desde la bibliotecología el acercamiento hacia las imágenes está mediado por el lenguaje escrito y, como sujetos partícipes de la disciplina, no somos los únicos que requerimos de éste, en los estudios de arte pervive el acercamiento descriptivo, discursivo e interpretante del lenguaje.

Flor postula una imagen de las disciplinas humanistas más radical, en la que señala que existe una "categoría de especialistas entrenados como depositarios de un capital de letra escrita cuyo acceso regulan según muy secretos y complejos protocolos, logrando por esta vía, y hasta hoy, acceder a una posición de poder mediante el control selectivo del saber", ${ }^{11}$ argumenta que dicha condición influye en la limitación del conocimiento de la cultura visual.

8 Edward Ruscha, Edward Ruscha Editions, p. 60.

9 Para conocer los antecedentes de la valoración de libros de artista, cfr. Clive Phillipot, Booktrek: selected essays on artists' books since 1972.

10 Nicholas Mirzoeff, Una introducción a la cultura visual.

11 Fernando R. de la Flor, Giro visual: primacía de la imagen y declive de la lecto-escritura en la cultura postmoderna, p. 17. 
La intermediación textual en sí misma no es un inconveniente, dado que, hasta ahora, es la forma más factible para representar a la imagen cuando no está presente.

El lenguaje documental es un lenguaje artificial que funciona como herramienta para determinar los puntos de acceso a un recurso. En la práctica nacional se han preferido los lenguajes documentales que instan por el control y coordinación de la representación como norma. De esta manera, la actividad de análisis documental se ve provista de medios homogéneos de recuperación. No obstante, los problemas emergen cuando la noción de representar lo visual mediante la intermediación textual se desvirtúa y genera distorsiones cognitivas.

En dos contextos principales de práctica se revela la distorsión cognitiva. Uno resulta de la inexistencia del análisis documental en las colecciones especiales y, el otro, se genera al realizar la descripción temática de recursos textuales que tratan sobre imágenes o cuando se requiere representar temáticamente a un recurso impreso conformado mayoritariamente por imágenes. Al dilucidar la práctica, en este segundo contexto, salen a flote circunstancias que conviene mencionar.

En el poema Junio, 1968, Borges ${ }^{12}$ enaltece la figura del bibliotecario al escribir "ordenar bibliotecas es ejercer de un modo silencioso el arte de la crítica". Este talento idealizado es menos realidad hoy en día cuando los procedimientos de catalogación por copia permean la actividad.

Cotidianamente el catalogador está habituado a dos prácticas, por un lado, reproducir lo que otro agente ya analizó previamente a través de la catalogación por copia, sin cuestionar sentido e interpretación de temas asignados, y sin realizar mayores adaptaciones que no se estipulen en las políticas locales

12 Jorge Luis Borges, Obras completas: 1952-1972, p. 376. 
de su institución. Si esta práctica no es posible, y se conjuga como determinante la productividad, la catalogación se realiza a partir de una lectura superficial de ciertos elementos, llamados por Genette, ${ }^{13}$ como paratextos que forman parte del umbral de un libro. Cuando el recurso a catalogar no cuenta con la estructura paratextual habitual se torna entonces en un objeto límite de conocimiento para el catalogador.

En definitiva, los catalogadores contamos con mejor preparación cuando se necesitan identificar fuentes de información textuales. Si una imagen no está acompañada de modulación paratextual que la describa explícitamente, nos encontramos con un obstáculo: no sabemos que podemos leerla, y tampoco conocemos métodos y herramientas para hacerlo. El viaje para comprenderla aparenta ser exclusivo para los acólitos de la imagen, por lo que cabe preguntar si analizar una imagen consiste en el desplazamiento a un lugar sagrado.

Existe una complejidad inherente en la definición clara de categorías visuales ¿cómo abordar su relación con los problemas terminológicos y de concepto sobre las distintas acepciones de imagen en cada lengua sin que esto afecte el proceso de análisis documental?.

En no pocas ocasiones nos encontramos en la encrucijada de servir a prescripciones normativas antes que al uso de términos bajo nuestra lengua. La labor de análisis documental está estrechamente condicionada por disposiciones que dictan herramientas convencionales, como la Lista de Encabezamientos de Materia de la Biblioteca del Congreso de E.U. (LCSH).

13 Aunque Genette se refiere a los textos literarios, se alude a la noción de paratextos que propone debido a que la mayoría de los libros cuentan con elementos textuales y gráficos que presentan a la obra a través de un umbral introductorio, editorial, organizativo, etcétera. Gérard Genette, Umbrales. 
Entre las disposiciones que afectan encontramos la aplicación canónica del principio de garantía literaria,${ }^{14}$ que genera dilemas al catalogador cuando requiere asignar términos que no forman parte de los catálogos de autoridad de temas y no se localizan en las fuentes predeterminadas a utilizar. Aunado a ello, las cortapisas para el análisis aumentan, al omitir los puntos de acceso por género o forma que podrían coadyuvar a una mejor comprensión de imágenes, dado que "es particularmente importante mantener la distinción entre el análisis de la materia (de lo que trata una obra) y del género/forma (lo que una obra es)". ${ }^{15}$ Cabe apuntar si se deberá al desconocimiento o desestimación de herramientas especializadas, ${ }^{16}$ que se representa a las imágenes contenidas en libros bajo el margen de actuación que los LCSH y su traducción al español permiten.

Las disposiciones no son las únicas determinantes, por lo que se vuelve relevante reflexionar sobre cuestiones inherentes a la complejidad de la lectura de imágenes. Entre los aspectos a

14 La garantía literaria es el principio que Wyndham Hulme creó en 1911, para legitimar el uso de términos en la clasificación y catalogación temática, bajo la consigna de que los términos tuviesen una amplia base de uso previamente establecida en publicaciones. M. Barité externa algunos cuestionamientos y replanteamientos que se han postulado a fin de entablar una apertura del principio más allá del propuesto originalmente por Hulme. Cfr. Mario Barité, Garantía literaria y normas para construcción de vocabularios controlados: aspectos epistemológicos y metodológicos, pp. 13-24.

15 Biblioteca Nacional de España, "Preguntas frecuentes FAQ sobre los términos género/forma de la Library of Congress para Bibliotecas y Material de Archivo".

16 Los avances en la traducción de herramientas esenciales redundaría en una mejor preparación para leer imágenes y llevar a cabo el análisis documental en nuestros ámbitos. Algunas de las herramientas que son difundidas abiertamente en el ámbito digital son:

Tesauro de Arte y Arquitectura, del Getty Research Institute, realizado por el Centro de Documentación de Bienes Patrimoniales de la Dirección de Bibliotecas, Archivos y Museos de Chile.

Tesauro para Materiales Gráficos de la Biblioteca del Congreso, a cargo de la Biblioteca Nacional de la República de Argentina, desde 2012. 
considerar están: la pertinencia de la interpretación, el carácter polisémico de las imágenes y el control que ejercen agentes externos sobre la manera de representar la cultura visual de nuestra región.

Dejando a un lado la complejidad inherente en el uso terminológico de cada lengua, el marco para facilitar la comprensión de la cultura visual de forma amplia por parte de los catalogadores, requiere de la intervención de prácticas encauzadas desde la perspectiva de la alfabetización visual. Como primer acercamiento basta con iniciar la experimentación de métodos de análisis que se instauran en los estudios visuales y disciplinas cuyo objeto de conocimiento son las imágenes.

En la selección de cualquier método es importante partir de las posibilidades que revela el carácter polisémico de las imágenes. Al respecto, Sontag, ${ }^{17}$ cuando analiza la polisemia en la fotografía, menciona que el objeto fotográfico cambia de acuerdo con el contexto donde se le ve, puede lucir diferente en un álbum, un archivo policial, una revista de fotografía o en un libro. Esos espacios de distribución sugieren un uso distinto y le añaden significados acotados a éste. Con ello, se genera un fenómeno de parcelamiento de la verdad en verdades relativas, que puede ser aceptado sin reservas en el contexto occidental, como se ha señalado en cuanto a la catalogación por copia.

Si imaginásemos un grabado que aún no ha pasado por el filtro de validación de la catalogación por copia ¿qué sucede cuando se mira desde la biblioteca?, ¿qué mira el que lo describe?, ¿se puede apreciar la meticulosidad que caracteriza al catalogador al describir físicamente un documento en la asignación de temas? En párrafos anteriores se mencionaron algunos aspectos y elementos generales que interceden en el aná-

17 Susan Sontag, Sobre la fotografía. 
lisis documental, y que consecuentemente llegan a hacerlo en el proceso de construcción de la interpretación. En definitiva, en tal punto interviene la mirada del sujeto que cataloga. Uno de los principios que debe regir a una disciplina, es el contraste de la información, por tanto, cabe preguntar ¿cómo se activa este principio en la mirada del catalogador a fin de evitar la tergiversación en la interpretación? .

En la segunda parte de este trabajo se aborda el caso concreto de análisis de una imagen que se descubrió a partir de una investigación sobre imágenes de bibliotecas. Al localizar un registro bibliográfico que describía el grabado de una "Biblioteca Palatina”, y después de observar detenidamente la composición gráfica, surgió el cuestionamiento sobre la fidelidad de la representación de la biblioteca. Se comparó la información que se indicaba en los encabezamientos de materia asignados y, a partir de ahí, germinó la duda sobre si la interpretación proporcionada en ellos era distorsionada o correcta su asignación.

Para contrastar la descripción en el registro se utilizó un método de análisis visual acorde al tipo de imagen y, posteriormente, se realizó la búsqueda de la misma imagen en otras colecciones, además de la indagación bibliográfica, para identificar posibles reproducciones adicionales. Es importante señalar que de antemano se considera la posibilidad de usos posteriores del mismo grabado pueden añadir otros significados, por lo que el análisis en el siguiente apartado, sea en el futuro una verdad relativa y acotada.

\section{PARTE II}

A continuación, en tres apartados, el análisis iconográfico que se realizó con base en el método iconológico de Panofsky, para 
identificar procedencia y tema de un grabado que forma parte de la colección digital Early English Books Online (EEBO).

El método consiste en aplicar tres niveles de análisis de una obra. El primero, es la descripción pre-iconográfica de formas presentes como objetos, acontecimientos, lugares; el siguiente, es el análisis iconográfico en el que se identifican temas y conceptos manifestados en imágenes, historias y alegorías y; el último, que corresponde a la interpretación iconológica, donde se buscan principios socioculturales subyacentes que parten del fundamento controlador de la interpretación, en el que se retoma "la historia de los síntomas culturales y de los símbolos para señalar el significado intrínseco o tema de la imagen". 18

Se determinó utilizar el método de Panofsky porque se adapta adecuadamente a la naturaleza de la imagen seleccionada. ${ }^{19}$

\section{ORIGEN DEL GRABADO BIBLIOTHECA}

\section{PALATINA}

Fue a partir de la descripción del grabado, en un catálogo de la British Library (véase figura 1), que se conoció de su existencia. La institución británica -como otras más en Europa- se ha nutrido de materiales diversos, recopilados de distinta procedencia, por lo que no era extraño observar que la descripción de la imagen fuera somera, y en cierta manera laxa, ya que se fechaba hacia 1600, como de autoría anónima y fragmento de una obra desconocida. En el registro bibliográfico no se indicaba el lugar de publicación, ni datos de imprenta. Y, en cuanto

18 Erwin Panofsky, Estudios sobre iconología, p. 25

19 Para la descripción, se dispuso exclusivamente de la digitalización de un microfilm del grabado. 
al tema, se le asignó el encabezamiento de materia: Bibliotheca Palatina (Biblioteca Apostólica Vaticana).

\section{Figura 1}

Registro bibliográfico del grabado Bibliotheca Palatina



Dado que existió una Biblioteca Palatina en Heidelberg, que fue obsequiada al Papa Gregorio XV e integrada en 1623 a la Biblioteca Apostólica Vaticana, no parecía incorrecto identificar al grabado como representación de tal biblioteca, pero las dificultades comenzaron al pretender leer la imagen como representación realista. Una vez que se comparó la información sobre la Biblioteca Apostólica Vaticana, se determinó que era muy 
distinta y no guardaba relación con las descripciones de ésta, ni con las características arquitectónicas de la Biblioteca Vaticana. ${ }^{20}$

Otro aspecto que despertaba dudas fue la información descrita en una nota del registro bibliográfico, en la que se indicaba que el grabado era el fragmento de una obra no identificada. Esto dio pauta para que a continuación se emprendiese una búsqueda en otros catálogos relacionados con la colección EEBO.

Con el beneficio de la información obtenida de las notas en otros registros bibliográficos, se verificó la existencia de un frontispicio con el título homónimo "Bibliotheca Palatina". De igual manera, fue invaluable la disponibilidad de la digitalización de ejemplares, en los que se encontró la reproducción del mismo grabado.

El grabado fue utilizado como frontispicio impreso de Linguce Latince liber dictionarius quadripartitus. A Latine dictionary, in four parts (véase figura 2). A diferencia del fragmento localizado anteriormente, al pie del frontispicio se encontró un texto manuscrito que incluía información específica sobre el grabado. En la recuperación de otras ediciones del diccionario, se identificó el mismo frontispicio en publicaciones de 1678 y 1684, y a partir de la edición de 1693, realizada por otros impresores, el grabado ya no acompaña a la obra.

20 Esta biblioteca se estableció en 1448, por fundación del Papa Nicolás V, y hacia 1587 el Papa Sixto V encargó al arquitecto Domenico Fontana construir una sede para la biblioteca que constaba de dos naves, con seis grandes pilares centrales. La biblioteca se encuentra en el Palacio Apostólico y se accede a ella a través del patio del Belvedere. Alfonso Muñoz Cosme, Los espacios del saber: historia de la arquitectura de las bibliotecas, p. 96. 
Figura 2

Frontispicio y portada en Adam Littleton, Linguæ Latinæ liber dictionarius quadripartitus. A Latine dictionary, in four parts (London: Printed for T. Basset ... J. Wright ... and R. Chiswell ..., 1678)

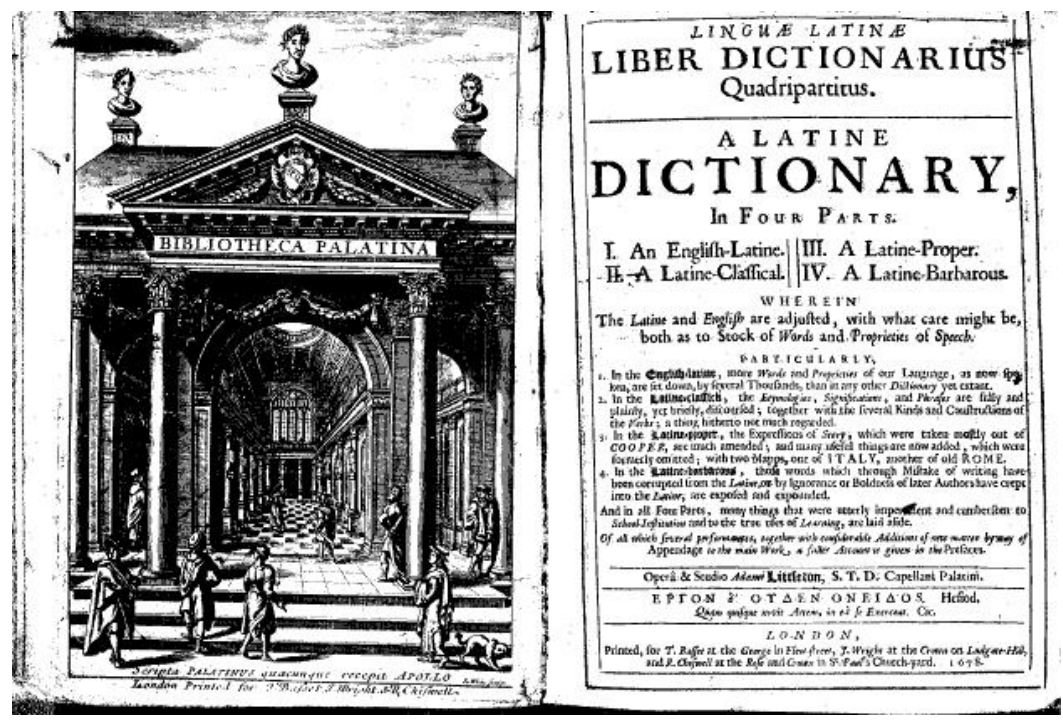

En los ejemplares de 1678 y 1684, el grabado incluye la firma del sculp, ${ }^{21}$ R. White. El nombre completo del grabador fue Robert White, de nacionalidad inglesa (1645-1703), quien fue conocido como pupilo de David Loggan. En sus primeros trabajos realizó dibujos y grabados con vistas arquitectónicas para frontispicios o portadas, ${ }^{22}$ y más adelante su obra se destacó por la calidad de la ejecución de retratos.

21 Sculp es una abreviatura de sculpsit. La palabra se agregaba al pie de un grabado después del nombre del grabador. William D. Whitney, ed., The Century dictionary and cyclopedia: a work of universal reference in all departments of knowledge with a new atlas of the world.

22 Entre sus obras se encuentra la portada para una edición en inglés de la Iliada profusamente ilustrada. 
Junto a la firma del sculp, al pie del frontispicio, hay una inscripción manuscrita que dice "Scripta PALATINUS quaecunque recepit APOLLO". Es una oración en latín que pudo ser tomada de las Epístolas de Horacio, ${ }^{23}$ y de la que se entiende "cualquier escrito que el Palatino Apolo haya acogido". 24

Al saber que el grabado formó parte de una publicación, acota en mayor medida su interpretación. De tal manera, se puede considerar que se trató de un encargo hecho por el impresor o el autor, para ser incluido como el frontispicio del diccionario de latín-inglés. Y si bien, en la fecha de edición de 1678, los ideales renacentistas ya no tenían la misma repercusión, en el grabado se identifica una anacrónica influencia renacentista.

\section{Descripción del grabado}

Se trata de la representación de un edificio monumental visto en perspectiva albertiana. En su fachada figura lo que se asemeja a un porche o detalle de un pórtico dístilo con frontón. El acceso se abre con una escalinata ancha y breve para dar la bienvenida y destacar la inscripción Bibliotheca Palatina en su friso. Arriba, en el frontón, se encuentra un medallón con las siglas SPQR -Senatus Populusque Romanus-, es decir, el Senado y el Pueblo Romano. Sobre la cima, se erige un busto

23 Puede tratarse de una cita tomada de las "Epístolas" que forma parte del fragmento del libro primero, tercera epístola, entre los versos 15 al 17:

"Quid mihi Celsus agit? Monitus multumque monendus, priuatas ut quaeret opes et tangere uitet scripta, Palatinus quaecumque recepit Apollo,"

24 La traducción es de Tarsicio Herrera Zapién, tomada de: Quinto Horacio Flaco, Epístolas I y II, p. 164. Para comprender el sentido original de la cita se reproduce la traducción del fragmento:

"¿Qué hace mi Celso? Ha sido exhortado y mucho hay que exhortarlo, a que busque riquezas propias y evite tocar

cualquier escrito que el Palatino Apolo haya acogido". 
de Augusto, y más atrás, en segundo orden, sobre el techo del edificio se hallan un busto a Cicerón y otro para Virgilio (véase figura 3).

El acceso se extiende sobre un corredor dispuesto a lo ancho del edificio para apreciar desde afuera el interior. El edificio se dibuja en tres naves, la nave central a modo de salón, y dos naves laterales con galerías más pequeñas. Antes de entrar, se puede distinguir que está adornado por una guirnalda que guía la vista hacía los arcos. En el interior, se duplica una columnata que sostiene una planta alta. Sobre las columnas se han colgado pequeños retratos o tal vez cartelas. Al fondo de esa planta, se ve un gran ventanal y sobre las paredes apenas se distingue adosada la estantería (véase figura 4). La vista se acompaña por figuras humanas con vestiduras renacentistas que -conforme a la perspectiva albertiana- se dibujan más grandes en las primeras cuatro braccias, y en las subsecuentes se hacen más pequeñas. Los personajes dibujados parecen pasear y contemplar la gran biblioteca, solo uno de ellos está absorto en el interior viendo una imagen o leyendo la cartela sobre una columna, mientras que al exterior del edificio, en el extremo derecho, un can parece salir de la escena. La sensación de espacio también lo configura el diseño de baldosas que nos guían al punto de fuga debajo del ventanal del fondo. Al mirar al interior del edificio, se observa el trazo de la bóveda de cañón casetonada y detalle de lo que parece ser una cúpula. 
Figura 3

Robert White, Bibliotheca Palatina, ca1678. Detalle superior del grabado

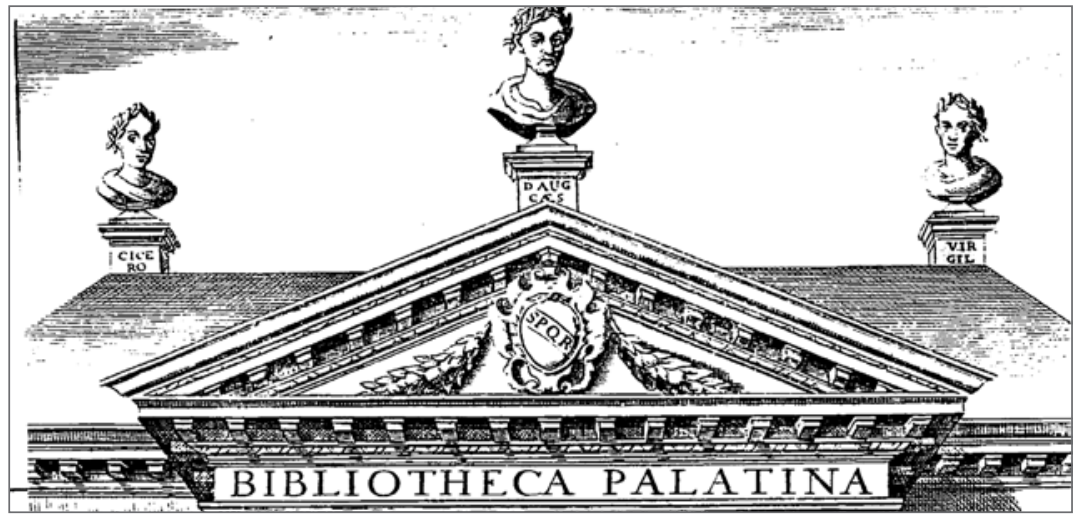

Figura 4

Robert White, Bibliotheca Palatina, ca1678. Detalle central del grabado

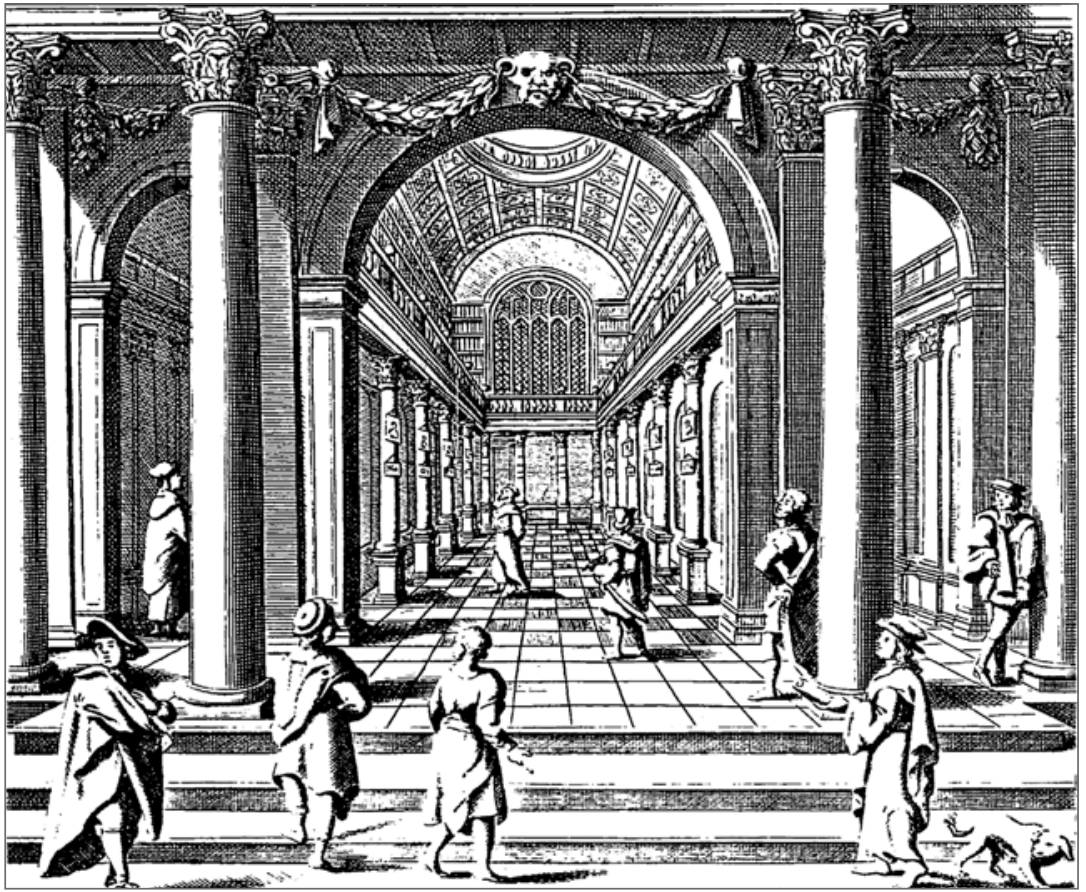




\section{Interpretación de la Bibliotheca Palatina}

Al tratarse de una imagen concebida para adornar el inicio de un diccionario de latín, no se encuentra discorde elevar la cultura clásica a través de la transmisión escrita, pues una biblioteca es el espacio en donde se ha concentrado y recuperado el saber clásico. Representarla como monumento enarbola el papel de la cultura escrita e ideales por el cultivo del hombre a través del conocimiento secular.

Cuando se observa en primer orden la referencia a Augusto, da la pauta a considerar que el grabado hace honor a las antiguas bibliotecas romanas. En especial a la Bibliotheca Apollinis Palatini o también llamada Bibliotheca Palatina, que el emperador mandó a construir en el Palatino; colina en Roma en la que se construyó un conjunto de edificios entre los que se encontraba el Templo de Apolo, pórticos y dos bibliotecas. En una de las bibliotecas se recopilaba la literatura griega y en la otra la literatura latina. La existencia de las bibliotecas se sabe en principio por autores como Ovidio, Horacio, Tácito. ${ }^{25}$ Por Plinio conocemos algunas de las características que señaló sobre las bibliotecas romanas:

Existe la costumbre de dedicar en las bibliotecas, si no en oro ni plata si por lo menos en bronce, los retratos de aquellos de los cuales nos hablan en estos mismos lugares las almas inmortales; más aún, se imaginan incluso los de aquellos que no existen, y se materializan, de acuerdo a los deseos, rostros de los cuales la tradición nos informa... ${ }^{26}$

25 Samuel Ball Platner, A topographical dictionary of ancient Rome, p. 84. También se hace recuento de las fuentes en: Alfonso Muñoz Cosme, Los espacios del saber: historia de la arquitectura de las bibliotecas, p. 36.

26 Cayo Plinio II, Historia natural: libro 35, p. 76. 
Las bibliotecas romanas como la del Palatino tenían una función pública, es por eso que la distinción del medallón, en el grabado de la Bibliotheca Palatina, homenajea al Senado y al Pueblo Romano. Otra manera de subrayar el carácter público, en la representación de White, es el hecho de que no se dibujen puertas, por lo que podría remitir a la alusión de un lugar abierto, que invita a entrar en él.

En definitiva, no debemos olvidar que una biblioteca ha significado símbolo de poder desde la antigüedad; y de forma notable los vestigios e ideas sobre el Imperio Romano que, en fuentes clásicas y descubiertas en distintos momentos, influyeron en las ideas futuras sobre las bibliotecas. La monumentalidad de las bibliotecas renacentistas, como la Vaticana, Marciana, Laurenziana, Ambrosiana, la del Escorial, entre otras, fueron a su vez modelo para las concepciones y construcciones posteriores durante los siglos XVII y XVIII. En 1627, Gabriel Naudé en su Advis pour dresser une Bibliothèque, menciona que no existe "ningún otro medio más honesto y certero para adquirir un gran renombre entre los pueblos que levantar bellas y magníficas bibliotecas dedicadas al uso del público". ${ }^{27}$

No obstante, el grabado tampoco es una representación realista de la biblioteca latina, pues los restos arqueológicos del Palatino fueron descubiertos en distintas épocas. Con la recuperación paulatina de los fragmentos del Forma Urbis Romae, ${ }^{28}$ a partir de 1562, se enriquecería el conocimiento de la complejidad arqueológica alrededor del Templo Apolo en el Palatino, pero el emplazamiento urbanístico de la Roma antigua no puede prescindir a la vez de datos que proveen las fuentes

27 Gabriel Naudé, Recomendaciones para formar una biblioteca, p. 12.

28 El Forma Urbis Romae es un mapa hecho de mármol que representaba a la ciudad de Roma. Fue esculpido entre 203-211 A.D. Solo se conservan fragmentos del mapa. 
literarias. Las reconstrucciones, a partir del estudio de fuentes y comparación con el conocimiento arqueológico, sólo pueden dar una idea parcial de cómo era la biblioteca. Las hipótesis de la composición arquitectónica ${ }^{29}$ indican que la biblioteca de Augusto estaba formada por dos salones absidales, puestos lado a lado con columnas a lo largo de las paredes curvas.

Es más viable pensar que se trata de una composición en donde el sculp R. White, fusiona la idea de la biblioteca pública romana con remembranzas a bibliotecas monumentales renacentistas, pues integra elementos arquitectónicos como la planta tipo salón, así como la decoración de la biblioteca con inscripciones, esculturas, medallones y retratos, para aludir a la cultura latina desde una valoración con influencia renacentista.

Cabe proponer que la función del grabado fuese de carácter emblemático, en tanto si se manifiesta que su uso, a modo de imagen "llevó a ilustrar libros de autores clásicos con emblemas expresamente [...] grabados para alegorizar determinadas abstracciones, ideas o hechos que destacan a lo largo del texto". ${ }^{30}$ En este caso, se rememora la cultura latina usando como emblema a la biblioteca, y representándose con elementos arquitectónicos.

Otros aspectos que se podrían considerar, son las referencias coétaneas sobre bibliotecas europeas o británicas: saber de tendencias constructivas que se mostraban hacia mediados del siglo XVII, o la misma circulación de imágenes sobre bibliotecas que llegaban a Londres por influencia italiana, ${ }^{31}$ para

29 Samuel Ball Platner, The topography and monuments of ancient Rome, p. 162 .

30 Juan Eduardo Cirlot, Diccionario de símbolos, p. 187.

31 Cfr. Capítulo 8 y 9 de Alfonso Muñoz Cosme, Los espacios del saber: historia de la arquitectura de las bibliotecas. 
determinar las posibles influencias que motivaron a White a representar de esa manera a la biblioteca. Melot ${ }^{32}$ menciona que no es sino hasta el siglo XVII, cuando se empieza a hablar de bibliotecas como edificios específicos.

Vale la pena mencionar lo que no se muestra en el grabado: en otras representaciones producidas en el siglo XVII, algunas bibliotecas se dibujaron sin muebles, pupitres, facistoles o atriles. La vacuidad de la galería enfatizaba la perspectiva en sí misma, y eliminaba posibles distracciones en la observación de detalles.

No deja de llamar la atención el anacronismo entre la época en que nacieron los ideales renacentistas, a los que se refirieron como posible influencia en la producción del grabado, y la fecha en que fue creada la obra, pero parece que en el contexto de un diccionario de latín no está fuera de lugar crear una relación a partir del motif de la biblioteca. Algunos de los implicados, sea el grabador R. White, el autor del diccionario, Adam Littleton, o los impresores, quisieron un frontispicio que representase a la Bibliotheca Palatina y, a la vez, a manera de emblema, aludir a la cultura latina.

La aplicación del método de Panofsky guió, por la vía adecuada, el leer el tipo de imagen presentada aquí, sin embargo, queda por resolver si se usó, en otro contexto fuera de su complementariedad, como frontispicio de un libro. Es importante recordar que el primer ejemplar del que partió la investigación, no contaba con elementos paratextuales, como sucede con la imagen del frontispicio.

32 Michel Melot, La sabiduría del bibliotecario, p. 57. 


\section{CONSIDERACIONES FINALES}

Recapitulando, el análisis que se presentó está configurado de forma sistemática. Inició con la identificación de la obra, lo que implicó investigación bibliográfica y, consecuentemente, obtener familiaridad con fuentes literarias. La descripción del grabado no requirió más que del saber cotidiano, es decir, familiaridad con objetos, formas, acciones y lograr enunciar la composición bajo la observación, sin connotaciones, pero considerando condiciones históricas que determinan la existencia de dichos elementos. En última instancia, con el contexto adecuado, sobre lo que se miró y observó, se interpreta la representación.

Por lo tanto, al comparar el resultado del análisis con la catalogación temática del grabado registrada en la British Library, se infiere que tuvo lugar un efecto de sobre-interpretación, sin distinguir en la observación directa de la imagen alguna de las características que la misma aporta para su identificación. Se confió en el conocimiento práctico de la existencia aparente de una sola Bibliotheca Palatina y, con lo cual, se manifestó una distorsión cognitiva.

La intención de presentar este análisis es ejemplificar y senalar que al mirar una imagen se ven implicados varios modos de interpretación, en los que la conjugación de la polisemia y mirada subjetiva, pueden generar la distorsión cognitiva que acarree la errónea identificación de una obra. El grabado, que continúa descrito en el catálogo con el encabezamiento de materia Bibliotheca Palatina (Biblioteca Apostólica Vaticana), lo podemos considerar como vestigio de formas en que los catalogadores limitamos la comprensión de las imágenes.

Cabe preguntar, si como disciplina, la bibliotecología es parte de los últimos humanistas que peregrinan con el báculo textual en un mundo donde se afianzan paradigmas que la cultura visual está instaurando. 
Hoy en día irrumpen nuevas formas de analizar imágenes con menor intermediación textual. Existen múltiples aplicaciones tecnológicas que recurren a sistemas de Content-based Image Retrieval para erradicar las limitaciones de intermediación textual en bases de datos de imágenes. Como ejemplo, desde 2003, el State Hermitage Museum de St. Petersburgo utiliza una aplicación de IBM, para ofrecer de forma conjunta la búsqueda basada en colores y formas, además con intermediación textual que incluye la descripción de estilos, género, tema, artista, título, etcétera.

Aún con los avances tecnológicos, es difícil no dar crédito a la intermediación textual a través de lenguajes documentales, como encabezamientos de materia, pero si la intermediación textual prosigue como técnica, en el contexto documental bibliotecario, es igual de necesario no desdeñar otras formas de análisis de imágenes, ya sea que radiquen de paradigmas divergentes, llámense semánticos, formales, histórico-social o iconológico, como el mostrado aquí. Es relevante para la disciplina inducir a segundo plano la idea de oposición binaria texto/imagen, para dar paso a un nuevo estadio en bibliotecología, de tal forma, que no seamos considerados como el grupo de los últimos humanistas que forman parte de la categoría de especialistas, cuya posición de poder distorsiona el saber de las imágenes.

Por largo tiempo, el pensamiento práctico ha caracterizado la formación y actuación profesional de aquellos que apuestan por la bibliotecología como el medio para interactuar con la sociedad. La búsqueda de soluciones ha llegado a ser aspecto que asedia constantemente las actividades bibliotecarias. En buena medida, la historia disciplinar refleja que, parte de las preocupaciones primarias, se concentraron en grandes temas relativos a organización y, en el objetivo ulterior, de saber cómo hacerlo. Basta observar que mientras los objetos de informa- 
ción registrada fueron estables, se obtuvo un avance y pericia porque se les conocía completamente. Pero el arribo intermitente de otros escenarios de producción pertenecientes a objetos de información registrada, puso a prueba la experiencia disciplinar para organizarlos. Si enfocamos el panorama hacia las manifestaciones visuales, se observa que éstas se encuentran en singular punto de intersección, como objeto límite de conocimiento dado, que se valoran a través del pensamiento práctico casi exclusivamente.

La razón por la que no ha trascendido el conocimiento de las imágenes, aún con la existencia de la noción de su tratamiento documental, reside en el arraigo de la distorsión cognitiva que mueve a la disciplina. No han llegado a cimbrar reflexiones importantes generadas desde la filosofía, los estudios culturales, la sociología, la psicología y la semiótica, entre otros campos, de los que, cabe subrayar, las imágenes como objetos de estudio tampoco fueron inmanentes a éstas.

\section{BIBLIOGRAFÍA}

Adorno, Rolena, Guaman Poma y su crónica ilustrada del Perú colonial: un siglo de investigaciones hacia una nueva era de lectura, traducción de Fernanda Macchi Dinamarca, Det Kongelige Bibliotek, 2010.

Barité, Mario, "Garantía literaria y normas para construcción de vocabularios controlados: aspectos epistemológicos y metodológicos”, en Scire, núm. 15, jul.-dic., 2009, pp. 13-24.

Biblioteca Nacional de España, "Preguntas frecuentes FAQ sobre los términos género/forma de la Library of Congress para Bibliotecas y Material de Archivo". http://www.loc. gov/catdir/cpso/genre_form_faq_spanish.pdf (Consultado el 6-8-2013). 
Borges, Jorge Luis, Obras completas: 1952-1972, Barcelona, Emecé, 1997.

Burke, Peter, El Renacimiento, Barcelona, Crítica, 1993.

Cayo Plinio II, Historia natural, Madrid, Gredos, 2003.

Cirlot, Juan Eduardo, Diccionario de símbolos, Madrid, Ediciones Siruela, 2008.

Cragoe, Carol Davidson, Cómo leer edificios: un curso rápido sobre estilos arquitectónicos, Barcelona, Blume, 2013.

Flor, Fernando R. de la, Giro visual: primacía de la imagen y declive de la lecto-escritura en la cultura postmoderna, Salamanca, Editorial Delirio, 2009.

Genette, Gérard, Umbrales, México, Siglo XXI, 2001.

Guaman Poma de Ayala, Felipe, El primer y nveva corónica $i$ bven gobierno, (1615/1616) (København, Det Kongelige Bibliotek, Ms. GKS $22324^{\circ}$ ) http://www.kb.dk/permalink/2006/poma/info/en/frontpage.htm

Littleton, Adam, Linguae Latinae liber dictionarius quadripartitus A Latine dictionary in four parts: I. An English-Latine, II. A Latine-classical, III. A Latine-proper, IV. A Latine-barbarous: wherein the Latine and English are adjusted, with what care might be, both as to stock of words and proprieties of speech ... / operâ \& studio Adami Littleton, London, Printed for T. Basset J. Wright and R. Chiswell, 1678. Ejemplar: Wing/L2563. http://gateway.proquest.com/openurl?ctx_ ver=Z39.88-2003\&res_id=xri:eebo\&rft_ $\mathrm{id}=x$ ri:eebo:citation: 18648772 .

Littleton, Adam, Linguce Latince liber dictionarius quadripartitus. A Latine dictionary, in four parts, London, for T. Basset at the George in Fleet-street, J. Wright at the Crown on Ludgate-Hill, and R. Chiswell at the Rose and Crown in St. Paul's Church-yard, 1684. Ejemplar: Wing/L2564. 
http://gateway.proquest.com/openurl?ctx_ver=Z39.882003\&res_id=xri:eebo\&rft_id=xri:eebo:image:108105

Littleton, Adam, Linguae latinae liber dictionarius quadripartitus. Dr. Adam Littleton's Latine dictionary, in four parts, London, Printed for W. Rawlins, R. Chiswel, C. Harper, S. Sprint, J. Place, D. Midwinter, and T. Leigh, 1703. Ejemplar: Tract Supplement/E3:2[161]. http://gateway.proquest.com/ openurl?ctx_ver=Z39.88-2003\&res_id=xri:eebo\&rft_ id=xri:eebo:citation:99895053

Maier, Michel, Atalanta fugiens, Oppenheimii, Ex tipographia Hieronymi Galleri, 1617.

Melot, Michel, La sabiduría del bibliotecario, Vitoria-Gasteiz, Eusko Jaurlaritza Argitalpen Zerbitzu Nagasia, 2005.

Mirzoeff, Nicholas, Una introducción a la cultura visual, Barcelona, Paidós, 2003.

Mitchell, W. T. J., Teoría de la imagen, Madrid, Akal, 2009.

Muñoz Cosme, Alfonso, Los espacios del saber: historia de la arquitectura de las bibliotecas, Gijón, Ediciones Trea, 2004.

Naudé, Gabriel, Recomendaciones para formar una bibliote$c a$, prólogo, traducción y notas de Evaristo Álvarez Muñoz, Oviedo, Krk, 2008.

Otlet, Paul, El tratado de documentación: el libro sobre el libro: teoría y práctica, trad., María Dolores Ayuso García, Murcia, Universidad de Murcia, 2007.

Panofsky, Erwin, Estudios sobre iconología, Madrid, Alianza, 2008.

Pasquel, Elda, Textos sobre el Renacimiento, México, UIA, 1996.

Phillipot, Clive, Booktrek: selected essays on artists' books since 1972, Zürich, JRP Ringier Kunstverlag, 2013. 
Platner, Samuel Ball, The topography and monuments of ancient Rome, Boston, Allyin and Bacon, 1911.

Platner, Samuel Ball and revised by Thomas Ashby, A topographical dictionary of ancient Rome, London, Oxford University Press, 1929. http://penelope.uchicago.edu/Thayer/ E/Gazetteer/Places/Europe/Italy/Lazio/Roma/Rome/_Texts/ PLATOP*/home.html

Quinto Horacio Flaco, Epístolas I y II, México, UNAM, 1986.

Registro Bibliográfico del grabado Bibliotheca Palatina. Disponible en: http://gateway.proquest.com/openurl? ctx ver= Z39.88-2003\&res_id=xri: eebo\&rft_id=xri:eebo: citation:226318103

Ruscha, Edward, Edward Ruscha Editions, Engberg, Phillpot: Walker Art Center, 1999, 2 vols.

- - , Twentysix Gasoline Stations, Alhambra, California, National Excelsior Press, 1963.

Sontag, Susan, Sobre la fotografía, trad., de Carlos Gardini, Barcelona, Debolsillo, 2010.

Whitney, William D., ed., The Century dictionary and cyclopedia: a work of universal reference in all departments of knowledge with a new atlas of the world, New York, The Century Co., 1902.

White, Robert. Disponible en: https://www.lib.rochester.edu/ index.cfm?PAGE $=4130$ 


\title{
Epílogo
}

\author{
CATAlina PÉREZ MELÉNDEZ
}

Dirección General de Bibliotecas de la UNAM

\section{MANIFIESTO BIBLIOTECÓlOGOS ICONÓFILOS}

A las multitudes pensantes y futuros biblis...

¿Están cansados de que no se estudien las manifestaciones visuales desde la Bibliotecología ... en México?

Bibliotecológos Iconófilos se harán llamar aquellos que compartan el placer por contemplar a las imágenes, por escudrinarlas con ojo pensante más allá de los límites que se han impuesto en la disciplina.

Los Bibliotecológos Iconófilos se comprometerán a viajar más allá de lo que la wikipedia pueda decir y transgredir las fronteras de lo que google imágenes pueda ofrecer. 
Los Bibliotecológos Iconófilos entenderán que el modelo FRBR en el futuro puede ser caduco y por lo tanto contrastarán lo que otras comunidades tienen que decir $y$ ofrecer sobre el análisis de las imágenes.

Los Bibliotecológos Iconófilos fomentarán la discusión sobre las aberraciones interpretativas que se generan con el uso de los encabezamientos de materia.

Los Bibliotecológos Iconófilos propiciarán la lectura de la imagen en términos igualitarios e interactuantes con la lectura de la palabra escrita.

Los Bibliotecológos Iconófilos completarán con sus propias ideas e imaginación este manifiesto...

¡Viva la imagen y su lectura! 
El giro visual en bibliotecología: intersecciones de la información, la imagen y el conocimiento. Coordinación editorial, Carlos Ceballos Sosa; revisión y evaluación editorial, Aurea Gabriela Mondragón Pérez; revisión especializada, formación editorial y revisión de pruebas, Editorial Albatros, S.A. de C.V. Instituto de Investigaciones Bibliotecológicas y de la información / UNAM. Se terminó de producir en Ciudad Universitaria, México. D. F. en el mes de noviembre de 2014. 